\title{
Experimental constraints on the evolution of organic matter in oil shales during heating: Implications for enhanced in situ oil recovery from oil shales
}

DOI:

10.1016/j.fuel.2019.116412

\section{Document Version}

Accepted author manuscript

Link to publication record in Manchester Research Explorer

Citation for published version (APA):

Sun, P., Yu, F., Zhao, K., Ma, L., \& Tian, X. (2020). Experimental constraints on the evolution of organic matter in oil shales during heating: Implications for enhanced in situ oil recovery from oil shales. Fuel, 261.

https://doi.org/10.1016/j.fuel.2019.116412

\section{Published in:}

Fuel

\section{Citing this paper}

Please note that where the full-text provided on Manchester Research Explorer is the Author Accepted Manuscript or Proof version this may differ from the final Published version. If citing, it is advised that you check and use the publisher's definitive version.

\section{General rights}

Copyright and moral rights for the publications made accessible in the Research Explorer are retained by the authors and/or other copyright owners and it is a condition of accessing publications that users recognise and abide by the legal requirements associated with these rights.

\section{Takedown policy}

If you believe that this document breaches copyright please refer to the University of Manchester's Takedown Procedures [http://man.ac.uk/04Y6Bo] or contact uml.scholarlycommunications@manchester.ac.uk providing relevant details, so we can investigate your claim.

\section{OPEN ACCESS}


Elsevier Editorial System(tm) for Fuel Manuscript Draft

Manuscript Number: JFUE-D-19-02125R2

Title: Experimental constraints on the evolution of organic matter in oil shales during heating: implications for enhanced in situ oil recovery from oil shales

Article Type: Research Paper

Keywords: oil shale; heating experiments; released products; organic matter; thermal evolution; in situ conversion

Corresponding Author: Dr. Pingchang Sun, PHD

Corresponding Author's Institution: Jilin University

First Author: Fengning Yu

Order of Authors: Fengning Yu; Pingchang Sun, PHD; Kang'an Zhao; Lin Ma; Xuemei Tian

Abstract: In situ oil shale conversion experiments have revealed that to efficiently obtain shale oil, factors such as heating temperature, products, and matter thermal evolution of organic matter during heating need to be optimized. In this study, oil shales from China were subjected to retorting experiments involving eight heating steps. During steps I-II $\left(\leq 300^{\circ} \mathrm{C}\right)$, the expelled product is mainly water, the hydrocarbon generation potential (PP) of the samples was extremely high, and the organic matter was in the immature to low-mature stage. The oil shale produced a large amount of oil in steps III-VI $\left(300-475^{\circ} \mathrm{C}\right)$, and the TOC contents and $\mathrm{S} 2$ of the shale showed the greatest decreases during these steps. The analysis data suggest that the organic matter entered the mature stage during these steps. After heating to $400^{\circ} \mathrm{C}$ and expelling a large amount of oil and gas, the PP decreased gradually. From 475 to $520^{\circ} \mathrm{C}$ (steps VII-VIII), only a small amount of gas was produced and the organic matter had almost no PP in the high- and over-mature stages. Based on our experimental results, in situ conversion of oil shale the final heating temperature should be $\sim 40^{\circ} \mathrm{C}$. These constraints require further field testing to be properly optimized. 
Dr. Pingchang SUN

College of Earth Sciences,

Jilin University,

Changchun 130061,

P.R. China

Tel: 0086 13674313295, Fax: 0086431 88502603,

E-mail: sunpingchang711@ @ 126.com

To the editors of

Fuel

Re: Manuscript: " Reveal the evolution of organic matter in heating oil shale——Preliminary exploration of oil shale in-situ conversion model"

Dear Editors,

We would like to submit the manuscript "Reveal the evolution of organic matter in heating oil shale - Preliminary exploration of oil shale in-situ conversion model" to the Fuel. The authors are: Fengning Yu, Pingchang Sun", Kang'an Zhao, Lin Ma and Xuemei Tian

Thank you for your support.

Yours sincerely,

Pingchang Sun 


\section{Specific responses to the issues}

Dear reviewers and editor,

Thank you for your valuable comments and suggestions on our article. All changes in the manuscript have been highlighted in yellow. In the following, we explain how and where the reviewers' comments have been addressed.

We hope that the manuscript is acceptable in its revised form.

Yours sincerely,

\section{Reviewer 1}

\section{Issue 1:}

As far as I know, in-situ heating is a low-temperature and a long-term heating process carried out underground, and the short-time high-temperature thermal simulation in the open system used in this paper directly determines the underground conditions needs to be considered.

The heating temperature is $<600^{\circ} \mathrm{C}$, which is low-temperature retorting. The maximum heating temperature in our experiments is $520^{\circ} \mathrm{C}$, which is similar to the insitu conversion temperature of oil shale in China, and is also low-temperature retorting. In situ oil shale conversion technology in China has produced a large amount of oil and gas in a short time. Therefore, we consider that our experiments are relevant to in situ conversion of oil shale. However, in situ oil shale conversion technology in China still needs to be improved and perfected. Our work also needs to be modified according to future in situ experimental results.

\section{Issue 2:}

The most important part of the thermal simulation experiment is the choice of the heating temperature range and the heating rate. Does the text only mention whether following the Chinese Petroleum Chemical Industry Standard SH/T0508-92 appears to be insufficient? 
In view of the small sample sizes, the heating time was very short. The test results showed that, according to the heating temperature and time, hydrocarbons were completely discharged in the final heating stage. However, for actual in situ oil shale conversion, the geological body is very large, and the heating time and rate are different to those in our test. Our experiments are only preliminary, and the heating rate and temperature require further investigation. The reason for choosing the Chinese Petroleum Chemical Industry Standard SH/T0508-92 is that this heating mode has been established by Fushun Mining Company based on thousands of experiments at different heating rates and temperatures. However, study of different heating rates and temperatures will be a focus of later research.

\section{Issue 3:}

Different heating rates and heating times directly affect the oil-producing characteristics of oil shale. Whether to consider the influence of different heating rates on the oil-producing characteristics and determine the optimum temperature. Although, when determining the optimal temperature, there is no mention of the relationship between the amount of oil produced and the heating cost. I don't think this is appropriate.

As noted above, our experiments are only preliminary, and in the future it will be necessary to carry out laboratory simulations guided by a model of ground retorting, which can examine the thermal evolution of organic matter. The optimum heating temperature obtained from our experiment is also a preliminary constraint. However, a pilot study of in situ oil shale conversion in China will also use a heating temperature of $>450^{\circ} \mathrm{C}$ (even $600^{\circ} \mathrm{C}$ to $700{ }^{\circ} \mathrm{C}$ ). This pilot study may further improve our heating model. We consider that it is too early to discuss the economic viability of in situ oil shale production prior to the pilot test.

\section{Issue 4:}

This paper concludes that during the heating interval, the oil gradually changed from a low-viscosity liquid to a high-viscosity semi-liquid. As far as I know, this article did not study the crude oil components produced by the experiment, so how to prove such a conclusion?

In our experiment, the occurrence of oil-water separation meant that xylene was used to completely dissolve the oil. After the water content was obtained, the mixture of xylene and oil was treated as waste liquid. The viscosity of the crude oil is based primarily on the fluidity of the oil produced during the low-temperature retorting 
process. The low-temperature retorting furnace (Fig. 2) also results in distillation. With increasing temperature, the crude oil components with a high boiling point are gradually gasified, discharged, and condensed in the receiver. Therefore, the viscosity of the crude oil increased gradually with increasing temperature.

\section{Issue 5:}

This paper suggested that water in oil shale should be fully removed by heating to $300^{\circ} \mathrm{C}$. Do you consider the energy consumption and environmental issues of heating and water removal?

The in situ oil-shale conversation experiment by Jilin University was unsuccessful until the water had been removed from the water-rich oil shale. In our paper, we note that oil shale with a high water content should be dehydrated before heating to $300^{\circ} \mathrm{C}$. During heating, the water is gasified and can be discharged in the recovery wells. This process does not consume much energy. At present, the rocks above and below the oil shales in the Songliao Basin are dense and unfractured mudstones, which effectively prevent oil-bearing fluid from escaping. Since the in situ conversions began 3-4 years ago, there have been no environmental problems, but this needs to be closely monitored in the future.

\section{Issue 6:}

There are still many errors in the language expression of this article. Please check and modify it carefully.

Our manuscript has been edited by Stallard Scientific Editing and a professional native speaker.

\section{Reviewer 2}

Issue 1:

Although some figures are still not clear, I think it can be published.

Thank you for your approval and suggestions.

\section{Reviewer 3}




\section{Issue1:}

Author revised most of issues according to advice, therefore, no more questions.

Thank you for your approval and suggestions. 


\section{Highlights:}

- Organic matter thermal evolution was revealed

- Retorting products diversity in different heating steps

- Final heating temperature was suggested in situ conversion of oil shale

- Accumulation sequence of unconventional energy sources was simulated 


\section{Experimental constraints on the evolution of organic matter in oil} shales during heating: implications for enhanced in situ oil recovery from oil shales

\footnotetext{
Fengning $\mathrm{Yu}^{1,2}$, Pingchang Sun ${ }^{1,2^{*}}$, Kang'an Zhao ${ }^{1,2}$, Lin Ma ${ }^{3}$, Xuemei Tian ${ }^{4}$

1. College of Earth Sciences, Jilin University, Changchun, Jilin 130061, China

2. Key-Lab for Oil Shale and Paragenetic Minerals of Jilin Province, Changchun, Jilin 130061, China

3. School of Earth and Environmental Sciences, The University of Manchester, Manchester, M13 9PL, UK

4. College of Education Science, Jilin Normal University, Siping, Jilin 136000, China
}

*Corresponding author: College of Earth Sciences, Jilin University, Jianshe str. 2199,

Changchun 130061, China.

Tel.: 008613674313295

Fax.: 008643188502603

E-mail addresses: sunpingchang711@126.com 
Abstract: Oil shale resources are an important unconventional global petroleum resource, although in situ conversion of organic matter to hydrocarbons is necessary for future effective exploitation of oil shale. A number of in situ oil shale conversion experiments have revealed that to efficiently obtain shale oil, factors such as the heating temperature, products of the heated oil shale, and thermal evolution of organic matter during heating need to be optimized. In this study, oil shales from the Minhe, Junggar, and Longkou basins of China were subjected to low-temperature carbonization experiments involving eight heating steps, with total organic carbon (TOC) analysis, rock pyrolysis analysis, microscopic observations, and oil shale (semi-coke) analysis after each step. During heating from room temperature to $300^{\circ} \mathrm{C}$ (steps I-II), the expelled product is mainly water, the hydrocarbon generation potential of the samples was extremely high, and the organic matter was in the immature to low-mature stage. With increasing temperature, the amount of oil produced from the oil shale gradually increased. The oil shale produced a large amount of oil in steps III-VI $\left(300-475^{\circ} \mathrm{C}\right)$, and the TOC contents and remaining hydrocarbon generation potential $\left(\mathrm{S}_{2}\right)$ of the shale showed the greatest decreases during these steps. This temperature range is the oil window for rapidly heated oil shale at low pressures. The geochemical and organic matter fluorescence data suggest that the organic matter entered the mature stage during these steps. After heating to $400^{\circ} \mathrm{C}$ and expelling a large amount of oil and gas, the hydrocarbon generation potential decreased gradually. The maximum $S_{1}$ (free oil) value is considered to be the extraction limit of oil and gas in this experiment, which is much higher for type I than type II kerogen oil shale. From 475 to $520^{\circ} \mathrm{C}$ (steps VII-VIII), only a small amount of gas was produced and the organic matter had almost no hydrocarbon generation potential in the high- and over-mature stages. However, there was still some residual carbon in the semi-coke after the final heating step. Our experiments mimic the transformation of oil shale to shale oil and gas, and to shale gas accumulation during the thermal evolution of organic matter. Based on our experimental results, in situ conversion of oil shale should first remove water by heating to $300^{\circ} \mathrm{C}$, and then the final heating temperature should be $\sim 440^{\circ} \mathrm{C}$ (but slightly higher for oil shale containing type I kerogen). These constraints require further field testing to be properly optimized.

Keywords: oil shale; heating experiments; released products; organic matter; thermal evolution; in situ conversion 


\section{Introduction}

Oil shale is an important unconventional energy source with estimated global in situ resource of $411 \times 10^{9} \mathrm{t}$. As such, oil shale research and exploration have become important in many countries [1]. At present, the main use of oil shale is in surface retorting and electricity generation, although numerous advances have been made in the further utilization of oil shales [2-5] .

Numerous studies have investigated the effects of heating temperature and rate, and particle size, on oil yield, gas evolution, shale oil composition, and oil shale pyrolysis, porosity, and permeability during retorting [6-15]. These results have been important in guiding the efficient use of oil shale. There are some environmental problems related to oil shale surface retorting, such as water-air pollution and waste residue stacking, which restrict the large-scale use of oil shale resources. Therefore, numerous pilot in situ conversion experiments on oil shale have been carried out [16-19], such as the Shell Company In Situ Conversion Process (ICP) [20-21], the Exxon Mobil Electrofrac $^{\mathrm{TM}}$ technology[22], and the Occidental modified in situ (MIS) technology [23-26] . In China, the technologies for on-site in situ conversion experiments on oil shale have been developed by the Zhongcheng Group and Jilin University, which have led to favourable outcomes [27-28] .

In situ conversion experiments on oil shale have focused on the heating technology, fracturing and sealing of the oil shale layer, and reservoir properties. However, during in situ heating the thermal evolution of organic matter and hydrocarbon generation and expulsion characteristics are also important in the efficient development and utilization of oil shale. To investigate this further, we conducted heating experiments on oil shales. Our experiments identified the heating required to reach the oil generation window and constrain the evolution of organic matter and hydrocarbon generation potential of oil shale when it is heated rapidly at atmospheric pressure. These results might guide the heating strategies of future pilot experiments designed to optimize the recovery and utilization of products produced by in situ conversion of oil shale.

\section{Samples and methods}

Three fine-grained oil shale samples formed the basis of this study. These samples are from the Minhe (Gansu Province, northwestern China) [28] , Junggar (Xinjiang Uygur Autonomous Region, northwestern China) [29], and Longkou basins (Shandong Province, east China) [30] , which are currently under development. Oil shales in the Minhe Basin occur mainly in the Middle Jurassic Yaojie Formation, and are well-bedded and greyish brown in colour. Oil shales in the Longkou Basin are mainly present in the Palaeogene Lijiaya Formation. The Longkou oil shales are 
well-bedded and brown in colour. Oil shales in the Junggar Basin are found in the upper Permian Lucaogou Formation, and are well-bedded and black in colour. One high-quality (i.e., high oil yield) sample of oil shale from each basin was selected for experimental heating and analysis.

The low-temperature step-heating experiments, total organic carbon (TOC) analyses, Rock-Eval pyrolysis analyses, organic maceral microscopic observations, and vitrinite reflectance determinations (Ro) were undertaken in the Key Laboratory for Oil Shale and Paragenetic Minerals of Jilin Province, Changchun, China. Oil shale samples (particles size less than $1 \mathrm{~cm}$ ) were heated in a low-temperature furnace in eight steps in dry open system (Fig. 1): room temperature to $185^{\circ} \mathrm{C}$ (I), $185-300^{\circ} \mathrm{C}$ (II), $300-350^{\circ} \mathrm{C}$ (III), $350-400^{\circ} \mathrm{C}$ (IV), $400-440^{\circ} \mathrm{C}$ (V), $440-475^{\circ} \mathrm{C}$ (VI), $475-500^{\circ} \mathrm{C}$ (VII), and $500-520^{\circ} \mathrm{C}$ (VIII). For each heating step, the samples were heated at a rate of $10^{\circ} \mathrm{C} / \mathrm{min}$, and then held at each temperature step for $30 \mathrm{~min}$.

TOC contents were determined using a LECO CS-230 instrument and Rock-Eval pyrolysis was carried out with a Rock-Eval 6 instrument following standard procedures [31]. The TOC contents and pyrolysis parameters were used to calculate the HI $\left(\mathrm{S}_{2} / \mathrm{TOC} \times 100\right)$ and OI $\left(\mathrm{S}_{3} / \mathrm{TOC} \times 100\right)$ values. Organic macerals were observed in polished blocks of whole-rock samples cut perpendicular to bedding planes using a Zeiss Axio Scope A1 microscope under reflected white and UV light (fluorescence). A small number of desmocollinite macerals $(\sim 20)$ were subjected to Ro measurements using the same instrument equipped with a microphotometer and under reflected white light.

\section{Results}

\subsection{Effects of low-temperature heating}

The three samples of oil shale underwent three distinct stages during heating: (1) steps I-II (room temperature to $\left.300^{\circ} \mathrm{C}\right)$; 2 . steps III-VI $\left(300-475^{\circ} \mathrm{C}\right)$; 3. steps VII-VIII $\left(475-520^{\circ} \mathrm{C}\right)$.

In the first heating stage (I-II), the oil-water yields of the three samples were low, although the Longkou sample reached a value of 4.7 wt.\% (Table 1; Fig. 2a). However, in the initial stage of heating the main product was water. During this stage, the semi-coke contents (solid residues obtained by heating the oil shales in Al crucibles) showed a small reduction (Fig. 2b). The gas generated by heating and weight loss also increased slightly.

In the second heating stage (III-VI), the oil-water yields increased significantly. The yields increased by $>30 \mathrm{wt}$.\% for the Longkou oil shale (Fig. 2a). A total of $80 \%-96 \%$

of the oil-water was produced during this heating stage. The expelled product was 
mainly condensate oil with relatively little water. The semi-coke content in this stage also showed a significant decline, with the decrease in the Longkou oil shale being as high as $38 \mathrm{wt} . \%$ (Fig. 2b). The ratio of the change in semi-coke to oil-water expelled was $1.35-1.18$. The gas generated and weight loss during this heating stage were also significant. The ratio of gas to oil-water was $0.18-0.24$.

In the final heating stage $\left(475-520^{\circ} \mathrm{C}\right)$, the oil-water yields only increased slightly (e.g., 1.21 wt.\% for the Longkou oil shale; Fig. 1a). The decrease in semi-coke content was relatively small (Fig. 2b). The gas generated and weight loss increased slightly, particularly for the Minhe sample (4.29 wt.\%; Fig. 2a).

\subsection{Organic geochemistry}

TOC and Rock-Eval pyrolysis analyses were carried on the three original samples, as well as on the samples after each heating step (Table 2).

\subsubsection{TOC contents}

The oil-water yield of the Longkou oil shale was the highest of the three samples (Table 1), and this sample has a TOC content of $62.3 \mathrm{wt} . \%$ (Table 2). The Minhe $(\mathrm{TOC}=41.3 \mathrm{wt} . \%)$ and Junggar $(\mathrm{TOC}=14.45 \mathrm{wt} . \%)$ oil shales have slightly lower TOC contents, although all the samples have high TOC contents.

During heating, all three oil shales showed similar trends. The TOC contents of the samples after stage I were slightly higher than in the original samples (Fig. 3a), possibly due to water removal during heating. However, the TOC increase in the initial heating stage (I-II) was small. During the second heating stage (III-VI) the TOC contents decreased significantly, up to $23.55 \mathrm{wt} . \%$ for the Longkou oil shale (Table 2; Fig. 3a). The TOC contents in the Minhe and Junggar oil shales decreased by 10.50 and $5.77 \mathrm{wt} . \%$, respectively. A total of $25 \%-39 \%$ of the organic matter was converted into oil and gas during this heating stage. In the final heating stage (VII-VIII), the loss of organic matter was smaller and the overall change was not significant (Fig. 3a). Notably, the oil shale sample with the highest TOC content after final heating also had a high content of residual organic carbon (i.e., $>20 \mathrm{wt} . \%$ for the Longkou and Minhe samples). During the full heating process, $41 \%-53 \%$ of the organic matter was converted into oil and gas.

A plot of TOC versus oil-water yield shows a negative correlation in each heating stage. The correlation coefficient of the data on this plot for the Junggar and Longkou samples is $>0.9$ (Fig. 3b). 


\subsubsection{Rock-Eval pyrolysis analyses}

The $S_{1}$ and $S_{2}$ values of the Longkou oil shale (sample with the highest TOC content) were 293.99 and $3.42 \mathrm{mg} / \mathrm{g}$, respectively. Compared with the Longkou oil shale, the Minhe oil shale has a much lower TOC content (62.3 wt.\% versus 41.30 wt.\%), but the $S_{2}$ values of these two oil shales only differ by $<5 \mathrm{mg} / \mathrm{g}$. Therefore, the HI value of the Minhe oil shale could be as high as $694 \mathrm{mg} \mathrm{HC} / \mathrm{g}$ TOC, whereas that of the Longkou oil shale was $472 \mathrm{mg} \mathrm{HC/g}$ TOC. The Junggar oil shale has the lowest TOC content, and its $\mathrm{S}_{2}$ value is also the lowest (TOC $=14.45$ wt. $\%$; $\mathrm{S} 2=73.46 \mathrm{mg} / \mathrm{g}$ ). However, the HI value of the Junggar oil shale is slightly higher than that of the Longkou oil shale (Table 2). The $T_{\max }$ was highest for the Junggar oil shale, followed by the Longkou and Minhe oil shales (Table 2).

The Rock-Eval pyrolysis analysis parameters $\left(\mathrm{S}_{1}, \mathrm{~S}_{2}, \mathrm{~S}_{3}\right.$, and $\left.\mathrm{T}_{\max }\right)$ of the three oil shale samples show systematic changes during the different heating stages (Table 2).

$\mathrm{S}_{1}$ generally represents the hydrocarbon residues in a sample. In the first heating stage (I-II), the $\mathrm{S}_{1}$ values of the samples are lower than in the original sample. This might reflect the removal of free hydrocarbons trapped in the samples during the initial heating. In the second heating stage (III-VI), $S_{1}$ showed a rapid increase followed by a decrease, reaching a maximum after heating step IV. In the final heating stage (VII-VIII), $S_{1}$ returned to a low value (Fig. 4; Table 2). Although the changes in $S_{1}$ values in the three samples show the same trend, the $S_{1}$ value of the Minhe oil shale was generally highest (i.e., up to $14.61 \mathrm{mg} / \mathrm{g}$ in step IV; Fig. 4; Table 2).

The changes in the $S_{2}$ values are obviously different from those of the $S_{1}$ values. $S_{2}$ showed a significant decrease with increasing temperature. In the first stage, $S_{2}$ decreased minimally, and in the second stage $S_{2}$ decreased rapidly with reductions of 258.51, 261.94, and $69.64 \mathrm{mg} / \mathrm{g}$ for the Longkou, Minhe, and Junggar samples, respectively. During the second stage, $88 \%-95 \%$ of $S_{2}$ was converted into oil and gas. In the final heating stage, $S_{2}$ reached its lowest values. For the Longkou sample, which had the highest residual TOC content, $S_{2}$ was highest after heating step VIII. By comparing the amount of $S_{2}$ in the heated and original samples, it is evident that $97.1 \%-98.6 \%$ of the potential hydrocarbons were expelled once a temperature of $520^{\circ} \mathrm{C}$ was reached. The changes in $\mathrm{S}_{2}$ and TOC during the heating process are related to each other. The TOC contents and $\mathrm{S}_{2}$ values for each heating step exhibit a strong positive correlation, with a correlation coefficient of $>0.90$ (Fig. 5). HI values remained largely unchanged during the first heating stage. In the second stage, HI values decreased significantly from 688 to $95 \mathrm{mg} \mathrm{HC} / \mathrm{mg}$ TOC for the Minhe sample, and the decrease amounts for the Junggar and Longkou samples were 455 and $345 \mathrm{mg}$ $\mathrm{HC} / \mathrm{g}$ TOC, respectively. After the final heating stage, the HI values were low $(<30$ mg HC/mg TOC) (Table 2).

$\mathrm{S}_{3}$ values were similar in the original and variably heated samples. The minimum $\mathrm{S}_{3}$ 
value was $0.43 \mathrm{mg} / \mathrm{g}$ (step VII of the Junggar sample) and the maximum was 3.46 $\mathrm{mg} / \mathrm{g}$ (step IV of the Minhe sample). The changes in OI values were irregular, with OI $<10 \mathrm{mg} \mathrm{HC} / \mathrm{mg}$ TOC (Table 2).

$\mathrm{T}_{\max }$ values also show an increasing trend during the heating process. In steps $\mathrm{I}-\mathrm{V}$, the increase in $\mathrm{T}_{\max }$ was small, being $5^{\circ} \mathrm{C}, 7^{\circ} \mathrm{C}$, and $9^{\circ} \mathrm{C}$ for the Junggar, Minhe, and Longkou samples, respectively. $\mathrm{T}_{\max }$ showed a significant increase in the later heating stage, with an increase of $>100^{\circ} \mathrm{C}$ (Table 2; Fig. 4b).

The PI value is the ratio of $S_{1}$ to $S_{1}+S_{2}$. The changes in PI values are similar to $T_{\max }$. In the first heating stage, the PI values are all $\sim 0.02$, which increased in the second heating stage to $0.13,0.17$, and 0.26 for the Longkou, Minhe, and Junggar samples, respectively. In the final heating stage, PI values increased greatly, with a maximum value of 0.5 for the Minhe sample, although it was $<0.3$ for the other two samples (Table 2; Fig. 4b).

\subsubsection{Organic macerals}

Oil shale comprises mainly detrital minerals and organic matter [32] . Based on microscopic observations, lamalginite is the dominant maceral in the oil shale samples ( 72 vol.\%; Fig. 6). Sporinite (13 vol.\%), vitrinite (9 vol.\%), and cutinite (6 vol.\%) are present in small amounts. Exsudatinite is not present in the original samples.

The thermal evolution of the organic macerals with heating was examined in polished sections (Fig. 6). Under yellow fluorescence, in the step I heating stage (room temperature to $185^{\circ} \mathrm{C}$ ) the organic macerals are mainly lamalginite, which is concentrated in bands and shows a strong yellow fluorescence. In heating step II $\left(185-300^{\circ} \mathrm{C}\right)$ the lamalginite fluorescence became less prominent, pale red on its edges, and pale yellow in its interiors. The lamalginite colour fully changed to red in heating step III $\left(300-350^{\circ} \mathrm{C}\right)$. During heating step IV $\left(400-440^{\circ} \mathrm{C}\right)$ the lamalginite colour turned deep red and the fluorescence became weak. The boundaries of individual lamalginite grains also became blurred and only scattered fluorescent spots remained. However, scattered grains of exsudatinite with a strong yellow fluorescence were observed in polished sections. In heating step VI $\left(440-475^{\circ} \mathrm{C}\right)$ the lamalginite fluorescence disappeared completely, and scattered exsudatinite grains with strong fluorescence became visible in cracks or at the edges of mineral grains. The field of view darkened further, apart from rare fluorescent exsudatinite, in heating step VII $\left(475-500^{\circ} \mathrm{C}\right)$. During heating step VIII $\left(500-520^{\circ} \mathrm{C}\right)$ the field of view was essentially black and no fluorescent organic components were visible.

\subsubsection{Ro values}


The average Ro value of the original samples was $0.48 \%$, and its standard deviation based on 20 analyses was $\pm 0.08 \%$. With increased heating the Ro values increased. In particular, for the sample heated to $520^{\circ} \mathrm{C}$ the average Ro value increased to $1.31 \%$. The standard deviation of $>20$ Ro values measured in the same sample increased with further heating (Fig. 7). For example, the standard deviation at $185^{\circ} \mathrm{C}$ was $\pm 0.09 \%$, and it increased to $\pm 0.24 \%$ at $520^{\circ} \mathrm{C}$ (Table 3).

There are significant positive correlations between Ro, $\mathrm{T}_{\max }$, and PI. In steps I-VI, the Ro, $\mathrm{T}_{\max }$, and PI values showed a small increase. In steps VII-VIII, these three parameters increased significantly (Figs 7 and 8).

Ro values have a significant positive correlation with the oil-water content and gas loss. In particular, when Ro values were $0.6 \%-0.8 \%$ the oil and gas contents showed a large increase. Notably, when Ro is $>1.2 \%$ the oil content basically remained unchanged, whereas the gas expelled continues to increase (Fig. 9a and b).

TOC, $S_{2}$, and Ro values show negative correlations with each other. When Ro values are $0.6 \%-0.8 \%$ the TOC contents and $S_{2}$ values decrease markedly and the oil contents increase (Fig. 9c and d).

\section{Discussion}

\subsection{Low-temperature products in the different heating stages}

In the first heating stage (I-II) only water was expelled, along with a small amount of gas, which was associated with a consequent minor weight loss. The TOC contents and $S_{1}$ and $S_{2}$ values decreased only a small amount during this stage (Tables 1 and 2). Wang et al. used infrared spectroscopy to identify free water and some structural water released from kerogen as oil shale was heated up to $350^{\circ} \mathrm{C}$ [33]. Ishiwatari et al. considered that volatiles produced by heating $\left(150-410^{\circ} \mathrm{C}\right)$ organic matter in modern marine sediments were largely water and $\mathrm{CO}_{2}$, whereas those generated from kerogen also included methane, hydrogen, and small amounts of $\mathrm{C}_{2}-\mathrm{C}_{4}$ hydrocarbons. This suggests that low-temperature heating mainly releases water[34].

During the second heating stage (III-VI), abundant oil and a small amount of water were expelled. The ratio of the variations in semi-coke to oil-water was $1.35-1.18$, and that of gas to oil-water was only $0.18-0.24$. In this stage the reduction in TOC contents was $41 \%-53 \%$, while the reduction in the pyrolysis parameter $\mathrm{S}_{2}$ was as high as $90 \%$. These observations indicate that oil was mainly generated during this heating stage.

Plots of PI- $\mathrm{T}_{\max }$ and $\mathrm{HI}-\mathrm{T}_{\max }$ for the second heating stage show that the samples were in the oil generation window (Figs 10 and 11). As such, $300^{\circ} \mathrm{C}$ marked the onset of oil 
generation and $300-475^{\circ} \mathrm{C}$ was the main oil generation window for rapid heating at atmospheric pressure. With increasing temperature, the oil-water yield first increased, reaching a maximum value in step V, and then decreased during steps III-VI (Fig. 2). This indicates that the optimum heating interval for oil shale to generate oil is $400-440^{\circ} \mathrm{C}$. During this heating interval, the oil gradually changed from a low-viscosity liquid to a high-viscosity semi-liquid. The temperature had a significant influence on the yield and ratio of light $\left(\mathrm{C}_{7}-\mathrm{C}_{12}\right)$ to heavy oils $\left(\mathrm{C}_{19}-\mathrm{C}_{24}\right.$ and $\left.\mathrm{C}_{25+}\right)$ [37-41] . Furthermore, based on the boiling point (BP) distribution, oil generated from oil shale can be characterized into the distillation fractions produced in petroleum refining processes, as follows: naphtha $\left(\mathrm{BP}<200^{\circ} \mathrm{C}\right)$, kerosene $\left(200^{\circ} \mathrm{C}<\mathrm{BP}<\right.$ $\left.275^{\circ} \mathrm{C}\right)$, gas oil $\left(275^{\circ} \mathrm{C}<\mathrm{BP}<325^{\circ} \mathrm{C}\right)$, heavy gas oil $\left(325^{\circ} \mathrm{C}<\mathrm{BP}<400^{\circ} \mathrm{C}\right)$, vacuum gas oil $\left(400^{\circ} \mathrm{C}<\mathrm{BP}<538^{\circ} \mathrm{C}\right)$, and residue $\left(\mathrm{BP}>538^{\circ} \mathrm{C}\right)[10,42]$. Therefore, with increasing heating temperature the carbon chain length of shale oil gradually increases, and the heavier fractions, densities, and viscosities gradually increase. Pyrolysis studies on oil shales from China (from the Huadian, Longkou, and Minhe/Yaojie basins) and the western USA have all shown that the generated oil is similar to natural oil. However, the unsaturated hydrocarbon contents are higher in the generated oil and it contains more heteroatomic organic compounds such as oxygen, nitrogen, and sulphur $[10,37-38,40]$. The composition of the oil generated from each heating step requires further investigation.

The pyrolysis parameter $S_{1}$ can reflect the hydrocarbon generation products and residual hydrocarbons in source rocks during the thermal evolution of organic matter [45-48] . An oil saturation index $\left(\mathrm{OSI}=\mathrm{S}_{1} \times 100 / \mathrm{TOC}\right)>100$ indicates that oil might spontaneously flow out of a mudstone source rock [49] . In our experiments, the $S_{1}$ value and OSI reached a maximum in steps IV and V (Table 2; Fig. 4), and the maximum OSI (20-40) of each sample might reflect oil and gas saturation under conditions of rapid heating and atmospheric pressure. This also shows that the oil shale entered a stage of significant hydrocarbon expulsion. However, there are obvious differences in the $S_{1}$ values and OSI amongst these samples (Table 2). Experiments have shown that kerogen has a significant effect on the oil absorption capacity of mudstone, with type I kerogen having the strongest influence [50-51] . Based on a discrimination diagram for organic matter type, the Minhe oil shale contains type I kerogen, whereas the Longkou and Junggar oil shales contain type II kerogen (Fig. 11). This accounts for the higher $S_{1}$ value and OSI of the Minhe oil shale compared with the Longkou and Junggar oil shales. During heating, many cracks are generated that increase the permeability in oil shales [6-8] and, as such, further heating expels the free hydrocarbons and $S_{1}$ gradually decreases. There is also a certain amount of gas generation during this stage, and previous studies of gas from oil shale retorting have shown that the volatiles are dominated by methane and hydrogen. The yields of $\mathrm{C}_{1}-\mathrm{C}_{4}$ alkanes, hydrogen, and carbon monoxide and dioxide also increase linearly with heating temperature [37-38, 40-41] .

In the final heating stage (VII-VIII) there is essentially no oil-water generation or 
expulsion, but there is a reduction in TOC content and increase in gas loss (Fig. 2; Table 2). This suggests that no oil, but some non-condensable gas, is produced during this stage. The primary components of the gas do not change significantly in this stage, although more hydrogen sulfide is released [38] . Both the PI-T $\mathrm{T}_{\max }$ and HI-T $\mathrm{T}_{\max }$ plots showed that the samples had entered the dry gas generation phase in this stage (Figs 10 and 11a). The Longkou and Junggar oil shales produced less gas than the Minhe oil shale during this heating stage (Fig. 2a; Table 1). This is due to the presence of type I kerogen in the Minhe oil shale, which more readily produces gas than type II kerogen at high temperatures.

\subsection{Thermal evolution of organic matter}

Organic matter fluorescence, vitrinite reflectance (Ro), Rock-Eval pyrolysis, and hydrocarbon generation data can reveal the thermal evolution of organic matter [52-57]. The heating of oil shale at low temperatures is a process of rapid catalytic thermal transformation of organic matter at atmospheric pressure.

The products of each heating stage can be used to constrain the thermal evolution of the organic matter in the oil shales. In the first heating stage, water and a small amount of gas were produced, indicating that the organic matter had not entered the stage of large-scale hydrocarbon expulsion. Ro values of $0.48 \%-0.64 \%$, plots of HI- $\mathrm{T}_{\max }[31,36,38]$ and PI-T $\mathrm{T}_{\max }$ [35], and fluorescence changes all indicate that the organic matter transitioned from immature to mature during this stage (Figs 6, 10, and 11a). During heating from room temperature to $300^{\circ} \mathrm{C}$ the organic matter was in the immature to low-mature stage.

In the second heating stage a large amount of oil and some gas were generated, indicating that the organic matter had entered the large-scale hydrocarbon expulsion stage. The Ro values varied from $0.67 \%$ to $0.76 \%$. The data for this stage fall in the mature oil window area in both the HI- $\mathrm{T}_{\max }$ and PI-T $\mathrm{T}_{\max }$ plots (Figs 10 and 11a). The lamalginite fluorescence colour changed gradually from light to deep red, indicating that the organic matter was undergoing thermal degradation during hydrocarbon generation. The amount of oil produced during step VI decreased significantly and the lamalginite fluorescence ceased, which suggests that the thermal evolution gradually transitioned from thermal degradation in the hydrocarbon generation stage to thermal pyrolysis in the wet gas generation stage. All of the above observations reveal that during heating from 300 to $475^{\circ} \mathrm{C}$ the organic matter was mainly in the mature stage.

During the final heating stage there was essentially no oil and only some gas expelled, and Ro values increased to $0.86 \%-1.31 \%$. The samples showed no fluorescence (Fig. 6) and data fall in the dry gas window in the HI- $\mathrm{T}_{\max }$ and PI-T $\mathrm{T}_{\max }$ plots (Figs 10 and 11a). As such, the organic matter was undergoing thermal pyrolysis in the wet-dry gas generation stage, and from 475 to $520^{\circ} \mathrm{C}$ the organic matter was high-mature to 
over-mature.

With rapid heating, Ro values became more scattered as temperature increased (Table 3). The Ro D-values in one sample increased gradually, which might have been related to rapid and non-uniform heating of organic matter. Despite this, the Ro values still reflect the general trends of the thermal evolution of organic matter.

\subsection{Evolution of hydrocarbon generation potential}

In different heating stages (i.e., thermal evolution of organic matter), the hydrocarbon generation potential underwent systematic changes. Using Ro or $T_{\max }$ values as proxies for the thermal evolution of organic matter, it is evident that the organic matter became more mature during heating. With increasing Ro values, $S_{2}$ values decreased significantly (Fig. 9d), indicating that the hydrocarbon generation potential gradually declined with heating.

The organic matter fluorescence characteristics and plot of $\mathrm{HI}-\mathrm{T}_{\max }$ can reveal the changes in hydrocarbon generation potential during heating. In addition, plots of petroleum potential, (PP; $\mathrm{S}_{1}+\mathrm{S}_{2}$ )-TOC [58] and HI-TOC [59], are useful in assessing hydrocarbon generation potential. In the first heating stage (room temperature to $300^{\circ} \mathrm{C}$ ) the oil shale contained abundant type I and II kerogen organic matter with a strong oil generation ability (Fig. 12). This indicates that the initially heated oil shale samples have a high hydrocarbon generation potential.

During the second heating stage $\left(300-475^{\circ} \mathrm{C}\right)$ the plots of PP-T $\max$ and HI-TOC show that with increasing temperature these samples changed from a very good to a fair oil source (Fig. 12). In particular, the hydrocarbon generation potential of the Minhe oil shale containing type I kerogen gradually became similar to that of type II-III kerogen, and type II kerogen showed similar trends (Fig. 11). Notably, the samples still had excellent hydrocarbon generation potential after being heated to $400^{\circ} \mathrm{C}$, which suggests that this temperature was not sufficient to completely expel the generated oil. Tests have shown that when the $S_{2}$ value exceeds $40 \mathrm{mg} / \mathrm{g}$ a sample can be considered an oil shale (oil yield > $3.5 \mathrm{wt} . \%$ ) [60-62], which implies that oil shale and shale oil-gas coexist underground when a mudstone is extremely organic-rich and mature (Fig. 13). In general, as the temperature increases further the hydrocarbon generation potential gradually decreases due to the increase in oil and gas production. However, the heated samples still retain a certain amount of hydrocarbons (Fig. 12) and have a good oil and gas generating capacity.

In the final heating stage $\left(475-520^{\circ} \mathrm{C}\right)$ all the parameters show that the hydrocarbon generating potential of the heated oil shale samples was similar to that of type IV kerogen (Fig. 11). At this point the samples became poor oil or gas source rocks with almost no hydrocarbon generation potential (Fig. 12). However, a large amount of 
residual organic carbon with no hydrocarbon generation potential remained (Table 2).

In summary, at atmospheric pressure, a temperature of $\sim 475^{\circ} \mathrm{C}$ results in almost full oil and gas recovery.

\subsection{Implications for in situ conversion of oil shale}

In situ conversion of oil shale underground is a physical and chemical process involving horizontal drilling and electrical heating technology, which can be considered an "underground refinery" [63] . Our experiments were designed to mimic this process (Fig. 13) and obtain the optimum heating temperature of oil shale during in situ conversion. Furthermore, these experiments simulate the accumulation sequence of unconventional energy sources such as shale oil and gas.

Oil shale is a sedimentary rock with a high organic matter abundance and shallow burial depth $(<1000 \mathrm{~m})$, which is in the low-mature to immature stage (Fig. 13). The oil shale needs to be heated rapidly to promote hydrocarbon generation and expulsion from the kerogen in the shale.

From room temperature to $300^{\circ} \mathrm{C}(\mathrm{Ro}<0.65 \%)$, water is the main product. For an oil shale with high water content, a large amount of water is produced during heating, and this water will continue to absorb heat and keep boiling, which hinders further heating of the oil shale. Therefore, it is suggested that water in oil shale should be fully removed by heating to $300^{\circ} \mathrm{C}$.

Oil and gas begin to be produced in large quantities at $300-400^{\circ} \mathrm{C}$ ( $\mathrm{Ro}=$ $0.65 \%-0.72 \%$ ), but the organic matter has a high hydrocarbon generation potential and retains hydrocarbons, which is when oil shale and shale oil-gas coexist. Therefore, $400^{\circ} \mathrm{C}$ should not be the final temperature for in situ conversion of oil shale.

During heating from 400 to $475^{\circ} \mathrm{C}$ ( $\mathrm{Ro}=0.72 \%-0.76 \%$ ), a large amount of hydrocarbons is generated and expelled, and this stage is the shale oil-gas accumulation zone (Fig. 13). When the oil shale is heated to $440^{\circ} \mathrm{C}$, most of the oil is expelled and the retained hydrocarbon content gradually decreases (Fig. 13), which is thus the optimum temperature for in situ conversion of oil shale when taking into account the heating cost and oil yield.

When the heating temperature exceeds $475^{\circ} \mathrm{C}(\mathrm{Ro}>0.76 \%)$ the organic matter enters the wet or dry gas (i.e., shale gas accumulation zone) generation stage. For oil shale containing type II kerogen, the gas production is very low at this heating stage, but for type I kerogen oil shale (e.g., Minhe oil shale) a significant amount of gas is produced. Accordingly, it is suggested that the final in situ conversion heating temperature of type I kerogen oil shale should be slightly higher than for type II kerogen oil shale. 
The discussion above is based only on laboratory experiments, and the effects of heating time, particle size, system closure, water saturation, pressure and other factors on organic matter thermal evolution and low-temperature products have not been taken into account. It needs further pilot field testing to be revised and optimized. In situ conversion of oil shale is a long-term and complex process and requires further geological and technological investigations to be able to properly exploit this resource.

\section{Conclusions}

Oil shale is an important unconventional energy source that requires in situ conversion. Our heating experiments on oil shales have identified the products of different heating stages, thermal evolution of organic matter, and optimum temperature for rapid hydrocarbon generation during in situ conversion of oil shale.

During the first heating stage (room temperature to $300^{\circ} \mathrm{C}$ ) the main products were water and a small amount of gas, and the organic matter had a high hydrocarbon generation potential and was immature to low-mature.

In the second heating stage $\left(300-475^{\circ} \mathrm{C}\right)$, oil and gas were mainly produced, which represents the oil generation window for oil shale under conditions of atmospheric pressure and rapid heating. In particular, $400-440^{\circ} \mathrm{C}$ was the optimum temperature interval for oil generation, in which the organic matter entered the mature stage. Even after heating to $400^{\circ} \mathrm{C}$ the oil shale expelled a large amount of oil and gas, and the organic matter still had a high hydrocarbon generation potential. Subsequently, the hydrocarbon generation potential gradually decreased. In our experiments the $S_{1}$ peak is considered to represent the maximum oil and gas saturation. The maximum OSI is much larger for type I kerogen oil shale than for type II kerogen oil shale.

In the final heating stage $\left(475-520^{\circ} \mathrm{C}\right)$ a small amount of gas was expelled and the organic matter has almost no hydrocarbon generation potential and is high-mature or over-mature. A large amount of residual organic carbon remained in the final heated samples.

These oil shale experiments provide constraints on the in situ conversion of oil shale to shale oil-gas, and then to shale gas, during the thermal evolution of organic matter. Our results suggest that water should be removed by heating to $300^{\circ} \mathrm{C}$ and that the final temperature for in situ conversion is $440^{\circ} \mathrm{C}$ (but slightly higher for oil shale containing type I kerogen). These constraints need pilot field testing to be optimized.

\section{Acknowledgements}


The research project was financially supported by the National Natural Science Fund (41772092 and 41402088), the Science and Technology Development Plan of Jilin Province (20150520070JH). 


\section{References:}

[1] Dyni, J.R., 2006. Geology and resources of some world oil shale deposits. US Geological Survey Scientific Investigations.

[2] Han, X.X., Kulaots, I., Jiang, X.M., Suuberg, E.M., 2014. Review of oil shale semicoke and its combustion utilization. Fuel. 126(12), 143-161.

[3] Velts, O., Uibu, M., Rudjak, I., Kallas, J., Kuusik, R., 2009. Utilization of oil shale ash to prepare PCC: leachibility dynamics and equilibrium in the ash-water system. Energy Procedia. 1(1), 4843-4850.

[4] Trikkela, A., Kuusik, R., Martins, A., Pihu, T., Stencel, J.M., 2008. Utilization of Estonian oil shale semicoke. Fuel Processing Technology. 89(8), 756-763.

[5] Jiang, X.M., Han, X.X., Cui, Z.G., 2006. New technology for the comprehensive utilization of Chinese oil shale resources. Energy. 32(5), 772-777.

[6] Bai, F.T., Sun, Y.H., Liu, Y.M., Guo, M.Y., 2016. Evaluation of the porous structure of Huadian oil shale during pyrolysis using multiple approaches. Fuel. $187,1-8$.

[7] Burnham, A.K., 2017. Porosity and permeability of Green River oil shale and their changes during retorting. Fuel. 203, 208-213.

[8] Saif, T., Lin, Q.Y., Butcher, A.R., Bijeljic, B., Blunt, M.J., 2017. Multi-scale multi-dimensional microstructure imaging of oil shale pyrolysis using X-ray micro-tomography, automated ultra-high resolution SEM, MAPS Mineralogy and FIB-SEM. Applied Energy. 202, 628-647.

[9] Burnham, A.K., Mcconaghy, J.R., 2014. Semi-Open pyrolysis of oil shale from the Garden Gulch Member of the Green River Formation. Energy \& Fuels. 28(12), 7426-7439.

[10] Na, J.G., Im, C.H., Chung, S.H., Lee, K.B., 2012. Effect of oil shale retorting temperature on shale oil yield and properties. Fuel. 95, 131-135.

[11] Mclendon, T.R., 1984. Evaluation of oil yield losses during the retorting of oil shale at low void fractions. Part 1. the effects of particle size and resource grade. Liq. Fuels Technol (United States). 2:4(2), 439-461.

[12] Lewis, A.E., Braun, R.L., 1981. Retorting and combustion processes in surface oil-shale retorts. Journal of Energy. 5(6), 355-361.

[13] Evans, R.A., Campbell, J.H., 1979. Oil shale retorting - A correlation of selected infrared absorbance bands with process heating rates and oil yield. Situ. 3, 33-51.

[14] Campbell, J.H., Koskinas , G.H., Stout, N.D., Coburn, T.T., 1978. Oil shale retorting - effects of particle size and heating rate on oil evolution and intraparticle oil degradation. Situ. 2(1), 1-47.

[15] Ho, C.H., Clark, B.R., Guerin, M.R., 1976. Direct analysis of organic compounds in aqueous by-products from fossil fuel conversion processes: Oil shale retorting, synthane coal gasification and coed coal liquefaction. Journal of Environmental Science and Health. Part A: Environmental Science and Engineering. 11(7), 481-489.

[16] Lee S., Speight, J.G., Loyalka, S.K., 2014. Handbook of Alternative Fuel Technologies, Second Edision. Crc Press.

[17] Speight, J.G., 1990. Fuel Science and Technology Handbook. New York, NY 
(USA). Marcel Dekker Inc.

[18] Speight, J.G., 2012. Chapter 5-In Situ Retorting. in: Speight JG (Ed.) Shale Oil Production Processes, Gulf Professional Publishing, Boston. 123-138.

[19] Brandt, A.R., 2008. Converting Oil Shale to Liquid Fuels: Energy Inputs and Greenhouse Gas Emissions of the Shell in Situ Conversion Process. Environmental Science \& Technology. 42, 7489-7495.

[20] Fowler, T.D., Vinegar, H.J., 2009. Oil shale ICP-Colorado field pilots. Paper SPE 121164 presented at the SPE Western Regional Meeting, San Jose, California, USA.

[21] Harold, V., 2006. Shell's In Situ Conversion Process. 26th Oil Shale Symposium. Colorado. 16-19.

[22] Crawford, P.M., Biglarbigi, K., Killen, J.R., Dammer, A.R., 2008. Knaus E. "Advances in world oil-shale production technologies". Society of Petroleum Engineers Annual Technical Conference and Exhibition. Denver, Colorado: Society of Petroleum Engineers.

[23] French, G.B., Bartel, W.J., Ridley, R.D., Cha, C.Y., Burton, Iii, R.S., 1997. System for fuel and products of oil shale retort. US, US4014575.

[24] Cha, C.Y., 1977. Method of igniting in situ oil shale retort with fuel rich flue gas. US, US4005752 A.

[25] Burton-Iii, R.S., Cha, C.Y., Ridley, R.D., 1976. Apparatus for obtaining uniform gas flow through an in situ oil shale retort. US, US3941421.

[26] Cook, E.W., 1974. Oil-shale technology in the USA. Fuel. 53, 146-151.

[27] Zhao, J.M., 2017. Method and process for extracting shale oil and gas by fracturing and chemical retorting in oil shale in-situ horizontal well. U.S. Patent. 9, 784, 086, B2.

[28] Sun, Y. H., Bai, F. T., Lü, X. S., Li, Q., Liu, Y. M., Guo, M. Y., Guo, W., Liu, B. C., 2015. A novel energy-efficient pyrolysis process: self-pyrolysis of oil shale triggered by topochemical heat in a horizontal fixed bed. Sci Rep.5(8290): 1-8

[28] Liu, Z.J., Meng, Q.T., Dong, Q. S., Zhu, J. W., Guo, W., Ye, S. Q., Liu, R., Jia, J. L., 2017. Characteristics and resource potential of oil shale in China. Oil Shale. $34,15-41$.

[29] Tao, S., Tang, D. Z., Xu, H., Liang, J. L., Shi, X. F., 2013. Organic geochemistry and elements distribution in dahuangshan oil shale, southern junggar basin: origin of organic matter and depositional environment. International Journal of Coal Geology, 115(8), 41-51.

[30] Lv, D. W, Zong, R. F., Li, Z. X., Wang, D. D., Liu, H. Y., Wu, X. Y., Wang, X. B., Yu, D. M., Feng, T. T., Zhao, L. Y., Yang, Q., Yong, P. L., 2016. Oil shale paleo-productivity disturbed by sea water in a coal and oil shale bearing succession: A case study from the Paleogene Huangxian basin of Eastern China. Journal of Petroleum Science and Engineering. 139, 62-70.

[31] Espitalié, J., Laporte, J.L., Madec, M., Marquis, F., Leplat, P., Paulet, J., Boutefeu, A., 1977. Méthode rapide de caractérisation des roches mères, de leur potentiel pétrolier et de leur degré d'évolution. Revue de l' Institut Francais du Pétrole. 32, 23-42. 
[32] Hutton, A.C., 1987. Petrolographic classification of oil shales. International Journal of Coal Geology 8, 203-231.

[33] Wang, Q., Xu, X.C., Chi, M.S., Zhang, H.X., Cui, D., Bai, J.R., 2015. FT-IR study on composition of oil shale kerogen and its pyrolysis oil generation characteristics. Journal of Fuel Chemistry and Technology. 43(10), 1158-1166 ( in Chinese with English abstract).

[34] Ishiwatari, R., Ishiwatari, M., Rohrback, B.G., Kaplan, I.R., 1977. Thermal alteration experiments on organic matter from recent marine sediments in relation to petroleum genesis. J. Geochimica Et Cosmochimica Acta. 41(6), 815-828.

[35] Waples, D.W., 1985. Geochemistry in Petroleum Exploration. International Human Resources Development Corporation. Boston, p 232.

[36] Espitalié, J., Marquis, F., Barsony, I., 1984. Geochemical logging. In: Voorhess, K.J. (Ed.), Analytical Pyrolysis. Butterworths, Boston, pp. 53-79.

[37] Langford, F.F., Blanc-Valleron, M.M., 1990. Interpreting Rock-Eval pyrolysis data using graphs of pyrolyzable hydrocarbons vs. total organic carbon. AAPG Bulletin. 74, 799-804.

[38] Tyson, R., 1995. Abundance of organic matter in sediments. TOC, hydrodynamic equivalence, dilution and flux effects. Sediment. Organ. Matter Organ. Facies Palynofacies. 81-118.

[37] Wang, W., Ma, Y., Li, S.Y., Yue, C.T., Wu, J.X., Teng, J.S., 2016. Pyrolysis characteristics of Longkou oil shale under optimized condition. J. Journal of Thermal Analysis and Calorimetry. 125(2), 983-990.

[38] Lan, X.Z., Luo, W.J., Song, Y.H., Zhou, J., Zhang, Q.L., 2015. Effect of the Temperature on the Characteristics of Retorting Products Obtained by Yaojie Oil Shale Pyrolysis. Energy \& Fuels. 29,7800-7806.

[39] Wang, S., Jiang, X., Han, X., Tong, J.H., 2013. Effect of residence time on products yield and characteristics of shale oil and gases produced by low-temperature retorting of Dachengzi oil shale. Oil Shale. 30(4), 501-516.

[40] Wang, S., Jiang, X., Han, X., Tong, J.H., 2014. Effect of retorting temperature on product yield and characteristics of non-condensable gases and shale oil obtained by retorting Huadian oil shales. Fuel Processing Technology. 121(1), 9-15.

[41] Dung, N.V., 1990. Yields and chemical characteristics of products from fluidized bed steam retorting of Condor and Stuart oil shales: effect of pyrolysis temperature. Fuel. 69(3), 368-376.

[42] Niu, M.T., Wang, S. , Han, X.X., Jiang, X.M., 2013. Yield and characteristics of shale oil from the retorting of oil shale and fine oil-shale ash mixtures. Applied Energy. 111(11), 234-239.

[45] Ramachandran, K., Babu, V., Behera, B.K., Harinarayana, T., 2013. Source rock analysis, thermal maturation and hydrocarbon generation using rock-eval pyrolysis in parts of Krishna-Godavari basin, India: a case study. Journal of Petroleum Exploration and Production Technology. 3(1), 11-20.

[46] Lu, S.F., Huang, W.B., Chen, F.W., Li, J.J., Wang, M., Xue, H.T., Wang, M.M., Cai, X.Y., 2012. Classification and evaluation criteria of shale oil and gas 
resources: Discussion and application. Petroleum Exploration and Development. 39(2), 268-276.

[47] Hunt, J., 1996. Petroleum Geochemistry and Geology (A Series of books in geology). M. Petroleum geochemistry and geology, p 743.

[48] Delvaux, D., Martin, H., Leplat, P., Paulet, J., 1990. Comparative rock-eval pyrolysis as an improved tool for sedimentary organic-matter analysis. Organic Geochemistry. 16(4), 1221-1229.

[49] Jarvie, D.M., 2012. Shale resource systems for oil and gas: part1-shalegas resource systems. M. //BREYER J A.Shale reservoirs-Giant resources for the 21st Century. AAPG Memoir97.Tulsa. American Association of Petroleum Geologists. 69-87.

[50] Kelemen, S. R., Walters, C.C., Ertas, D., Kwiatek, L.M., \& Curry, D.J., 2006. Petroleum Expulsion Part 2. Organic Matter Type and Maturity Effects on Kerogen Swelling by Solvents and Thermodynamic Parameters for Kerogen from Regular Solution Theory. Energy \& Fuels. 20(1), 301-308.

[51] Ritter, U., 2003. Fractionation of petroleum during expulsion from kerogen. Journal of Geochemical Exploration. 78(8), 417-420.

[52] Cheshire, S., Craddock, P.R., Xu, G.P., 2017. Assessing thermal maturity beyond the reaches of vitrinite reflectance and Rock-Eval pyrolysis: A case study from the Silurian Qusaiba Formation. International Journal of Coal Geology. 180.

[53] Kalkreuth, W., Sherwood, N., Cioccari, G., Silva, Z. C. D., Silva, M., Zhong, N., Zufa, L., 2004. The application of famm ${ }^{\mathrm{TM}}$ (fluorescence alteration of multiples macerals) analyses for evaluating rank of parana basin coals, brazil. International Journal of Coal Geology. 57(3), 167-185.

[54] Stasiuk. L.D., Lockhart, G.D., Nassichuk, W.W., Carlson, J.A., 1999. Thermal maturity evaluation of dispersed organic matter inclusions from kimberlite pipes, Lac de Gras, Northwest Territories, Canada. International Journal of Coal Geology. 40(1), 1-25.

[55] Pradier, B., Bertrand, P., Martinez, L., Laggoun-Defarge, F., 1991. Fluorescence of organic matter and thermal maturity assessment. Organic Geochemistry. 17(4), 511-524.

[56] Tissot, B.P., Welte, D.H., 1984. Petroleum Formation and Occurrence. M. // Petroleum formation and occurrence.

[57] Staplin, F.L., 1977. Interpretation of thermal history from color of particulate organic matter - A review. Palynology. 1(1), 9-18

[58] Peters, K.E., 1986. Guidelines for evaluating petroleum source rock using programmed pyrolysis. AAPG Bull. 70, 318-329.

[59] Jackson, K.S., Hawkins, P.J., Bennett, A.R.J., 1980. Regional facies and geochemical evaluation of the southern Denison Trough, Queensland. APPEA J. 20, 143-158.

[60] Bai, Y.Y., Liu, Z.J., Sun, P.C., Liu, R., Hu, X.F., Zhou, R.J., Xu, Y.B., Zhao, H.Q., Wang, J.P., 2017. Diverse sedimentary conditions during deposition of coal and oil shale from the Meihe basin (Eocene, NE China). Journal of Sedimentary Research. 87(10), 1100-1120. 
[61] Sun, P.C., Sachsenhofer, R.F., Liu, Z.J., Strobl, S.A.I., Meng, Q.T., Liu, R., Zhen, Z., 2013a. Organic matter accumulation in the oil shale- and coal-bearing Huadian Basin (Eocene; NE China). International Journal of Coal Geology. 106, $1-15$.

[62] Sun, P.C., Liu, Z.J., Gratzer, R., Xu, Y.B., Liu, R., Li, B.Y., Meng, Q.T., Xu, J.J., 2013b. Oil yield and bulk geochemical parameters in the Songliao and Huadian Basins (China). a grade classification approach. Oil shale. 30(3), 402-418.

[63] Zhao, W.Z., Hu, S.Y., Hou, L.H., 2018. Connotation and strategic role of in-situ conversion processing of shale oil underground in the onshore China. Petroleum Exploration and Development. 45(4), 563-572. 


\section{Figure captions}

Fig.1. Schematic chart of oil shale heating. (1) Aluminium retort, (2)Heating furnace, (3) Outlet pipe, (4) Thermocouple, (5) Cold junction thermostat, (6) Electric cabinet, (7) Receiver, (8) Colling tank

Fig. 2. Variation in the low-temperature products generated from the three oil shale samples in the different heating steps. a. Oil-water yields and gas and weight loss changes in the different heating steps. b. Variations in the semi-coke contents in the different heating steps.

Fig. 3. Changes in the TOC contents of the three oil shale samples in each heating step. a. The residual TOC contents of the three samples at each heating step. b. A plot of oil-water yields versus TOC contents for the original and heated samples.

Fig. 4. Variations of the sample pyrolysis parameters in each heating step. a. S1 and $\mathrm{S} 2$ values in the different heating steps. $b$. Variations of PI and $\mathrm{T}_{\max }$ values in the different heating steps.

Fig. 5. Relationship between $\mathrm{S} 2$ values and TOC contents in each heating step.

Fig. 6. Fluorescence microscopy images of each heating step. a) A high concentration of lamalginite; b) Pale red on lamalginite edges; c) Red on whole lamalginite; d) The single lamalginite is invisible; e) Exsudatinite with a strong fluorescence, and lamalginite only scattered fluorescent spots remained; f) Only exsudatinite with fluorescence; g) Rare fluorescent exsudatinite remained; h) All organic macerals without fluorescence. All photomicrograohs were taken using a 50× oil immersion objective under UV light.

Fig. 7. Plot of $\mathrm{T}_{\max }$ versus Ro values.

Fig. 8. Plot of PI versus Ro values.

Fig. 9. Plots of Ro values versus oil-water yields, gas loss, TOC contents, and $\mathrm{S}_{2}$ values.

Fig. 10. Plot of PI versus $T_{\max }$ values for each heating step. The diagram is based on reference [35].

Fig. 11. Organic matter discrimination diagram showing data for each heating step. The diagrams are based on references [31, 36-38].

Fig. 12. Plots of the hydrocarbon generation ability of the samples at each heating step. The diagrams are based on references [58-59].

Fig. 13. Model of hydrocarbon generation, oil and gas expulsion, and retained hydrocarbons during the retorting process. A schematic representation of unconventional hydrocarbon accumulation is also shown (modified after reference [56]). 
Table 1. Characteristics of the low-temperature products generated from the oil shale samples after the different heating steps.

\begin{tabular}{|c|c|c|c|c|c|c|c|c|c|}
\hline & Heating stage & I & II & III & IV & V & VI & VII & VIII \\
\hline \multirow{3}{*}{ 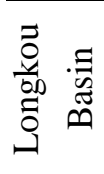 } & Oil and water yield (wt.\%) & 1.14 & 4.70 & 11.65 & 14.64 & 34.82 & 35.76 & 36.97 & 36.97 \\
\hline & Semi-coke yield (wt.\%) & 98.71 & 95.15 & 86.34 & 81.97 & 59.48 & 57.11 & 55.33 & 53.45 \\
\hline & Gas and loss (wt.\%) & 0.15 & 0.15 & 2.01 & 3.39 & 5.70 & 7.13 & 7.70 & 9.58 \\
\hline \multirow{3}{*}{ 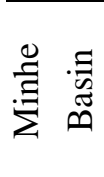 } & Oil and water yield (wt.\%) & 0.18 & 1.02 & 3.71 & 17.09 & 23.25 & 25.67 & 25.67 & 25.67 \\
\hline & Semi-coke yield (wt.\%) & 99.81 & 98.86 & 94.22 & 79.72 & 72.22 & 69.68 & 68.46 & 65.39 \\
\hline & Gas and loss (wt.\%) & 0.01 & 0.12 & 2.07 & 3.19 & 4.53 & 4.65 & 5.87 & 8.94 \\
\hline \multirow{3}{*}{ 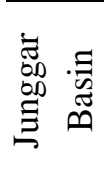 } & Oil and water yield (wt.\%) & 0.30 & 1.16 & 2.13 & 4.91 & 7.87 & 8.40 & 9.05 & 9.14 \\
\hline & Semi-coke yield (wt.\%) & 99.70 & 98.80 & 97.80 & 94.20 & 90.80 & 89.80 & 89.05 & 88.83 \\
\hline & Gas and loss (wt.\%) & 0 & 0.04 & 0.07 & 0.89 & 1.33 & 1.80 & 1.90 & 2.03 \\
\hline
\end{tabular}


Table 2. TOC contents and Rock-Eval pyrolysis parameters of the oil shale samples after the different heating steps.

\begin{tabular}{|c|c|c|c|c|c|c|c|c|c|c|}
\hline \multirow{2}{*}{\multicolumn{2}{|c|}{$\begin{array}{l}\text { Longkou } \\
\text { Samples }\end{array}$}} & TOC & S1 & $\mathrm{S} 2$ & S3 & $\mathrm{S} 1+\mathrm{S} 2$ & Tmax & \multirow[b]{2}{*}{ PI } & $\mathrm{HI}$ & $\mathrm{OI}$ \\
\hline & & \multicolumn{2}{|l|}{ (wt.\%) } & \multicolumn{2}{|c|}{ (mg/g) } & & $\left({ }^{\circ} \mathrm{C}\right)$ & & \multicolumn{2}{|c|}{$\begin{array}{c}(\mathrm{mg} \mathrm{HC} / \mathrm{g} \\
\mathrm{TOC})\end{array}$} \\
\hline \multicolumn{2}{|c|}{ Orginal sample } & 62.30 & 3.42 & 293.99 & 1.39 & 297.41 & 437 & 0.01 & 472 & 2.2 \\
\hline \multirow{8}{*}{ 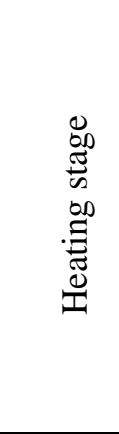 } & I & 62.45 & 5.20 & 289.73 & 2.21 & 294.93 & 439 & 0.02 & 464 & 3.5 \\
\hline & II & 56.85 & 5.52 & 255.02 & 1.72 & 260.54 & 439 & 0.02 & 449 & 3.0 \\
\hline & III & 53.25 & 6.00 & 233.40 & 1.66 & 239.40 & 440 & 0.03 & 438 & 3.1 \\
\hline & IV & 41.75 & 7.75 & 171.01 & 1.74 & 178.76 & 442 & 0.04 & 410 & 4.2 \\
\hline & $\mathrm{V}$ & 35.25 & 5.52 & 129.61 & 1.56 & 135.13 & 448 & 0.04 & 368 & 4.4 \\
\hline & VI & 33.30 & 4.54 & 31.22 & 2.21 & 35.76 & 532 & 0.13 & 94 & 6.6 \\
\hline & VII & 32.95 & 4.45 & 15.24 & 1.86 & 19.69 & 570 & 0.23 & 46 & 5.6 \\
\hline & VIII & 29.35 & 2.27 & 8.54 & 1.14 & 10.81 & 598 & 0.21 & 29 & 3.9 \\
\hline \multirow{2}{*}{\multicolumn{2}{|c|}{ Minhe Samples }} & TOC & $\mathrm{S} 1$ & $\mathrm{~S} 2$ & $\mathrm{~S} 3$ & $\mathrm{~S} 1+\mathrm{S} 2$ & Tmax & \multirow[b]{2}{*}{ PI } & $\mathrm{HI}$ & OI \\
\hline & & \multicolumn{2}{|l|}{ (wt.\%) } & \multicolumn{2}{|c|}{$(\mathrm{mg} / \mathrm{g})$} & & $\left({ }^{\circ} \mathrm{C}\right)$ & & \multicolumn{2}{|c|}{$\begin{array}{c}\text { (mg HC/g } \\
\text { TOC) }\end{array}$} \\
\hline Orgin & mple & 41.30 & 5.43 & 289.26 & 2.11 & 294.69 & 433 & 0.02 & 694 & 5.1 \\
\hline \multirow{8}{*}{ 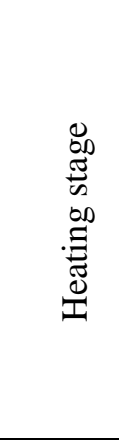 } & I & 41.60 & 4.72 & 288.26 & 1.78 & 292.98 & 435 & 0.02 & 693 & 4.3 \\
\hline & II & 38.20 & 4.95 & 261.55 & 1.49 & 266.5 & 436 & 0.02 & 688 & 3.9 \\
\hline & III & 36.80 & 10.8 & 230.93 & 1.32 & 241.73 & 436 & 0.04 & 628 & 3.6 \\
\hline & IV & 36.65 & 14.61 & 209.98 & 3.46 & 224.59 & 437 & 0.07 & 574 & 9.4 \\
\hline & $\mathrm{V}$ & 34.55 & 13.94 & 191.12 & 1.69 & 205.06 & 440 & 0.07 & 549 & 4.9 \\
\hline & VI & 27.70 & 5.47 & 26.32 & 2.02 & 31.79 & 443 & 0.17 & 95 & 7.3 \\
\hline & VII & 25.35 & 6.99 & 8.08 & 0.45 & 15.07 & 563 & 0.46 & 32 & 1.8 \\
\hline & VIII & 24.25 & 3.98 & 4.06 & 1.36 & 8.04 & 594 & 0.50 & 16 & 5.6 \\
\hline \multirow{2}{*}{\multicolumn{2}{|c|}{ Junggar Samples }} & TOC & $\mathrm{S} 1$ & $\mathrm{~S} 2$ & $\mathrm{~S} 3$ & $\mathrm{~S} 1+\mathrm{S} 2$ & Tmax & \multirow[b]{2}{*}{ PI } & $\mathrm{HI}$ & OI \\
\hline & & (wt.\%) & & \multicolumn{2}{|c|}{$(\mathrm{mg} / \mathrm{g})$} & & $\left({ }^{\circ} \mathrm{C}\right)$ & & \multicolumn{2}{|c|}{$\begin{array}{c}\text { (mg HC/g } \\
\text { TOC) }\end{array}$} \\
\hline Orgin & mple & 14.45 & 0.92 & 73.46 & 1.03 & 74.38 & 441 & 0.01 & 508 & 7.1 \\
\hline \multirow{8}{*}{ 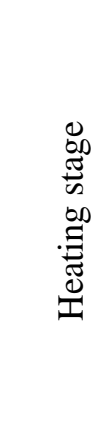 } & I & 14.55 & 1.35 & 72.89 & 1.46 & 74.24 & 441 & 0.02 & 501 & 10.0 \\
\hline & II & 13.55 & 1.6 & 67.36 & 1.17 & 68.96 & 442 & 0.02 & 497 & 8.6 \\
\hline & III & 10.90 & 1.67 & 53.43 & 0.74 & 55.10 & 442 & 0.03 & 490 & 6.8 \\
\hline & IV & 9.70 & 2.23 & 35.94 & 0.52 & 38.17 & 443 & 0.06 & 371 & 5.4 \\
\hline & $\mathrm{V}$ & 8.01 & 1.96 & 20.29 & 0.68 & 22.25 & 446 & 0.09 & 253 & 8.5 \\
\hline & VI & 7.79 & 1.13 & 3.25 & 0.75 & 4.38 & 564 & 0.26 & 42 & 9.6 \\
\hline & VII & 7.69 & 0.76 & 2.20 & 0.62 & 2.96 & 584 & 0.26 & 29 & 8.1 \\
\hline & VIII & 6.94 & 0.38 & 1.05 & 0.43 & 1.43 & 600 & 0.27 & 15 & 6.2 \\
\hline
\end{tabular}


Table 3. Ro values of the oil shale samples after the different heating steps.

\begin{tabular}{ccccc}
\hline Heating stage & $\begin{array}{c}\text { Heating temperature } \\
\left({ }^{\circ} \mathrm{C}\right)\end{array}$ & $\begin{array}{c}\text { Statistical } \\
\text { number }\end{array}$ & $\begin{array}{c}\text { Ro } \\
(\%)\end{array}$ & $\begin{array}{c}\text { Error } \\
(\%)\end{array}$ \\
\hline Orginal sample & Room temperature & 20 & 0.48 & \pm 0.08 \\
I & Room temperature -185 & 22 & 0.61 & \pm 0.09 \\
II & $185-300$ & 20 & 0.64 & \pm 0.10 \\
III & $300-350$ & 20 & 0.67 & \pm 0.12 \\
IV & $350-400$ & 20 & 0.72 & \pm 0.14 \\
V & $400-440$ & 20 & 0.74 & \pm 0.16 \\
VI & $440-475$ & 20 & 0.76 & \pm 0.20 \\
VII & $475-500$ & 20 & 0.86 & \pm 0.22 \\
VIII & $500-520$ & 21 & 1.31 & \pm 0.24 \\
\hline
\end{tabular}




\section{Experimental constraints on the evolution of organic matter in oil shales during heating: implications for enhanced in situ oil recovery from oil shales}

\footnotetext{
Fengning $\mathrm{Yu}^{1,2}$, Pingchang Sun ${ }^{1,2^{*}}$, Kang'an Zhao ${ }^{1,2}$, Lin $^{\prime}{ }^{3}$, Xuemei Tian ${ }^{4}$

1. College of Earth Sciences, Jilin University, Changchun, Jilin 130061, China

2. Key-Lab for Oil Shale and Paragenetic Minerals of Jilin Province, Changchun, Jilin 130061, China

3. School of Earth and Environmental Sciences, The University of Manchester, Manchester, M13 9PL, UK

4. College of Education Science, JilinNormalUniversity, Siping, Jilin 136000, China
}

*Corresponding author: College of Earth Sciences, Jilin University, Jianshe str. 2199, Changchun 130061, China.

Tel.: 008613674313295

Fax.: 008643188502603

E-mail addresses: sunpingchang711@ @ 126.com 


\begin{abstract}
In situ oil shale conversion experiments have revealed that to efficiently obtain shale oil, factors such as heating temperature, products, and matter thermal evolution of organic matter during heating need to be optimized. In this study, oil shales from China were subjected to retorting experiments involving eight heating steps. During steps I-II $\left(\leq 300^{\circ} \mathrm{C}\right)$, the expelled product is mainly water, the hydrocarbon generation potential (PP) of the samples was extremely high, and the organic matter was in the immature to low-mature stage. The oil shale produced a large amount of oil in steps III-VI $\left(300-475^{\circ} \mathrm{C}\right)$, and the TOC contents and S2 of the shale showed the greatest decreases during these steps. The analysis data suggest that the organic matter entered the mature stage during these steps. After heating to $400^{\circ} \mathrm{C}$ and expelling a large amount of oil and gas, the PP decreased gradually. From 475 to $520^{\circ} \mathrm{C}$ (steps VII-VIII), only a small amount of gas was produced and the organic matter had almost no PP in the high- and over-mature stages. Based on our experimental results, in situ conversion of oil shale the final heating temperature should be $\sim 440^{\circ} \mathrm{C}$. These constraints require further field testing to be properly optimized.
\end{abstract}

Keywords: oil shale; heating experiments; released products; organic matter; thermal evolution; in situ conversion 


\section{Introduction}

Oil shale is an important unconventional energy source with estimated global in situ resource of $411 \times 10^{9} \mathrm{t}$. As such, oil shale research and exploration have become important in many countries [1]. At present, the main use of oil shale is in surface retorting and electricity generation, although numerous advances have been made in the further utilization of oil shales [2-5].

Numerous studies have investigated the effects of heating temperature and rate, and particle size, on oil yield, gas evolution, shale oil composition, and oil shale pyrolysis, porosity, and permeability during retorting [6-15].These studies have all shown that heating plays an important role in oil shale retorting. In addition, the increase in shale porosity and permeability caused by hydrocarbon expulsion from organic matter and the oil-gas composition also show regular changes during heating. Chemical kinetics, minerals composition influence and oil shale process design has been carried out many years [16-19]. These results have been important in guiding the efficient use of oil shale. There are some environmental problems related to oil shale surface retorting, such as water-air pollution and waste residue stacking, which restrict the large-scale use of oil shale resources. Therefore, numerous pilot in situ conversion experiments on oil shale have been carried out [20-23], such as the Shell Company In Situ

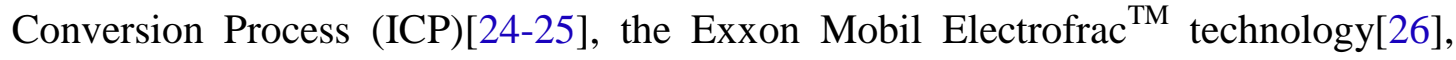
and the Occidental modified in situ (MIS) technology [27-30]. In China, the technologies for on-site in situ conversion experiments on oil shale Songliao Basinhave been developed by the Zhongcheng Group and Jilin University, which have led to favourable outcomes [31-32]. The heating temperature of the Zhongcheng oil shale insitu conversion was ca.520-550 ${ }^{\circ} \mathrm{C}$ and, after 10dof heating, a large amount of shale oil was obtained. The heating temperature of oil shale using the in situ conversion technology of Jilin University was $>400^{\circ} \mathrm{C}$, and gas and oil production occurred after 15 and $17 \mathrm{~d}$, respectively. The oil shale in the Songliao Basin is characterized by a high oil content, large thickness, uniform distribution, low dip angle, and dense mudstone above and below the oil shale [33-34].

In situ conversion experiments on oil shale have focused on the heating technology, fracturing and sealing of the oil shale layer, and reservoir properties. However, during in situ heating the thermal evolution of organic matter and hydrocarbon generation and expulsion characteristics are also important in the efficient development and utilization of oil shale. To investigate this further, we conducted heating experiments on oil shales. Our experiments identified the heating required to reach the oil generation window and constrain the evolution of organic matter and hydrocarbon generation potential of oil shale when it is heated rapidly at atmospheric pressure. These results might guide the heating strategies of future pilot experiments designed to optimize the recovery and utilization of products produced by in situ conversion of oil shale. It may also reveal the pattern of hydrocarbon generation from organic matter in an open system. 


\section{Samples and methods}

Three fine-grained oil shale samples formed the basis of this study. These samples are from the Minhe (Gansu Province, northwestern China) [35], Junggar (Xinjiang Uygur Autonomous Region, northwesternChina) [36], and Huangxian (Shandong Province, east China)[37], and Meihe basins [38] (Fig. 1), and the first three basins' oil shale are currently under development. The detailed information about these four samples was shown in table 1.Oil shale in China is mainly deposited in continental basins, and could be divided into three genetic types, namely aphytal sapropelic oil shale (Junggar Basin oil shale), semi-deep lake humic-sapropelic oil shale (Minhe Basin oil shale) and limnetic sapropelic oil shale(Huangxian and Meihe basins oil shale)[39]. Therefore, these four samples could represent all types of oil shale in China. One high-quality (i.e., high oil yield) sample of oil shale from each basin was selected for experimental heating and analysis. Except Ro and organic macerals observation, other tests were parallel sample comparison.

The low-temperature step-heating experiments, total organic carbon (TOC) analyses, Rock-Eval pyrolysis analyses, organic maceral microscopic observations, and vitrinite reflectance determinations (Ro) were undertaken in the Key Laboratory for Oil Shale and Paragenetic Minerals of Jilin Province, Changchun, China. About 50g oil shale $\left(\mathrm{W}_{\text {shale }}\right)$ samples (particles size less than $1 \mathrm{~cm}$ ) were heated following the Chinese Petroleum Chemical Industry Standard SH/T0508-92in a low-temperature furnace in eight steps in dry open system (Fig. 2): room temperature to $185^{\circ} \mathrm{C}$ (I), $185-300^{\circ} \mathrm{C}$ (II), $300-350^{\circ} \mathrm{C}$ (III), $350-400^{\circ} \mathrm{C}(\mathrm{IV}), 400-440^{\circ} \mathrm{C}(\mathrm{V}), 440-475^{\circ} \mathrm{C}(\mathrm{VI})$, $475-500^{\circ} \mathrm{C}$ (VII), $500-520^{\circ} \mathrm{C}$ (VIII). This heating method was established by Fushun Mining Company based on thousands of experiments atdifferent heating rates and temperatures. Fully automated heating equipment and a thermocouple feedback system were used to ensure the accuracy of each heating temperature (Fig. 2), with errors of $\pm 5^{\circ} \mathrm{C}$. For each heating step, the samples were heated at a rate of $10^{\circ} \mathrm{C} / \mathrm{min}$, and then held at each temperature step for $30 \mathrm{~min}$ (almost no product was discharged after $30 \mathrm{~min}$ ). The product in the receiver (Fig.2) is a mixture of oil and water $\left(\mathrm{W}_{\text {oil+water }}\right)$, and $80 \mathrm{~mL}$ of xylene was added to this mixture. The oil-water products and xylene were boiled and the volume of water determined $\left(\mathrm{V}_{\text {water }}\right)$. $\mathrm{W}_{\text {oiltwater }}$ and $\mathrm{V}_{\text {water }}$ were used to calculate the oil yield [ $\left.\left(\mathrm{W}_{\text {oil+water }}-\mathrm{V}_{\text {water }} \times 1 \mathrm{~g} / \mathrm{cm}^{3}\right) / \mathrm{W}_{\text {shale }} \times 100\right]$ and water yield $\left(\mathrm{V}_{\text {water }} \times 1 \mathrm{~g} / \mathrm{cm}^{3} / \mathrm{W}_{\text {shale }} \times 100\right)$. The semi-coke yield is the ratio of solid residue to sample weight. Finally, it is possible to calculate the gas loss ratio (100 oil yield - water yield - semi-coke yield).

TOC contents were determined using a LECO CS-230 instrument and Rock-Eval pyrolysis was carried out with a Rock-Eval 6 instrument following standard procedures [40-41]. The TOC contents and pyrolysis parameters were used to calculate the HI $\left(\mathrm{S}_{2} / \mathrm{TOC} \times 100\right)$ and $\mathrm{OI}\left(\mathrm{S}_{3} / \mathrm{TOC} \times 100\right)$ values. Organic macerals were observed in polished blocks of whole-rock samples cut perpendicular to bedding planes using a Zeiss Axio Scope A1 microscope under reflected white and UV light (fluorescence). A number of desmocollinite macerals (>100) were subjected to Ro 
measurements using the same instrument equipped with a microphotometer and under reflected white light.

\section{Results}

\subsection{Effects of low-temperature heating}

The three samples of oil shale underwent three distinct stages during heating: (1) steps I-II (room temperature to $\left.300^{\circ} \mathrm{C}\right)$; 2. steps III-VI $\left(300-475^{\circ} \mathrm{C}\right)$; 3. steps VII-VIII $\left(475-520^{\circ} \mathrm{C}\right)$.

In the first heating stage (I-II), the oil yields of the four samples were low, especially oil yield was basically zero in the I heating stage (Table 2; Fig. 3a). However, in the initial stage of heating the main product was water. During this stage, the semi-coke contents (solid residues obtained by heating the oil shales in Al retort) showed a small reduction (Fig. 3b). The gas generated by heating and weight loss also increased slightly.

In the second heating stage (III-VI), the expelled product was mainly condensate oil, and the oil yields increased significantly. The yields increased by $>26 \mathrm{wt} . \%$ for the Huangxian oil shale (Fig. 3a). A total of $88 \%-98 \%$ of the oil was produced during this heating stage. In this stage, water was produced by the pyrolysis of organic matter, and the ratio of oil content to water content was lower (0.54-4.63) in heating stages III-IV and higher (1.29-11.20) in heating stagesV-VI. The semi-coke content in this stage also showed a significant decline, with the decrease in the Huangxian oil shale being as high as $38 \mathrm{wt} . \%$ (Fig. 3b). The ratio of the change in semi-coke to oil-water expelled was 1.18-1.36(oil to semi-coke was $0.44-0.71$ ). The gas generated and weight loss during this heating stage were also significant. The ratio of gas to oil-water was $0.18-0.36$ (gas to oil was $0.24-0.61$ ).

In the final heating stage $\left(475-520^{\circ} \mathrm{C}\right)$, the oil and water yields only increased slightly (e.g., 1.17wt. \% and 0.04 wt. \% for the Huangxian oil shale, respectively; Fig. 3a). The decrease in semi-coke content was relatively small (Fig. 3b). The gas generated and weight loss increased slightly, particularly for the Minhe sample (4.30 wt. \%; Fig. 3a).

\subsection{Organic geochemistry}

TOC and Rock-Eval pyrolysis analyses were carried on the three original samples, as well as on the samples after each heating step (Table 3).

\subsubsection{TOC contents}

The oil yield and gas content of the Huangxian oil shale was the highest of the three samples (Table 3), and this sample has a TOC content of 56.35 wt.\% (Table 3). The Minhe $($ TOC $=41.90 \mathrm{wt} . \%)$, Meihe $($ TOC $=25.46 \mathrm{wt} . \%)$, and Junggar $(\mathrm{TOC}=14.53$ 
wt. \%) oil shales have slightly lower TOC contents, although all the samples have high TOC contents.

During heating, all four oil shales showed similar trends. The TOC contents of the samples after stage I were slightly higher than in the original samples (Fig. 4a), possibly due to structural water removal during heating (free water has been removed before TOC test). However, the TOC increase in the initial heating stage (I-II) was small. During the second heating stage (III-VI) the TOC contents decreased significantly, up to 22.34 wt.\% for the Huangxian oil shale (Table 3; Fig. 4a). The TOC contents in the Minhe, Meihe and Junggar oil shales decreased by 12.28, 7.32 and 6.71 wt. $\%$, respectively. A total of $29 \%-46 \%$ of the organic matter was converted into oil and gas during this heating stage. In the final heating stage (VII-VIII), the loss of organic matter was smaller and the overall change was not significant (Fig. 4a). Notably, the oil shale sample with the highest TOC content after final heating also had a high content of residual organic carbon (i.e., $>20 \mathrm{wt} . \%$ for the Huangxian and Minhe samples). During the full heating process, $33 \%-55 \%$ of the organic matter was converted into oil and gas.

A plot of TOC versus oil yield shows a negative correlation in each heating stage. The correlation coefficient of the data on this plot for the all samples is $>0.8$ (Fig. 4b). Oil shale samples with high TOC and oil yield, the slopes were relatively high (i.e., 1.17 for the Huangxian and Minhe samples, and 0.80 and 0.81 for the Meihe and Junggar samples, respectively).

\subsubsection{Rock-Eval pyrolysis analyses}

Due to the high organic matter content and its low maturity, $S_{1}$ was small and $S_{2}$ was high in the original oil shale sample. The $S_{1}$ and $S_{2}$ values of the Huangxian oil shale (sample with the highest TOC content) were 292.84 and $3.30 \mathrm{mg} / \mathrm{g}$, respectively. Compared with the Huangxian oil shale, the Minhe oil shale has a much lower TOC content (56.35 wt. \% versus $41.90 \mathrm{wt} . \%$ ), but the $\mathrm{S}_{2}$ values of these two oil shales only differ by $<3 \mathrm{mg} / \mathrm{g}$. Therefore, the HI value of the Minhe oil shale could be as high as $702 \mathrm{mg} \mathrm{HC} / \mathrm{g}$ TOC, whereas that of the Huangxian oil shale was $516 \mathrm{mg} \mathrm{HC} / \mathrm{g}$ TOC. The Junggar oil shale has the lowest TOC content, and its $S_{2}$ value is also the lowest (TOC $=14.45$ wt. $\% ; \mathrm{S} 2=73.46 \mathrm{mg} / \mathrm{g}$ ), and the HI value of the Junggar oil shale is similar to that of the Huangxian oil shale (Table3). The Meihe oil shale has the third highest TOC content and S2 value (TOC $=25.46$ wt. $\%$; S2 $=99.83 \mathrm{mg} / \mathrm{g}$ ). However, the HI value is lowest in the Meihe oil shale. The $\mathrm{T}_{\max }$ was highest for the Junggar oil shale, followed by the Huangxian, Minhe and Meihe oil shales (Table 3).

The Rock-Eval pyrolysis analysis parameters $\left(S_{1}, S_{2}, S_{3}\right.$, and $\left.T_{\max }\right)$ of the four oil shale samples show systematic changes during the different heating stages (Table 3 ).

$\mathrm{S}_{1}$ generally represents the hydrocarbon residues in a sample. In the first heating stage (I-II), the $\mathrm{S}_{1}$ values of the samples are similar to or slightly higher than in the original 
sample. This may be because most of the free hydrocarbons remain in the oil shale due to the lower pressure in the Al retort during initial heating, and the oil shale produces limited hydrocarbons. In the second heating stage (III-VI), $\mathrm{S}_{1}$ showed a rapid increase followed by a decrease, reaching a maximum after heating step IV. In the final heating stage (VII-VIII), the reduction in hydrocarbon generation meant that the pressure in the $\mathrm{Al}$ retort was low, and small amounts of hydrocarbons remaining in the samples were expelled. $S_{1}$ the returned to a low value and still existed in sample (Fig. 5; Table 3). Although the changes in $S_{1}$ values in the four samples show the same trend, the $S_{1}$ value of the Minhe oil shale was generally highest (i.e., up to 14.68 $\mathrm{mg} / \mathrm{g}$ in step IV; Fig. 5; Table 3).

The changes in the $S_{2}$ values are obviously different from those of the $S_{1}$ values. $S_{2}$ showed a significant decrease with increasing temperature. In the first stage, $\mathrm{S}_{2}$ remained unchanged during I heating stage, and then it decreased minimally(RE6 pyrolys is start to detect $S_{2}$ from $200^{\circ} \mathrm{C}$ ), and in the second stage $S_{2}$ decreased rapidly with reductions of 233.99, 245.57, 91.17, and $69.64 \mathrm{mg} / \mathrm{g}$ for the Huangxian, Minhe, Meihe, and Junggar samples, respectively. During the second stage, $88 \%-95 \%$ of $\mathrm{S}_{2}$ was converted into oil and gas. In the final heating stage, $S_{2}$ reached its lowest values. For the Huangxian sample, which had the highest residual TOC content, $\mathrm{S}_{2}$ was highest after heating step VIII. By comparing the amount of $\mathrm{S}_{2}$ in the heated and original samples, it is evident that $96.9 \%-98.8 \%$ of the potential hydrocarbons were expelled once a temperature of $520^{\circ} \mathrm{C}$ was reached. The changes in $\mathrm{S}_{2}$ and TOC during the heating process are related to each other. The TOC contents and $\mathrm{S}_{2}$ values for each heating step exhibit a strong positive correlation, with a correlation coefficient of $>0.90$ (Fig.6). HI values remained largely unchanged during the first heating stage. In the second stage, HI values decreased significantly from 682 to 96 $\mathrm{mg} \mathrm{HC} / \mathrm{mg}$ TOC for the Minhe sample, and the decrease amounts for the Junggar, Huangxian and Meihe samples were 451, 401, and $356 \mathrm{mg} \mathrm{HC} / \mathrm{g} \mathrm{TOC}$, respectively. After the final heating stage, the HI values were low $(<30 \mathrm{mg} \mathrm{HC} / \mathrm{mg}$ TOC) (Table 3).The slopes shown in Fig. 6 highlight the decreasing hydrocarbon generation potential of different samples with variable organic matter types and abundances during rapid heating. These slopes suggest that the Minhe oil shale with the highest HI has the highest hydrocarbon generation potential, followed by the Huangxian, Meihe, and Junggar oil shales.

$\mathrm{S}_{3}$ values were similar in the original and variably heated samples. The minimum $\mathrm{S}_{3}$ value was $0.47 \mathrm{mg} / \mathrm{g}$ (step VII of the Junggar sample) and the maximum was $6.03 \mathrm{mg} / \mathrm{g}$ (the Meiheoriginal oil shale sample). The changes in OI values were irregular, with OI $<25 \mathrm{mg} \mathrm{HC} / \mathrm{mg}$ TOC (Table 3).

$\mathrm{T}_{\max }$ values also show an increasing trend during the heating process (Fig. 7). In steps $\mathrm{I}-\mathrm{V}$, due to the heating temperature was smaller than the Tmax of original samples, the increase in $\mathrm{T}_{\max }$ was small, being $5^{\circ} \mathrm{C}, 7^{\circ} \mathrm{C}, 11^{\circ} \mathrm{C}$, and $21^{\circ} \mathrm{C}$ for the Junggar, Minhe, Huangxian,andMeihe samples, respectively. $\mathrm{T}_{\max }$ showed a significant increase in the 
later heating stage, with an increase of $>100^{\circ} \mathrm{C}$. The very low peak values of $\mathrm{S}_{2}$ result in a largedifference in $\mathrm{T}_{\max }$ values amongst different samples in the final heating stage (Table 3; Fig. 7).

The PI value is the ratio of $S_{1}$ to $S_{1}+S_{2}$. The changes trendin PI values are similar to $\mathrm{T}_{\max }$. In the first heating stage, the PI values are all $\sim 0.02$, which increased in the second heating stage to $0.11,0.16,0.17$, and 0.24 for the Huangxian, Meihe, Minhe, and Junggar samples, respectively. In the final heating stage, PI values increased greatly, with a maximum value of 0.5 for the Minhe sample, although it was $<0.32$ for the other three samples (Table 3; Fig. 8).

\subsubsection{Organic macerals}

Oil shale comprises mainly detrital minerals and organic matter [42]. In this paper, Minhe samples with high HI were used for organic macerals observation. Based on microscopic observations, lamalginite is the dominant maceral in the Minhe oil shale samples ( 72 vol. \%; Fig. 8). Sporinite (13 vol. \%), vitrinite (9 vol. \%), and cutinite (6 vol. \%) are present in small amounts. Exsudatinite is not present in the original samples.

The thermal evolution of the organic macerals with heating was examined in polished sections (Fig. 8). Under yellow fluorescence, in the step I heating stage (room temperature to $185^{\circ} \mathrm{C}$ ) the organic macerals are mainly lamalginite, which is concentrated in bands and shows a strong yellow fluorescence. In heating step II $\left(185-300^{\circ} \mathrm{C}\right)$ the lamalginite fluorescence became less prominent, pale red on its edges, and pale yellow in its interiors. The lamalginite colour fully changed to red in heating step III $\left(300-350^{\circ} \mathrm{C}\right)$. During heating step IV $\left(400-440^{\circ} \mathrm{C}\right)$ the lamalginite colour turned deep red and the fluorescence became weak. The boundaries of individual lamalginite grains also became blurred and only scattered fluorescent spots remained. However, scattered grains of exsudatinite with a strong yellow fluorescence were observed in polished sections. In heating step VI $\left(440-475^{\circ} \mathrm{C}\right)$ the lamalginite fluorescence disappeared completely, and scattered exsudatinite grains with strong fluorescence became visible in cracks or at the edges of mineral grains. The field of view darkened further, apart from rare fluorescent exsudatinite, in heating step VII $\left(475-500^{\circ} \mathrm{C}\right)$. During heating step VIII $\left(500-520^{\circ} \mathrm{C}\right)$ the field of view was essentially black and no fluorescent organic components were visible.

\subsubsection{Ro values}

Meihe oil shale samples with relatively low HI values were used for Ro testing. Vitrinite is the dominant maceral in the Meihe oil shale samples ( 70 vol. \%; Fig. 8). The grain size of desmocollinite in the Meihe samples is much larger than that in the Minhe samples. Therefore, compared with the other samples, the Meihe samples are the most suitable for Ro testing. The average Ro value of the original samples was $0.396 \%$, and its standard deviation based on 103 analyses was $0.016 \%$. The 
desmocollinite showed grey. With increased heating the Ro values increased, and the colour of desmocollinite changed from grey to bright white (Fig. 8). In particular, for the sample heated to $520^{\circ} \mathrm{C}$ the average Ro value increased to $1.593 \%$. The standard deviation and error of $>100$ Ro values measured in the same sample increased with further heating (Fig. 8). For example, the standard deviation at $185^{\circ} \mathrm{C}$ was $0.020 \%$ (error: -0.033 to $0.043 \%$ ), and it increased to $\pm 0.059 \%$ at $520^{\circ} \mathrm{C}$ (error: -0.148 to $0.179 \%$ ) (Table 4).

There are significant positive correlations between Ro, $T_{\max }$, and PI. In steps I-VI, the Ro, $\mathrm{T}_{\max }$, and PI values showed a small increase. In steps VII-VIII, these three parameters increased significantly (Fig. 8).

Ro values have a significant positive correlation with the oil and gas contents. In particular, when Ro values were $0.7 \%-1.3 \%$ the oil and gas contents showed a large increase. Notably, when Ro is $>1.5 \%$ the oil and gas content basically remained unchanged (Fig. 9).

TOC, $\mathrm{S}_{2}$, and Ro values show negative correlations with each other. When Ro values are $0.7 \%-1.3 \%$ the TOC contents and $S_{2}$ values decrease markedly and the oil and gas contents increase (Fig. 9).

\section{Discussion}

\subsection{Low-temperature products in the different heating stages}

In the first heating stage (I-II) only water was expelled, along with a small amount of gas, which was associated with a consequent minor weight loss. The TOC contents and $S_{1}$ and $S_{2}$ values decreased only a small amount during this stage (Tables 2 and 3). Wang et al. used infrared spectroscopy to identify free water and some structural water released from kerogen as oil shale was heated up to $350^{\circ} \mathrm{C}$ [43]. Ishiwatari et al.considered that volatiles produced by heating $\left(150-410^{\circ} \mathrm{C}\right)$ organic matter in modern marine sediments were largely water and $\mathrm{CO}_{2}$, whereas those generated from kerogen also included methane, hydrogen, and small amounts of $\mathrm{C}_{2}-\mathrm{C}_{4}$ hydrocarbons. This suggests that low-temperature heating mainly releases water [44].

During the second heating stage (III-VI), abundant oil and a small amount of water were expelled. The ratio of the variations in oil to semi-coke was $0.44-0.71$, and that of gas to oil was $0.24-0.61$. In this stage the reduction in TOC contents was $29 \%-46 \%$, while the reduction in the pyrolysis parameter $\mathrm{S}_{2}$ was as high as $90 \%$. These observations indicate that oil was mainly generated during this heating stage. Gas was also produced, particularly from the low -HI and high-TOC oil shales.

Plots of PI- $\mathrm{T}_{\max }$ and HI- $\mathrm{T}_{\max }$ for the second heating stage show that the samples were in the oil generation window (Figs 10 and 11 ). As such, $300^{\circ} \mathrm{C}-350^{\circ} \mathrm{C}$ marked the onset of oilgeneration and $350^{\circ} \mathrm{C}-475^{\circ} \mathrm{C}$ was the main oil generation window for 
rapid heating at atmospheric pressure. With increasing temperature, the oil yield first increased, reaching a maximum value in step $\mathrm{V}$, and then decreased during steps III-VI (Fig. 3). This indicates that the optimum heating interval for oil shale to generate oil is $400-440^{\circ} \mathrm{C}$. The temperature had a significant influence on the yield and ratio of light $\left(\mathrm{C}_{7}-\mathrm{C}_{12}\right)$ to heavy oils $\left(\mathrm{C}_{19}-\mathrm{C}_{24}\right.$ and $\left.\mathrm{C}_{25+}\right)$ [49-53]. Furthermore, in this experiment the low-temperature retorting furnace (Fig. 2) also results in distillation. Based on the boiling point (BP) distribution, oil generated from oil shale can be characterized into the distillation fractions produced in petroleum refining processes, as follows: naphtha $\left(\mathrm{BP}<200^{\circ} \mathrm{C}\right)$, kerosene $\left(200^{\circ} \mathrm{C}<\mathrm{BP}<275^{\circ} \mathrm{C}\right)$, gas oil $\left(275^{\circ} \mathrm{C}<\mathrm{BP}<325^{\circ} \mathrm{C}\right)$, heavy gas oil $\left(325^{\circ} \mathrm{C}<\mathrm{BP}<400^{\circ} \mathrm{C}\right)$, vacuum gas oil $\left(400^{\circ} \mathrm{C}\right.$ $\left.<\mathrm{BP}<538^{\circ} \mathrm{C}\right)$, and residue $\left(\mathrm{BP}>538^{\circ} \mathrm{C}\right)[10,54]$. With increasing temperature, the oil viscosity in the receiver increases, and the oil even becomes solid in the later heating stages. Therefore, with increasing heating temperature, the carbon chain length of the shale oil gradually increases, and the heavier fractions are gasified and discharged from the Al retort to the receiver. During this heating interval, the oil changed gradually from a low-viscosity to high-viscosity semi-liquid. Pyrolysis studies on oil shales from China (from the Huadian, Huangxian, and Minhe/Yaojie basins) and the western USA (Green River Basin) have all shown that the generated oil is similar to natural oils. However, the unsaturated hydrocarbon contents are higher in the generated oil and it contains more heteroatomic organic compounds such as oxygen, nitrogen, and sulphur [10, 47-48, 52]. The composition of the oil generated from each heating step requires further investigation.

The pyrolysis parameter $S_{1}$ can reflect the hydrocarbon generation products and residual hydrocarbons in source rocks during the thermal evolution of organic matter [55-58]. An oil saturation index $\left(\mathrm{OSI}=\mathrm{S}_{1} \times 100 / \mathrm{TOC}\right)>100$ indicates that oil might spontaneously flow out of a mudstone source rock [59]. In our experiments, the $S_{1}$ value and OSI reached a maximum in steps IV and V (Table 3; Fig. 5), and the maximum OSI (15-40) of each sample might reflect oil and gas saturation under conditions of rapid heating and atmospheric pressure. This also shows that the oil shale entered a stage of significant hydrocarbon expulsion, especially in-situ conversion of oil shale under open system. However, there are obvious differences in the $S_{1}$ values and OSI amongst these samples (Table 3). Experiments have shown that kerogen has a significant effect on the oil absorption capacity of mudstone, with type I kerogen having the strongest influence [60-61]. Based on a discrimination diagram for organic matter type, the Minhe oil shale contains type I kerogen, whereas the Huangxian, Junggar, and Meihe oil shales contain type II kerogen (Fig. 11). These accounts for the higher $S_{1}$ value and OSI of the Minhe oil shale compared with the Huangxian and Junggar oil shales. During heating, many cracks are generated that increase the permeability in oil shales [6-8] and, as such, further heating expels the free hydrocarbons and $S_{1}$ gradually decreases. There is also a certain amount of gas generation during this stage, and previous studies of gas from oil shale retorting have shown that the volatiles are dominated by methane and hydrogen. The yields of $\mathrm{C}_{1}-\mathrm{C}_{4}$ alkanes, hydrogen, and carbon monoxide and dioxide also increase linearly with 
heating temperature [47-48, 52-53].

In the final heating stage (VII-VIII) there is essentially no oil and water generation or expelled, but there is a reduction in TOC content and increase in gas loss (Fig. 3; Tables 2 and3). This suggests that no oil, but some non-condensable gas, is produced during this stage. The primary components of the gas do not change significantly in this stage, although more hydrogen sulfide is released [50]. Both the PI-T $\max$ and HI- $\mathrm{T}_{\max }$ plots showed that the samples had entered the dry gas generation phase in this stage (Figs 11 and 12a). The Meihe, Huangxian, and Junggar oil shales produced less gas than the Minhe oil shale during this heating stage (Fig. 3a; Table 2). This is due to the presence of type I kerogen in the Minhe oil shale, which more readily produces gas than type II kerogen at high temperatures.

\subsection{Thermal evolution of organic matter}

Organic matter fluorescence, vitrinite reflectance (Ro), Rock-Eval pyrolysis, and hydrocarbon generation data can reveal the thermal evolution of organic matter [62-67]. The heating of oil shale at low temperatures is a process of rapid catalytic thermal transformation of organic matter at atmospheric pressure.

The products of each heating stage can be used to constrain the thermal evolution of the organic matter in the oil shales. In the first heating stage, water and a small amount of gas were produced, indicating that the organic matter had not entered the stage of large-scale hydrocarbon generation. Ro values of $0.496 \%-0.629 \%$, plots of HI- $\mathrm{T}_{\max }[40,46,48]$ and PI- $\mathrm{T}_{\max }[45]$, and fluorescence changes all indicate that the organic matter transitioned from immature to low mature during this stage (Figs 8, 10, and 11a). During heating from room temperature to $300^{\circ} \mathrm{C}$ the organic matter was in the immature to low-mature stage.

In the second heating stage a large amount of oil and some gas were generated, indicating that the organic matter had entered the large-scale hydrocarbon generation stage. The Ro values varied from $0.737 \%$ to $1.360 \%$. The data for this stage fall in the mature oil window area in both the HI- $\mathrm{T}_{\max }$ and PI-T $\mathrm{T}_{\max }$ plots (Figs 10 and 11a). The lamalginite fluorescence colour changed gradually from light to deep red, indicating that the organic matter was undergoing thermal degradation during hydrocarbon generation. The amount of oil produced during step VI decreased significantly and the lamalginite fluorescence ceased, which suggests that the thermal evolution gradually transitioned from thermal degradation in the hydrocarbon generation stage to thermal pyrolysis in the wet gas generation stage. All of the above observations reveal that during heating from 300 to $475^{\circ} \mathrm{C}$ the organic matter was mainly in the mature stage.

During the final heating stage there was essentially no oil and only some gas expelled, and Ro values increased to $1.488 \%-1.593 \%$. The samples showed no fluorescence (Fig. 8) and data fall in the dry gas window in the HI-T $\mathrm{max}_{\max }$ and PI-T $\max$ plots (Figs 10 and 11a). As such, the organic matter was undergoing thermal pyrolysis in the 
wet-dry gas generation stage, and from 475 to $520^{\circ} \mathrm{C}$ the organic matter was high-mature to over-mature.

With rapid heating, Ro values became more scattered as temperature increased (Table 3). The Ro D-values in one sample increased gradually, which might have been related to rapid and non-uniform heating of organic matter. Similarly, undergeological conditions and for high-Ro samples, the difference between Ro values is relatively large. Despite this, the Ro values still reflect the general trends of the thermal evolution of organic matter.

\subsection{Evolution of hydrocarbon generation potential}

In different heating stages (i.e., thermal evolution of organic matter), the hydrocarbon generation potential underwent systematic changes. Using Ro or $T_{\max }$ values as proxies for the thermal evolution of organic matter, it is evident that the organic matter became more mature during heating. With increasing Ro values, $S_{2}$ values decreased significantly (Fig. 9b), indicating that the hydrocarbon generation potential gradually declined with heating.

The organic matter fluorescence characteristics and plot of $\mathrm{HI}-\mathrm{T}_{\max }$ can reveal the changes in hydrocarbon generation potential during heating. In addition, plots of petroleum potential, (PP; $\left.\mathrm{S}_{1}+\mathrm{S}_{2}\right)$-TOC [68] and HI-TOC [69], are useful in assessing hydrocarbon generation potential. In the first heating stage (room temperature to $300^{\circ} \mathrm{C}$ ) the oil shale contained abundant type I and II kerogen organic matter with strong oil generation ability (Fig. 12). This indicates that the initially heated oil shale samples have a high hydrocarbon generation potential.

During the second heating stage $\left(300-475^{\circ} \mathrm{C}\right)$ the plots of PP-T $\mathrm{T}_{\max }$ and HI-TOC show that with increasing temperature these samples changed from a very good to a fair oil source (Fig. 12). In particular, the hydrocarbon generation potential of the Minhe oil shale containing type I kerogen gradually became similar to that of type II-III kerogen, and type II kerogen showed similar trends (Fig. 11). Notably, the samples still had excellent hydrocarbon generation potential after being heated to $400^{\circ} \mathrm{C}$, which suggests that this temperature was not sufficient to completely expel the generated oil. Tests have shown that when the $S_{2}$ value exceeds $40 \mathrm{mg} / \mathrm{g}$ a sample can be considered an oil shale (oil yield > 3.5 wt. \%) [38, 70-71], which implies that oil shale and shale oil-gas coexist underground when a mudstone is extremely organic-rich and mature (Fig. 13). In general, as the temperature increases further the hydrocarbon generation potential gradually decreases due to the increase in oil and gas production. However, the heated samples still retain a certain amount of hydrocarbons (Fig. 12) and have a good oil and gas generating capacity.

In the final heating stage $\left(475-520^{\circ} \mathrm{C}\right)$ all the parameters show that the hydrocarbon generating potential of the heated oil shale samples was similar to that of type IV kerogen (Fig. 11). At this point the samples became poor oil or gas source rocks with 
almost no hydrocarbon generation potential (Fig. 12). However, a large amount of residual organic carbon with no hydrocarbon generation potential remained (Table 3).

In summary, at atmospheric pressure, a temperature of $\sim 475^{\circ} \mathrm{C}$ results in almost full oil and gas recovery.

\subsection{Implications for in situ conversion of oil shale}

In situ conversion of oil shale underground is a physical and chemical process involving horizontal drilling and electrical heating technology, which can be considered an "underground refinery" [72]. Our experiments were designed to mimic this process (Fig. 13) and obtain the optimum heating temperature of oil shale during in situ conversion (nearly open system). Although hydrocarbon generation will be different in open and confined systems underground, our experiments provide preliminary constraints on the accumulation of unconventional energy sources such as shale oil and gas, and the effect of temperature on their generation.

Oil shale is a sedimentary rock with a high organic matter abundance and shallow burial depth $(<1000 \mathrm{~m})$, which is in the low-mature to immature stage (Fig. 13). The oil shale needs to be heated rapidly to promote hydrocarbon generation and expulsion from the kerogen in the shale.

From room temperature to $300^{\circ} \mathrm{C}($ Ro $<0.63 \%)$, water is the main product. For an oil shale with high water content, a large amount of water is produced during heating, and this water will continue to absorb heat and keep boiling, which hinders further heating of the oil shale. The in situ oil-shale conversation experiment by Jilin University was unsuccessful until the water had been removed from the water-rich oil shale. Therefore, it is suggested that water in water-rich oil shale should be fully removed by heating to $300^{\circ} \mathrm{C}$. During this heating stage, water is gasified and can be discharged in the recovery wells. The discharged gases need to be treated appropriately to avoid environmental pollution.

Oil and gas begin to be produced at $300-400^{\circ} \mathrm{C}(\mathrm{Ro}=0.74 \%-0.78 \%)$, but the organic matter has a high hydrocarbon generation potential and retains hydrocarbons, which is when oil shale and shale oil-gas coexist. Therefore, $400^{\circ} \mathrm{C}$ should not be the final temperature for in situ conversion of oil shale.

During heating from 400 to $475^{\circ} \mathrm{C}$ (Ro $=0.78 \%-1.36 \%$ ), a large amount of hydrocarbons is generated and expelled, and this stage is the shale oil-gas accumulation zone (Fig. 13). When the oil shale is heated to $440^{\circ} \mathrm{C}$, most of the oil is expelled and the retained hydrocarbon content gradually decreases (Fig. 13), which is thus the optimum temperature for in situ conversion of oil shale when taking into account the heating cost and oil yield.

When the heating temperature exceeds $475^{\circ} \mathrm{C}($ Ro $>1.36 \%)$ the organic matter enters 
the wet or dry gas (i.e., shale gas accumulation zone) generation stage. For oil shale containing type II kerogen, the gas production is very low at this heating stage, but for type I kerogen oil shale (e.g., Minhe oil shale) a significant amount of gas is produced. Accordingly, it is suggested that the final in situ conversion heating temperature of type I kerogen oil shale should be slightly higher than for type II kerogen oil shale.

The discussion above is based only on laboratory experiments, and the effects of heating time, particle size, system closure, water saturation, pressure, heating rate, environmental issues and other factors on organic matter thermal evolution and low-temperature products have not been taken into account. In fact, few studies have been conducted on the thermal evolution and hydrocarbon generation characteristics of organic matter based on in situ oil shale conversion experiments in the field. The in situ oil shale conversion techniques of Jilin University and the Zhongcheng Group (China) have suggested the heating temperature should exceed $400^{\circ} \mathrm{C}$. A higher heating temperature results in greater costs, but a shorter heating time can also reduce costs. The economic significance of the heating temperature and time needs to be evaluated in pilot field tests. In situ conversion of oil shale is a long-term and complex process and requires further geological, environmental problems and technological investigations to be able to properly exploit this resource.

\section{Conclusions}

Oil shale is an important unconventional energy source that requires in situ conversion. Our heating experiments on oil shales have identified the products of different heating stages, thermal evolution of organic matter, and optimum temperature for rapid hydrocarbon generation during in situ conversion of oil shale.

During the first heating stage (room temperature to $300^{\circ} \mathrm{C}$ ) the main products were water and a small amount of gas, and the organic matter had a high hydrocarbon generation potential and was immature to low-mature.

In the second heating stage $\left(300^{\circ} \mathrm{C}-475^{\circ} \mathrm{C}\right)$, oil and gas were mainly produced, which represents the oil generation window for oil shale under conditions of atmospheric pressure and rapid heating. In particular, $400-440^{\circ} \mathrm{C}$ was the optimum temperature interval for oil generation, in which the organic matter entered the mature stage. Even after heating to $400^{\circ} \mathrm{C}$ the oil shale expelled a large amount of oil and gas, and the organic matter still had a high hydrocarbon generation potential. Subsequently, the hydrocarbon generation potential gradually decreased. In our experiments the $S_{1}$ peak is considered to represent the maximum oil and gas saturation. The maximum OSI is much larger for type I kerogen oil shale than for type II kerogen oil shale.

In the final heating stage $\left(475^{\circ} \mathrm{C}-520^{\circ} \mathrm{C}\right)$ a small amount of gas was expelled and the organic matter has almost no hydrocarbon generation potential and is high-mature or over-mature. A large amount of residual organic carbon remained in the final heated samples. 
These oil shale experiments provide constraints on the in situ conversion of oil shale to shale oil-gas, and then to shale gas, during the thermal evolution of organic matter. Our results suggest that water (oil shale with high water content) should be removed by heating to $300^{\circ} \mathrm{C}$ and that the final temperature for in situ conversion is $440^{\circ} \mathrm{C}$ (but slightly higher for oil shale containing type I kerogen). These constraints need pilot field testing to be optimized.

\section{Acknowledgements}

The research project was financially supported by the National Natural Science Fund (41772092 and 41402088), the Science and Technology Development Plan of Jilin Province (20150520070JH and 20180201077SF).Three anonymous reviewer greatly helped to improve the paper.

\section{References:}

[1] Dyni, J.R., 2006. Geology and resources of some world oil shale deposits. US Geological Survey Scientific Investigations.

[2] Han, X.X., Kulaots, I., Jiang, X.M., Suuberg, E.M., 2014. Review of oil shale semicoke and its combustion utilization. Fuel. 126(12), 143-161.

[3] Velts, O., Uibu, M., Rudjak, I., Kallas, J., Kuusik, R., 2009. Utilization of oil shale ash to prepare PCC: leachibility dynamics and equilibrium in the ash-water system. Energy Procedia. 1(1), 4843-4850.

[4] Trikkela, A., Kuusik, R., Martins, A., Pihu, T., Stencel, J.M., 2008. Utilization of Estonian oil shale semicoke. Fuel Processing Technology. 89(8), 756-763.

[5] Jiang, X.M., Han, X.X., Cui, Z.G., 2006. New technology for the comprehensive utilization of Chinese oil shale resources. Energy. 32(5), 772-777.

[6] Bai, F.T., Sun, Y.H., Liu, Y.M., Guo, M.Y., 2016. Evaluation of the porous structure of Huadian oil shale during pyrolysis using multiple approaches. Fuel. $187,1-8$.

[7] Burnham, A.K., 2017. Porosity and permeability of Green River oil shale and their changes during retorting. Fuel. 203, 208-213.

[8] Saif, T., Lin, Q.Y., Butcher, A.R., Bijeljic, B., Blunt, M.J., 2017. Multi-scale multi-dimensional microstructure imaging of oil shale pyrolysis using X-ray micro-tomography, automated ultra-high resolution SEM, MAPS Mineralogy and FIB-SEM. Applied Energy. 202, 628-647.

[9] Burnham, A.K., Mcconaghy, J.R., 2014. Semi-Open pyrolysis of oil shale from the Garden Gulch Member of the Green River Formation. Energy \& Fuels. 28(12), 7426-7439.

[10] Na, J.G., Im, C.H., Chung, S.H., Lee, K.B., 2012. Effect of oil shale retorting temperature on shale oil yield and properties. Fuel. 95, 131-135.

[11] Mclendon, T.R., 1984. Evaluation of oil yield losses during the retorting of oil shale at low void fractions. Part 1. the effects of particle size and resource grade. Liq. Fuels Technol (United States). 2:4(2), 439-461.

[12] Lewis, A.E., Braun, R.L., 1981. Retorting and combustion processes in surface 
oil-shale retorts. Journal of Energy. 5(6), 355-361.

[13] Evans, R.A., Campbell, J.H., 1979. Oil shale retorting - A correlation of selected infrared absorbance bands with process heating rates and oil yield. Situ. 3, 33-51.

[14] Campbell, J.H., Koskinas, G.H., Stout, N.D., Coburn, T.T., 1978. Oil shale retorting - effects of particle size and heating rate on oil evolution and intraparticle oil degradation. Situ. 2(1), 1-47.

[15] Ho, C.H., Clark, B.R., Guerin, M.R., 1976. Direct analysis of organic compounds in aqueous by-products from fossil fuel conversion processes: Oil shale retorting, synthane coal gasification and coed coal liquefaction. Journal of Environmental Science and Health. Part A: Environmental Science and Engineering. 11(7), 481-489.

[16] Burnham A., K., 1995. Chemical kinetics and oil shale process design// Composition, Geochemistry and Conversion of Oil Shales.

[17] Burnham A. K., Ethan B. H., Mary F. S., 1983. Pyrolysis kinetics for Green River oil shale from the saline zone. Fuel. 62(10):1199-1204.

[18] Burnham A. K., 1981. Reaction kinetics and diagnostics for oil-shale retorting. Nasa Sti/recon Technical Report N, 83.

[19] Tiwari P, Milind Deo, 2012. Detailed kinetic analysis of oil shale pyrolysis TGA data. Aiche Journal. 58(2):505-515.

[20] Lee S., Speight, J.G., Loyalka, S.K., 2014. Handbook of Alternative Fuel Technologies, Second Edision. Crc Press.

[21] Speight, J.G., 1990. Fuel Science and Technology Handbook. New York, NY (USA). Marcel Dekker Inc.

[22] Speight, J.G., 2012. Chapter 5-In Situ Retorting. in: Speight JG (Ed.) Shale Oil Production Processes, Gulf Professional Publishing, Boston. 123-138.

[23] Brandt, A.R., 2008. Converting Oil Shale to Liquid Fuels: Energy Inputs and Greenhouse Gas Emissions of the Shell in Situ Conversion Process. Environmental Science \& Technology. 42, 7489-7495.

[24] Fowler, T.D., Vinegar, H.J., 2009. Oil shale ICP-Colorado field pilots. Paper SPE 121164 presented at the SPE Western Regional Meeting, San Jose, California, USA.

[25] Harold, V., 2006. Shell's In Situ Conversion Process. 26th Oil Shale Symposium. Colorado. 16-19.

[26] Crawford, P.M., Biglarbigi, K., Killen, J.R., Dammer, A.R., 2008. Knaus E. "Advances in world oil-shale production technologies". Society of Petroleum Engineers Annual Technical Conference and Exhibition. Denver, Colorado: Society of Petroleum Engineers.

[27] French, G.B., Bartel, W.J., Ridley, R.D., Cha, C.Y., Burton, Iii, R.S., 1997. System for fuel and products of oil shale retort. US, US4014575.

[28] Cha, C.Y., 1977. Method of igniting in situ oil shale retort with fuel rich flue gas. US, US4005752 A.

[29] Burton-Iii, R.S., Cha, C.Y., Ridley, R.D., 1976. Apparatus for obtaining uniform gas flow through an in situ oil shale retort. US, US3941421.

[30] Cook, E.W., 1974. Oil-shale technology in the USA. Fuel. 53, 146-151. 
[31] Zhao, J.M., 2017. Method and process for extracting shale oil and gas by fracturing and chemical retorting in oil shale in-situ horizontal well. U.S. Patent. 9, 784, 086, B2.

[32] Sun, Y. H., Bai, F. T., Lü, X. S., Li, Q., Liu, Y. M., Guo, M. Y., Guo, W., Liu, B. C., 2015. A novel energy-efficient pyrolysis process: self-pyrolysis of oil shale triggered by topochemical heat in a horizontal fixed bed. Sci Rep.5(8290): 1-8

[33]Sun, P. C., 2013. Environmental Dynamics of Organic Accumulation in the Oil Shale Bearing Layers in the Upper Cretaceous, Southeast Songliao Basin (NE China). PhD Thesis, Changchun, Jilin University, 208 pp (in Chinese with English abstract).

[34] Xu, J. J., Liu, Z. J., Bechtel, A., Meng, Q. T., Sun, P. C., Jia, J. L., Cheng, L. J., Song, Y., 2015. Basin evolution and oil shale deposition during Upper Cretaceous in the Songliao Basin (NE China): Implications from sequence stratigraphy and geochemistry. Int. J. Coal Geol. 149, 9-23.

[35] Liu, Z.J., Meng, Q.T., Dong, Q. S., Zhu, J. W., Guo, W., Ye, S. Q., Liu, R., Jia, J. L., 2017. Characteristics and resource potential of oil shale in China. Oil Shale. $34,15-41$.

[36] Tao, S., Tang, D. Z., Xu, H., Liang, J. L., Shi, X. F., 2013. Organic geochemistry and elements distribution in dahuangshan oil shale, southern junggar basin: origin of organic matter and depositional environment. International Journal of Coal Geology, 115(8), 41-51.

[37] Lv, D. W, Zong, R. F., Li, Z. X., Wang, D. D., Liu, H. Y., Wu, X. Y., Wang, X. B., Yu, D. M., Feng, T. T., Zhao, L. Y., Yang, Q., Yong, P. L., 2016. Oil shale paleo-productivity disturbed by sea water in a coal and oil shale bearing succession: A case study from the Paleogene Huangxian basin of Eastern China. Journal of Petroleum Science and Engineering. 139, 62-70.

[38]Bai Y. Y., Liu Z. J., Sun P. C., Liu R., Hu X. F., Zhou R. J., Xu Y. B., Zhao H. Q., Wang J. P., 2017. Diverse sedimentary conditions during deposition of coal and oil shale from the Meihe Basin (Eocene, ne China). Journal of Sedimentary Research. 87(10):1100-1120

[39] Liu, Z. J., Sun, P. C., Liu, R., Meng, Q. T., Hu, F., 2016. Genetic types and deposits feature of oil shale in continental basin in China. Journal of Palaeogeography. 18(4), 525-534 (in Chinese with English abstract).

[40] Espitalié, J., Laporte, J.L., Madec, M., Marquis, F., Leplat, P., Paulet, J., Boutefeu, A., 1977. Méthode rapide de caractérisation des roches mères, de leur potentiel pétrolier et de leur degré d'évolution. Revue de l' Institut Francais du Pétrole. 32, 23-42.

[41]Lafargue E, Marquis F, Pillot D. 1998. Rock-Eval 6 applications in hydrocarbon exploration, production and soil contamination studies. Revue de l'Institut français du Pétrole 53(4): 421-437.

[42] Hutton, A.C., 1987. Petrolographic classification of oil shales. International Journal of Coal Geology 8, 203-231.

[43]Wang, Q., Xu, X.C., Chi, M.S., Zhang, H.X., Cui, D., Bai, J.R., 2015. FT-IR study on composition of oil shale kerogen and its pyrolysis oil generation 
characteristics. Journal of Fuel Chemistry and Technology. 43(10), 1158-1166 (in Chinese with English abstract).

[44]Ishiwatari, R., Ishiwatari, M., Rohrback, B.G., Kaplan, I.R., 1977. Thermal alteration experiments on organic matter from recent marine sediments in relation to petroleum genesis. J. Geochimica Et Cosmochimica Acta. 41(6), 815-828.

[45] Waples, D.W., 1985. Geochemistry in Petroleum Exploration. International Human Resources Development Corporation. Boston, p 232.

[46] Espitalié, J., Marquis, F., Barsony, I., 1984. Geochemical logging. In: Voorhess, K.J. (Ed.), Analytical Pyrolysis. Butterworths, Boston, pp. 53-79.

[47] Langford, F.F., Blanc-Valleron, M.M., 1990. Interpreting Rock-Eval pyrolysis data using graphs of pyrolyzable hydrocarbons vs. total organic carbon. AAPG Bulletin. 74, 799-804.

[48] Tyson, R., 1995. Abundance of organic matter in sediments. TOC, hydrodynamic equivalence, dilution and flux effects. Sediment. Organ. Matter Organ. Facies Palynofacies. 81-118.

[49] Wang, W., Ma, Y., Li, S.Y., Yue, C.T., Wu, J.X., Teng, J.S., 2016. Pyrolysis characteristics of Longkou oil shale under optimized condition. J. Journal of Thermal Analysis and Calorimetry. 125(2), 983-990.

[50] Lan, X.Z., Luo, W.J., Song, Y.H., Zhou, J., Zhang, Q.L., 2015. Effect of the Temperature on the Characteristics of Retorting Products Obtained by Yaojie Oil Shale Pyrolysis. Energy \& Fuels. 29,7800-7806.

[51] Wang, S., Jiang, X., Han, X., Tong, J.H., 2013. Effect of residence time on products yield and characteristics of shale oil and gases produced by low-temperature retorting of Dachengzi oil shale. Oil Shale. 30(4), 501-516.

[52] Wang, S., Jiang, X., Han, X., Tong, J.H., 2014. Effect of retorting temperature on product yield and characteristics of non-condensable gases and shale oil obtained by retorting Huadian oil shales. Fuel Processing Technology. 121(1), 9-15.

[53] Dung, N.V., 1990. Yields and chemical characteristics of products from fluidized bed steam retorting of Condor and Stuart oil shales: effect of pyrolysis temperature. Fuel. 69(3), 368-376.

[54] Niu, M.T., Wang, S., Han, X.X., Jiang, X.M., 2013. Yield and characteristics of shale oil from the retorting of oil shale and fine oil-shale ash mixtures. Applied Energy. 111(11), 234-239.

[55] Ramachandran, K., Babu, V., Behera, B.K., Harinarayana, T., 2013. Source rock analysis, thermal maturation and hydrocarbon generation using rock-eval pyrolysis in parts of Krishna-Godavari basin, India: a case study. Journal of Petroleum Exploration and Production Technology. 3(1), 11-20.

[56] Lu, S.F., Huang, W.B., Chen, F.W., Li, J.J., Wang, M., Xue, H.T., Wang, M.M., Cai, X.Y., 2012. Classification and evaluation criteria of shale oil and gas resources: Discussion and application. Petroleum Exploration and Development. 39(2), 268-276.

[57] Hunt, J., 1996. Petroleum Geochemistry and Geology (A Series of books in geology). M. Petroleum geochemistry and geology, p 743. 
[58] Delvaux, D., Martin, H., Leplat, P., Paulet, J., 1990. Comparative rock-eval pyrolysis as an improved tool for sedimentary organic-matter analysis. Organic Geochemistry. 16(4), 1221-1229.

[59] Jarvie, D.M., 2012. Shale resource systems for oil and gas: part1-shalegas resource systems. M. //BREYER J A.Shale reservoirs-Giant resources for the 21st Century. AAPG Memoir97.Tulsa. American Association of Petroleum Geologists. 69-87.

[60] Kelemen, S. R., Walters, C.C., Ertas, D., Kwiatek, L.M., \& Curry, D.J., 2006. Petroleum Expulsion Part 2. Organic Matter Type and Maturity Effects on Kerogen Swelling by Solvents and Thermodynamic Parameters for Kerogen from Regular Solution Theory. Energy \& Fuels. 20(1), 301-308.

[61] Ritter, U., 2003. Fractionation of petroleum during expulsion from kerogen. Journal of Geochemical Exploration. 78(8), 417-420.

[62] Cheshire, S., Craddock, P.R., Xu, G.P., 2017. Assessing thermal maturity beyond the reaches of vitrinite reflectance and Rock-Eval pyrolysis: A case study from the Silurian Qusaiba Formation. International Journal of Coal Geology. 180.

[63] Kalkreuth, W., Sherwood, N., Cioccari, G., Silva, Z. C. D., Silva, M., Zhong, N., Zufa, L., 2004. The application of famm ${ }^{\mathrm{TM}}$ (fluorescence alteration of multiples macerals) analyses for evaluating rank of parana basin coals, brazil. International Journal of Coal Geology. 57(3), 167-185.

[64] Stasiuk. L.D., Lockhart, G.D., Nassichuk, W.W., Carlson, J.A., 1999. Thermal maturity evaluation of dispersed organic matter inclusions from kimberlite pipes, Lac de Gras, Northwest Territories, Canada. International Journal of Coal Geology. 40(1), 1-25.

[65] Pradier, B., Bertrand, P., Martinez, L., Laggoun-Defarge, F., 1991. Fluorescence of organic matter and thermal maturity assessment. Organic Geochemistry. 17(4), 511-524.

[66] Tissot, B.P., Welte, D.H., 1984. Petroleum Formation and Occurrence. M. // Petroleum formation and occurrence.

[67] Staplin, F.L., 1977. Interpretation of thermal history from color of particulate organic matter - A review. Palynology. 1(1), 9-18

[68] Peters, K.E., 1986. Guidelines for evaluating petroleum source rock using programmed pyrolysis. AAPG Bull. 70, 318-329.

[69] Jackson, K.S., Hawkins, P.J., Bennett, A.R.J., 1980. Regional facies and geochemical evaluation of the southern Denison Trough, Queensland. APPEA J. 20, 143-158.

[70] Sun, P.C., Sachsenhofer, R.F., Liu, Z.J., Strobl, S.A.I., Meng, Q.T., Liu, R., Zhen, Z., 2013a. Organic matter accumulation in the oil shale- and coal-bearing Huadian Basin (Eocene; NE China). International Journal of Coal Geology. 106, $1-15$.

[71] Sun, P.C., Liu, Z.J., Gratzer, R., Xu, Y.B., Liu, R., Li, B.Y., Meng, Q.T., Xu, J.J., 2013b. Oil yield and bulk geochemical parameters in the Songliao and Huadian Basins (China). a grade classification approach. Oil shale. 30(3), 402-418.

[72] Zhao, W.Z., Hu, S.Y., Hou, L.H., 2018. Connotation and strategic role of in-situ 
conversion processing of shale oil underground in the onshore China. Petroleum Exploration and Development. 45(4), 563-572. 


\section{Figure captions}

Fig.1. Sample locations and distribution of oil-shale-bearing basins in China.

Fig. 2. Schematic chart of oil shale heating. (1) Aluminium retort, (2)Heating furnace,

(3) Outlet pipe, (4) Thermocouple, (5) Cold junction thermostat, (6)

Electriccabinet, (7) Receiver, (8) Colling tank, (9) Absorbent cotton, (10)

Condenser pipe, (11)Water determination pipe, (12) Heating platform, (13) Oil

Shale

L-Low temperature carbonization of oil shale, R-Oil-water separation measuring device

Fig. 3.Variation in the low-temperature products generated from the four oil shale samples in the different heating steps. a. Oil yields and gas and weight loss changes in the different heating steps. b. Variations in the semi-coke contents in the different heating steps.

Fig. 4. Changes in the TOC contents of the four oil shale samples in each heating step. a. The residual TOC contents of the four samples at each heating step. b. A plot of oil yields versus TOC contents for the original and heated samples.

Fig. 5. Variations of the sample pyrolysis parameters in each heating step. a. S1 and $\mathrm{S} 2$ values in the different heating steps. b. Variations of PI and $\mathrm{T}_{\max }$ values in the different heating steps.

Fig. 6. Relationship between S2 values and TOC contents in each heating step.

Fig. 7. Plots of $\mathrm{T}_{\text {peak }}$ and $\mathrm{S} 2$ abundances for the Meihe oil shale samples in each heating step. $\mathrm{T}_{\max }=\mathrm{T}_{\text {peak }}-39^{\circ} \mathrm{C}$.

Fig.8. Maturity parameter distributions and white light and fluorescence microscopy images after each heating step. The Meihe oil shale samples were selected for Ro testing and vitrinite characterization. $\mathrm{T}_{\max }$ and PI values were also obtained from the Meihe samples. The Minhe oil shale samples were used for maceral observations. a)- i) with the increase of heating temperature, vitrinite colour changes from grey to bright white, and these photomicrograohs were taken using a 50× oil immersion objective under white light. j)-k) A high concentration of lamalginite; 1) Pale red on lamalginite edges; m) Red on whole lamalginite; n) The single lamalginite is invisible; o) Exsudatinite with a strong fluorescence, and lamalginiteonly scattered fluorescent spots remained; p) Only exsudatinite with fluorescence; q) Rare fluorescent exsudatinite remained; r) All organic macerals without fluorescence. All photomicrograohs (j-r) were taken using a 50x oil immersion objective under UV light.

Fig. 9. Plots of Ro values versus oil yields, gas loss, TOC contents, and $\mathrm{S}_{2}$ values.

Fig. 10. Plot of PI versus $T_{\max }$ values for each heating step. The diagram is based on reference [45]. 
Fig. 11. Organic matter discrimination diagram showing data for each heating step. The diagrams are based on references[40, 46-48].

Fig. 12. Plots of the hydrocarbon generation ability of the samples at each heating step. The diagrams are based on references [68-69].

Fig. 13. Model of hydrocarbon generation, oil and gas expulsion, and retained hydrocarbons during the retorting process. A schematic representation of unconventional hydrocarbon accumulation is also shown (modified after reference[66]). 
Table 1. Basic information about oil shale samples

\begin{tabular}{|c|c|c|c|c|c|}
\hline Basins & Location & Era & Oil shale features & $\begin{array}{c}\text { Oil shale bearing } \\
\text { layers }\end{array}$ & $\begin{array}{l}\text { Sedimentary } \\
\text { environment }\end{array}$ \\
\hline $\begin{array}{l}\text { Huang- } \\
\text { xian }\end{array}$ & E, China & $\begin{array}{l}\text { Huangxian } \\
\text { Formation in } \\
\text { Paleogene }\end{array}$ & $\begin{array}{l}\text { well-bedded and } \\
\text { brown in colour }\end{array}$ & $\begin{array}{c}\text { oil shale and } \\
\text { interbeddedcoal } \\
\text { deposited }\end{array}$ & $\begin{array}{c}\text { Lacustrine-swampy } \\
\text { environment }\end{array}$ \\
\hline Minhe & $\begin{array}{l}\text { NW, } \\
\text { China }\end{array}$ & $\begin{array}{c}\text { Yaojie Formation } \\
\text { in Middle } \\
\text { Jurassic }\end{array}$ & $\begin{array}{l}\text { well-bedded and } \\
\text { greyish brown in } \\
\text { colour }\end{array}$ & $\begin{array}{c}\text { oil shale, } \\
\text { interbeddeddark } \\
\text { mudstone and coal } \\
\text { deposited }\end{array}$ & $\begin{array}{c}\text { Lacustrine-swampy } \\
\text { and deep lake } \\
\text { environment }\end{array}$ \\
\hline Junggar & $\begin{array}{l}\text { NW, } \\
\text { China }\end{array}$ & $\begin{array}{c}\text { Lucaogou } \\
\text { Formation in } \\
\text { Upper Permian }\end{array}$ & $\begin{array}{c}\text { well-bedded and } \\
\text { dark grey in colour }\end{array}$ & $\begin{array}{c}\text { oil shale and } \\
\text { interbedded dark } \\
\text { mudstone deposited }\end{array}$ & $\begin{array}{c}\text { Deep lake } \\
\text { environment }\end{array}$ \\
\hline Meihe & $\begin{array}{l}\text { NE, } \\
\text { China }\end{array}$ & $\begin{array}{l}\text { Meihe Formation } \\
\text { in Paleogene }\end{array}$ & $\begin{array}{l}\text { Lack of bedding } \\
\text { structure and dark } \\
\text { grey in colour }\end{array}$ & $\begin{array}{c}\text { oil shale and } \\
\text { interbeddedcoal } \\
\text { deposited }\end{array}$ & $\begin{array}{c}\text { Lacustrine-swampy } \\
\text { and deep lake } \\
\text { environment }\end{array}$ \\
\hline
\end{tabular}


Table 2.Characteristics of the low-temperature products generated from the oil shale samples after the different heating steps.

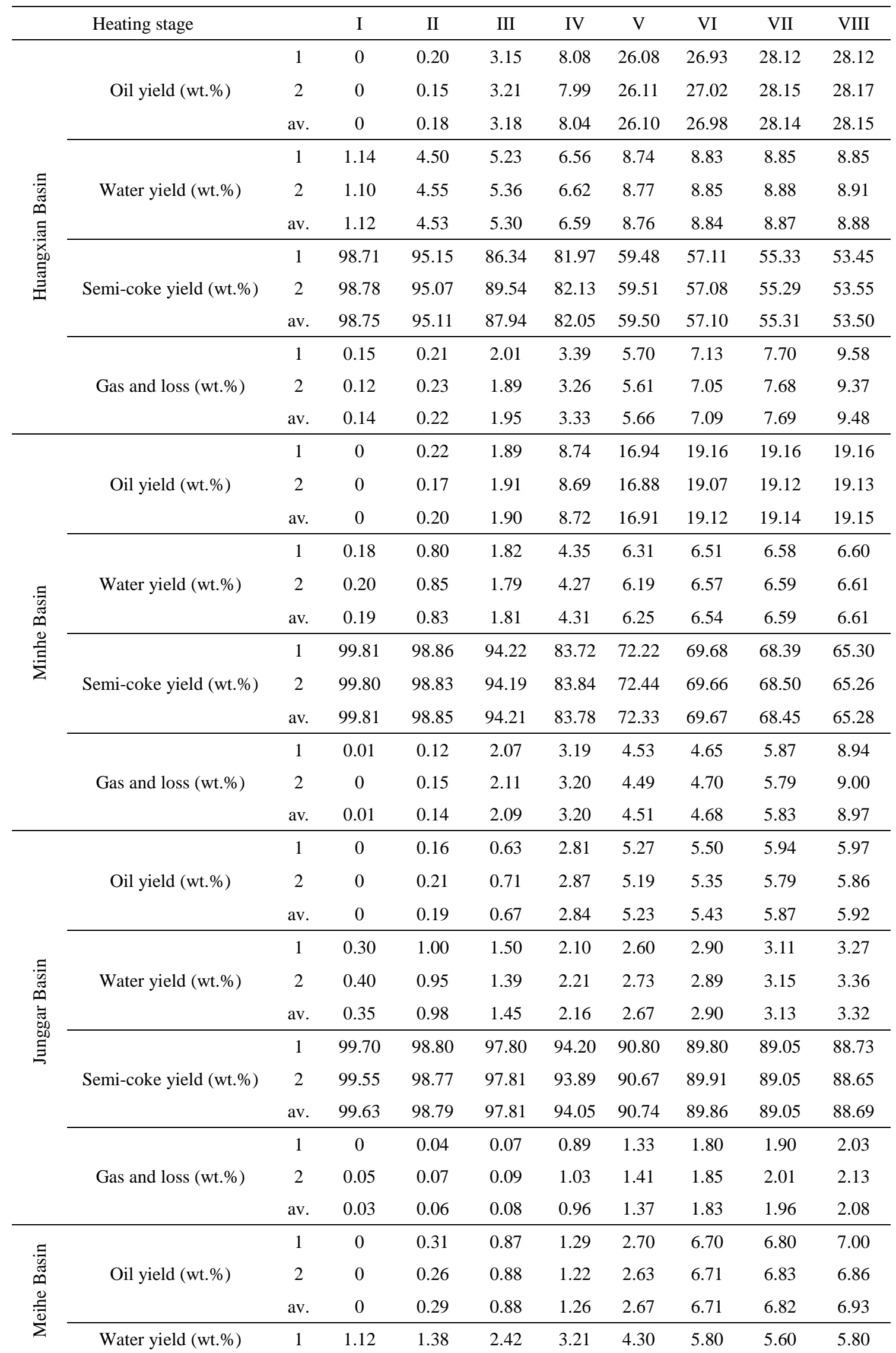




\begin{tabular}{cccccccccc} 
& 2 & 1.09 & 1.41 & 2.33 & 3.16 & 4.27 & 5.73 & 5.59 & 5.71 \\
& av. & 1.11 & 1.40 & 2.38 & 3.19 & 4.29 & 5.77 & 5.60 & 5.76 \\
\hline \multirow{3}{*}{ Semi-coke yield (wt.\%) } & 1 & 98.83 & 98.04 & 96.22 & 94.35 & 91.51 & 83.29 & 81.35 & 80.80 \\
& 2 & 98.84 & 98.03 & 96.27 & 94.45 & 91.58 & 83.43 & 81.28 & 81.08 \\
& av. & 98.84 & 98.04 & 96.25 & 94.40 & 91.55 & 83.36 & 81.32 & 80.94 \\
\hline \multirow{3}{*}{ Gas and loss (wt.\%) } & 1 & 0.05 & 0.27 & 0.49 & 1.15 & 1.49 & 4.21 & 6.25 & 6.40 \\
& 2 & 0.07 & 0.30 & 0.52 & 1.17 & 1.52 & 4.13 & 6.30 & 6.35 \\
& av. & 0.06 & 0.29 & 0.51 & 1.16 & 1.51 & 4.17 & 6.28 & 6.38 \\
\hline
\end{tabular}


Table 3. TOC contents and Rock-Eval pyrolysis parameters of the oil shale samples after the different heating steps.

\begin{tabular}{|c|c|c|c|c|c|c|c|c|c|c|c|c|c|c|c|c|c|c|c|c|c|}
\hline \multirow{3}{*}{\multicolumn{2}{|c|}{$\begin{array}{l}\text { Huangxian } \\
\text { Samples }\end{array}$}} & \multirow{2}{*}{\multicolumn{3}{|c|}{$\begin{array}{l}\text { TOC } \\
\text { (wt.\%) }\end{array}$}} & \multicolumn{3}{|c|}{ S1 } & \multicolumn{3}{|c|}{$\mathrm{S} 2$} & \multicolumn{3}{|c|}{ S3 } & \multirow{3}{*}{$\begin{array}{c}\mathrm{S} 1+\mathrm{S} 2 \\
\text { av. } \\
\end{array}$} & \multirow{2}{*}{\multicolumn{3}{|c|}{$\begin{array}{l}\text { Tmax } \\
\left({ }^{\circ} \mathrm{C}\right)\end{array}$}} & \multirow{3}{*}{ PI } & $\mathrm{HI}$ & OI & \multirow{3}{*}{ OSI } \\
\hline & & & & & \multicolumn{9}{|c|}{$(\mathrm{mg} / \mathrm{g})$} & & & & & & \multirow{2}{*}{\multicolumn{2}{|c|}{ (mg HC/g TOC) }} & \\
\hline & & 1 & 2 & av. & 1 & 2 & av. & 1 & 2 & av. & 1 & 2 & av. & & 1 & 2 & av. & & & & \\
\hline \multicolumn{2}{|c|}{ OS } & 56.73 & 55.97 & 56.35 & 3.42 & 3.17 & 3.30 & 293.99 & 291.68 & 292.84 & 1.39 & 1.57 & 1.48 & 296.13 & 437 & 436 & 437 & 0.01 & 516 & 2.6 & 5.85 \\
\hline \multirow{8}{*}{ 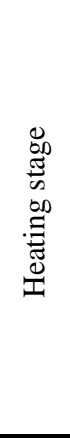 } & I & 56.92 & 56.81 & 56.87 & 5.2 & 5.08 & 5.14 & 294.16 & 290.57 & 292.37 & 2.21 & 2.36 & 2.29 & 297.51 & 439 & 438 & 439 & 0.02 & 514 & 4.0 & 9.04 \\
\hline & II & 55.76 & 55.32 & 55.54 & 5.52 & 5.56 & 5.54 & 275.18 & 273.59 & 274.39 & 1.72 & 1.93 & 1.83 & 279.93 & 439 & 440 & 440 & 0.02 & 492 & 3.3 & 9.97 \\
\hline & III & 52.45 & 52.03 & 52.24 & 6 & 6.02 & 6.01 & 233.4 & 233.12 & 233.26 & 1.66 & 1.76 & 1.71 & 239.27 & 440 & 441 & 441 & 0.03 & 445 & 3.3 & 11.50 \\
\hline & IV & 46.91 & 46.95 & 46.93 & 7.75 & 7.83 & 7.79 & 171.01 & 169.87 & 170.44 & 1.74 & 1.68 & 1.71 & 178.23 & 442 & 442 & 442 & 0.04 & 363 & 3.6 & 16.60 \\
\hline & $\mathrm{V}$ & 41.47 & 40.99 & 41.23 & 5.52 & 5.49 & 5.51 & 129.61 & 127.56 & 128.59 & 1.56 & 1.77 & 1.67 & 134.09 & 448 & 448 & 448 & 0.04 & 310 & 4.0 & 13.35 \\
\hline & VI & 33.3 & 33.1 & 33.20 & 4.54 & 4.38 & 4.46 & 31.22 & 29.58 & 30.40 & 2.21 & 2.36 & 2.29 & 34.86 & 532 & 526 & 529 & 0.13 & 91 & 6.9 & 13.43 \\
\hline & VII & 32.95 & 32.57 & 32.76 & 4.45 & 4.15 & 4.30 & 15.24 & 14.78 & 15.01 & 1.86 & 1.99 & 1.93 & 19.31 & 570 & 575 & 573 & 0.22 & 46 & 5.9 & 13.13 \\
\hline & VIII & 29.35 & 29.2 & 29.28 & 2.27 & 1.98 & 2.13 & 8.54 & 7.89 & 8.22 & 1.14 & 1.25 & 1.20 & 10.34 & 598 & 608 & 603 & 0.21 & 28 & 4.1 & 7.26 \\
\hline \multirow{3}{*}{\multicolumn{2}{|c|}{$\begin{array}{c}\text { Minhe } \\
\text { Samples }\end{array}$}} & & TOC & & & S1 & & & $\mathrm{S} 2$ & & & S3 & & $\mathrm{S} 1+\mathrm{S} 2$ & & Tmax & & & HI & OI & \\
\hline & & & (wt.\%) & & \multicolumn{10}{|c|}{$(\mathrm{mg} / \mathrm{g})$} & \multicolumn{3}{|c|}{$\left({ }^{\circ} \mathrm{C}\right)$} & PI & \multirow{2}{*}{\multicolumn{2}{|c|}{ (mg HC/g TOC) }} & OSI \\
\hline & & 1 & 2 & av. & 1 & 2 & av. & 1 & 2 & av. & 1 & 2 & av. & av. & 1 & 2 & av. & & & & \\
\hline \multicolumn{2}{|c|}{ OS } & 41.3 & 42.5 & 41.90 & 5.43 & 5.68 & 5.56 & 289.26 & 290.73 & 290.00 & 2.11 & 1.98 & 2.05 & 295.55 & 433 & 434 & 434 & 0.02 & 702 & 4.9 & 13.26 \\
\hline \multirow{7}{*}{ 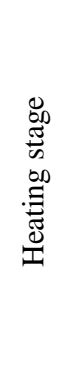 } & I & 41.6 & 42.65 & 42.13 & 4.72 & 4.93 & 4.83 & 288.26 & 291.15 & 289.71 & 1.78 & 1.89 & 1.84 & 294.53 & 435 & 435 & 435 & 0.02 & 696 & 4.4 & 11.45 \\
\hline & II & 39.9 & 40.01 & 39.96 & 4.95 & 4.89 & 4.92 & 271.55 & 273.05 & 272.30 & 1.49 & 1.76 & 1.63 & 277.22 & 436 & 437 & 437 & 0.02 & 682 & 4.1 & 12.31 \\
\hline & III & 37.8 & 38.5 & 38.15 & 10.8 & 9.95 & 10.38 & 250.37 & 251.18 & 250.78 & 1.32 & 1.34 & 1.33 & 261.15 & 436 & 437 & 437 & 0.04 & 663 & 3.5 & 27.20 \\
\hline & IV & 36.65 & 37.62 & 37.14 & 14.61 & 14.74 & 14.68 & 223.56 & 222.06 & 222.81 & 3.46 & 3.78 & 3.62 & 237.49 & 437 & 438 & 438 & 0.06 & 608 & 9.7 & 39.52 \\
\hline & $\mathrm{V}$ & 34.55 & 34.96 & 34.76 & 13.94 & 13.88 & 13.91 & 191.12 & 190.03 & 190.58 & 1.69 & 1.72 & 1.71 & 204.49 & 440 & 441 & 441 & 0.07 & 552 & 4.9 & 40.02 \\
\hline & VI & 27.7 & 27.65 & 27.68 & 5.47 & 6.79 & 6.13 & 26.32 & 27.13 & 26.73 & 2.02 & 2.12 & 2.07 & 32.86 & 443 & 443 & 443 & 0.19 & 96 & 7.5 & 22.15 \\
\hline & VII & 25.35 & 24.98 & 25.17 & 6.99 & 5.95 & 6.47 & 8.08 & 7.86 & 7.97 & 0.45 & 0.56 & 0.51 & 14.44 & 563 & 578 & 571 & 0.45 & 31 & 2.0 & 25.71 \\
\hline
\end{tabular}




\begin{tabular}{|c|c|c|c|c|c|c|c|c|c|c|c|c|c|c|c|c|c|c|c|c|c|}
\hline & VIII & 24.25 & 24.63 & 24.44 & 3.98 & 3.47 & 3.73 & 4.06 & 3.45 & 3.76 & 1.36 & 1.47 & 1.42 & 7.48 & 594 & 589 & 592 & 0.50 & 15 & 5.8 & 15.24 \\
\hline \multirow{3}{*}{\multicolumn{2}{|c|}{$\begin{array}{l}\text { Junggar } \\
\text { Samples }\end{array}$}} & & TOC & & & S1 & & & $\mathrm{S} 2$ & & & S3 & & $\mathrm{S} 1+\mathrm{S} 2$ & & $\operatorname{Tmax}$ & & \multirow{3}{*}{ PI } & $\mathrm{HI}$ & OI & \multirow{3}{*}{ OSI } \\
\hline & & \multicolumn{3}{|c|}{ (wt.\%) } & \multicolumn{10}{|c|}{$(\mathrm{mg} / \mathrm{g})$} & \multicolumn{3}{|c|}{$\left({ }^{\circ} \mathrm{C}\right)$} & & \multirow{2}{*}{\multicolumn{2}{|c|}{ (mg HC/g TOC) }} & \\
\hline & & 1 & 2 & av. & 1 & 2 & av. & 1 & 2 & av. & 1 & 2 & av. & av. & 1 & 2 & av. & & & & \\
\hline \multicolumn{2}{|c|}{ OS } & 14.45 & 14.6 & 14.53 & 0.92 & 1.13 & 1.03 & 73.46 & 74.65 & 74.06 & 1.03 & 1.15 & 1.09 & 75.08 & 441 & 442 & 442 & 0.01 & 512 & 7.5 & 7.06 \\
\hline \multirow{8}{*}{ 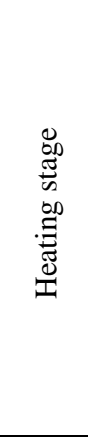 } & I & 14.55 & 14.65 & 14.60 & 1.35 & 1.59 & 1.47 & 72.89 & 73.91 & 73.40 & 1.46 & 1.74 & 1.60 & 74.87 & 441 & 442 & 442 & 0.02 & 504 & 11.0 & 10.07 \\
\hline & II & 13.55 & 13.76 & 13.66 & 1.6 & 1.75 & 1.68 & 67.36 & 68.1 & 67.73 & 1.17 & 1.35 & 1.26 & 69.41 & 442 & 443 & 443 & 0.02 & 500 & 9.2 & 12.27 \\
\hline & III & 10.9 & 11.26 & 11.08 & 1.67 & 1.89 & 1.78 & 53.43 & 53.23 & 53.33 & 0.74 & 0.97 & 0.86 & 55.11 & 442 & 443 & 443 & 0.03 & 489 & 7.7 & 16.06 \\
\hline & IV & 9.7 & 9.99 & 9.85 & 2.23 & 2.41 & 2.32 & 35.94 & 36.19 & 36.07 & 0.52 & 0.65 & 0.59 & 38.39 & 443 & 445 & 444 & 0.06 & 372 & 5.9 & 23.57 \\
\hline & V & 8.01 & 8.15 & 8.08 & 1.96 & 2.03 & 2.00 & 20.29 & 19.87 & 20.08 & 0.68 & 0.83 & 0.76 & 22.08 & 446 & 447 & 447 & 0.09 & 251 & 9.3 & 24.69 \\
\hline & VI & 6.89 & 7.01 & 6.95 & 1.13 & 1.25 & 1.19 & 3.25 & 3.51 & 3.38 & 0.75 & 0.71 & 0.73 & 4.57 & 564 & 571 & 568 & 0.26 & 49 & 10.5 & 17.12 \\
\hline & VII & 6.73 & 6.75 & 6.74 & 0.76 & 0.82 & 0.79 & 2.2 & 1.9 & 2.05 & 0.62 & 0.58 & 0.60 & 2.84 & 584 & 589 & 587 & 0.28 & 30 & 8.9 & 11.72 \\
\hline & VIII & 6.65 & 6.53 & 6.59 & 0.38 & 0.45 & 0.42 & 1.05 & 1.15 & 1.10 & 0.43 & 0.5 & 0.47 & 1.52 & 600 & 612 & 606 & 0.27 & 17 & 7.1 & 6.30 \\
\hline \multirow{3}{*}{\multicolumn{2}{|c|}{ Meihe Basin }} & & TOC & & & $\mathrm{S} 1$ & & & $\mathrm{~S} 2$ & & & S3 & & $\mathrm{S} 1+\mathrm{S} 2$ & & Tmax & & \multirow{3}{*}{ PI } & $\mathrm{HI}$ & OI & \multirow{3}{*}{ OSI } \\
\hline & & & (wt.\%) & & \multicolumn{10}{|c|}{$(\mathrm{mg} / \mathrm{g})$} & \multicolumn{3}{|c|}{$\left({ }^{\circ} \mathrm{C}\right)$} & & $(\mathrm{mg}$ & (OC) & \\
\hline & & 1 & 2 & av. & 1 & 2 & av. & 1 & 2 & av. & 1 & 2 & av. & av. & 1 & 2 & av. & & & & \\
\hline \multicolumn{2}{|c|}{ OS } & 25.73 & 25.19 & 25.46 & 0.85 & 1.12 & 0.99 & 100.42 & 99.23 & 99.83 & 6.09 & 5.96 & 6.03 & 100.81 & 426 & 428 & 427 & 0.01 & 388 & 23.7 & 3.87 \\
\hline \multirow{8}{*}{ 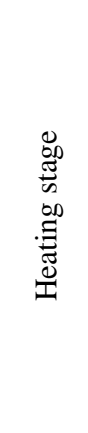 } & I & 25.91 & 25.67 & 25.79 & 1.07 & 1.15 & 1.11 & 99.86 & 101.27 & 100.26 & 2.61 & 3.01 & 2.81 & 101.37 & 432 & 431 & 432 & 0.01 & 387 & 10.9 & 4.30 \\
\hline & II & 25.1 & 25.02 & 25.06 & 1.79 & 1.83 & 1.81 & 95.39 & 96.17 & 95.78 & 2.73 & 3.05 & 2.89 & 97.59 & 436 & 437 & 437 & 0.02 & 382 & 11.5 & 7.22 \\
\hline & III & 24.63 & 24.57 & 24.60 & 2.87 & 3.01 & 2.94 & 83.29 & 82.59 & 82.94 & 2.41 & 3.12 & 2.77 & 85.88 & 439 & 440 & 440 & 0.03 & 337 & 11.2 & 11.95 \\
\hline & IV & 23.8 & 23.7 & 23.75 & 3.63 & 3.59 & 3.61 & 65.83 & 66.73 & 66.28 & 3.07 & 3.56 & 3.32 & 69.89 & 442 & 443 & 443 & 0.05 & 278 & 14.0 & 15.20 \\
\hline & $\mathrm{V}$ & 20.13 & 19.67 & 19.90 & 2.21 & 2.4 & 2.31 & 33.17 & 32.54 & 32.86 & 3.15 & 3.48 & 3.32 & 35.16 & 448 & 448 & 448 & 0.07 & 163 & 16.7 & 11.58 \\
\hline & VI & 17.91 & 17.56 & 17.74 & 0.95 & 1.02 & 0.99 & 4.21 & 5.01 & 4.61 & 1.91 & 1.88 & 1.90 & 5.60 & 534 & 536 & 535 & 0.18 & 26 & 10.7 & 5.55 \\
\hline & VII & 17.4 & 17.35 & 17.38 & 0.89 & 0.86 & 0.88 & 1.8 & 2.03 & 1.92 & 1.68 & 1.91 & 1.80 & 2.79 & 598 & 602 & 600 & 0.31 & 11 & 10.3 & 5.04 \\
\hline & VIII & 17.23 & 16.83 & 17.03 & 0.56 & 0.49 & 0.53 & 1.35 & 0.95 & 1.15 & 2.53 & 2.67 & 2.60 & 1.68 & 610 & 615 & 613 & 0.31 & 7 & 15.3 & 3.08 \\
\hline
\end{tabular}


Table 4. Ro values of the oil shale samples after the different heating steps.

\begin{tabular}{ccccccccc}
\hline \multirow{2}{*}{$\begin{array}{c}\text { Heating } \\
\text { stage }\end{array}$} & Heating & Statistical & \multicolumn{9}{c}{ Ro $(\%)$} & Standard \\
\cline { 4 - 7 } temperature & number & avg. & $\max$ & $\min$ & Error $(+)$ & Error (-) & Dev. $(\%)$ \\
\hline Os & Rt & 103 & 0.396 & 0.439 & 0.363 & 0.043 & 0.033 & 0.016 \\
I & Rt $-185^{\circ} \mathrm{C}$ & 121 & 0.496 & 0.534 & 0.451 & 0.038 & 0.045 & 0.020 \\
II & $185^{\circ} \mathrm{C}-300^{\circ} \mathrm{C}$ & 116 & 0.629 & 0.714 & 0.557 & 0.085 & 0.072 & 0.036 \\
III & $300^{\circ} \mathrm{C}-350^{\circ} \mathrm{C}$ & 136 & 0.737 & 0.821 & 0.671 & 0.084 & 0.066 & 0.035 \\
IV & $350^{\circ} \mathrm{C}-400^{\circ} \mathrm{C}$ & 119 & 0.779 & 0.878 & 0.701 & 0.099 & 0.078 & 0.037 \\
V & $400^{\circ} \mathrm{C}-440^{\circ} \mathrm{C}$ & 114 & 0.869 & 0.957 & 0.74 & 0.088 & 0.129 & 0.053 \\
VI & $440^{\circ} \mathrm{C}-475^{\circ} \mathrm{C}$ & 133 & 1.360 & 1.443 & 1.214 & 0.083 & 0.146 & 0.045 \\
VII & $475^{\circ} \mathrm{C}-500^{\circ} \mathrm{C}$ & 141 & 1.488 & 1.598 & 1.351 & 0.110 & 0.137 & 0.057 \\
VIII & $500^{\circ} \mathrm{C}-520^{\circ} \mathrm{C}$ & 123 & 1.593 & 1.741 & 1.414 & 0.148 & 0.179 & 0.059 \\
\hline
\end{tabular}


Click here to download high resolution image

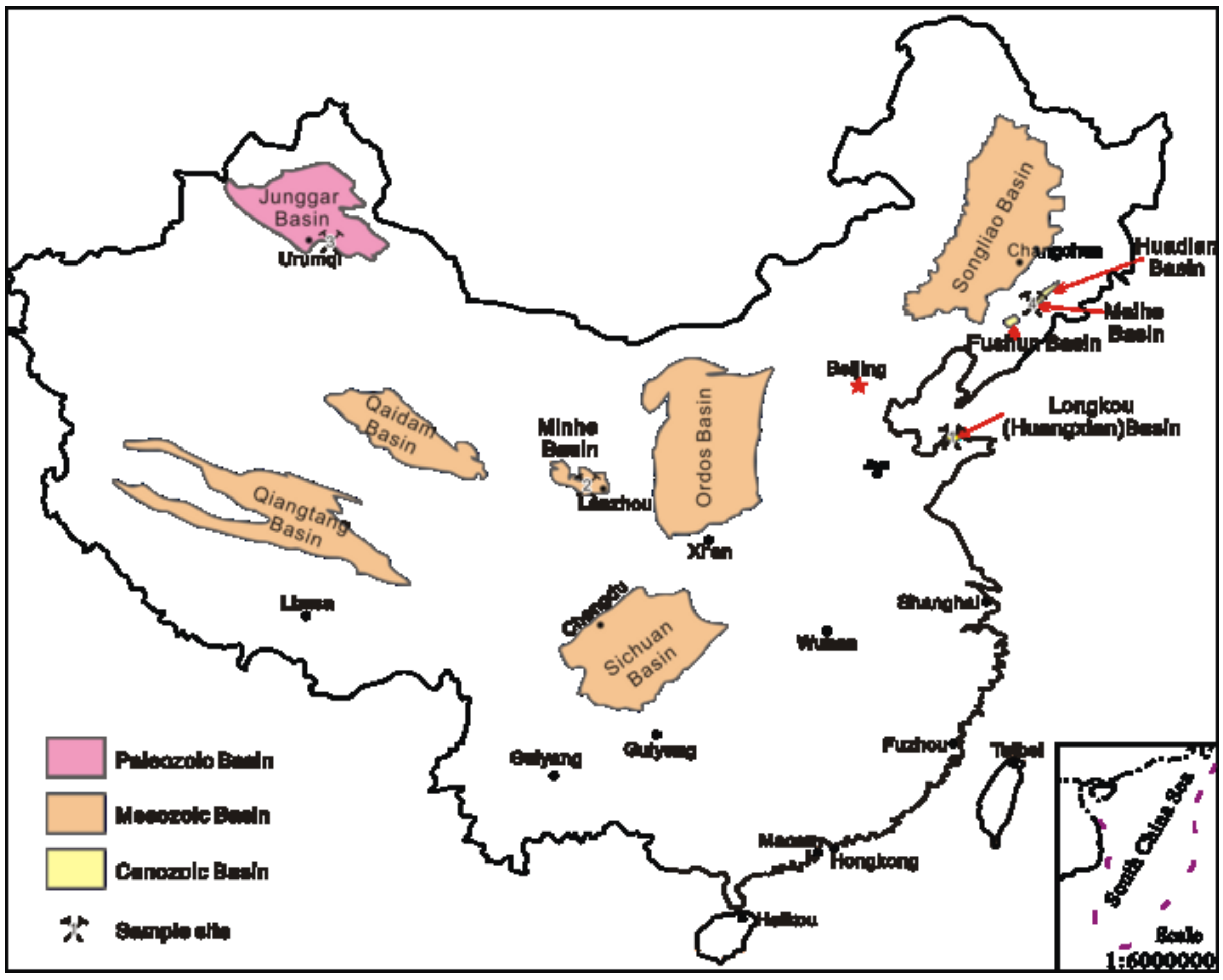




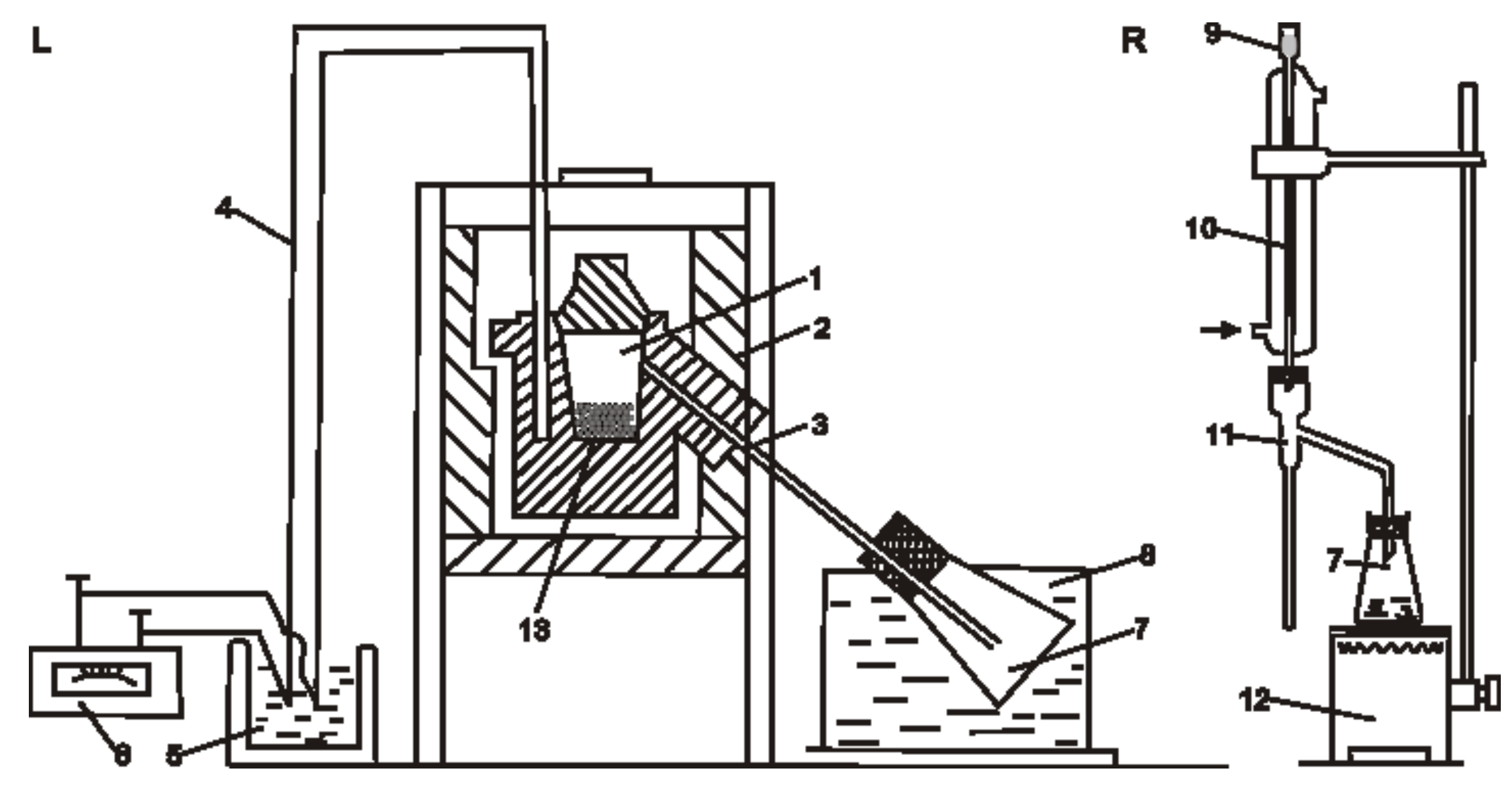



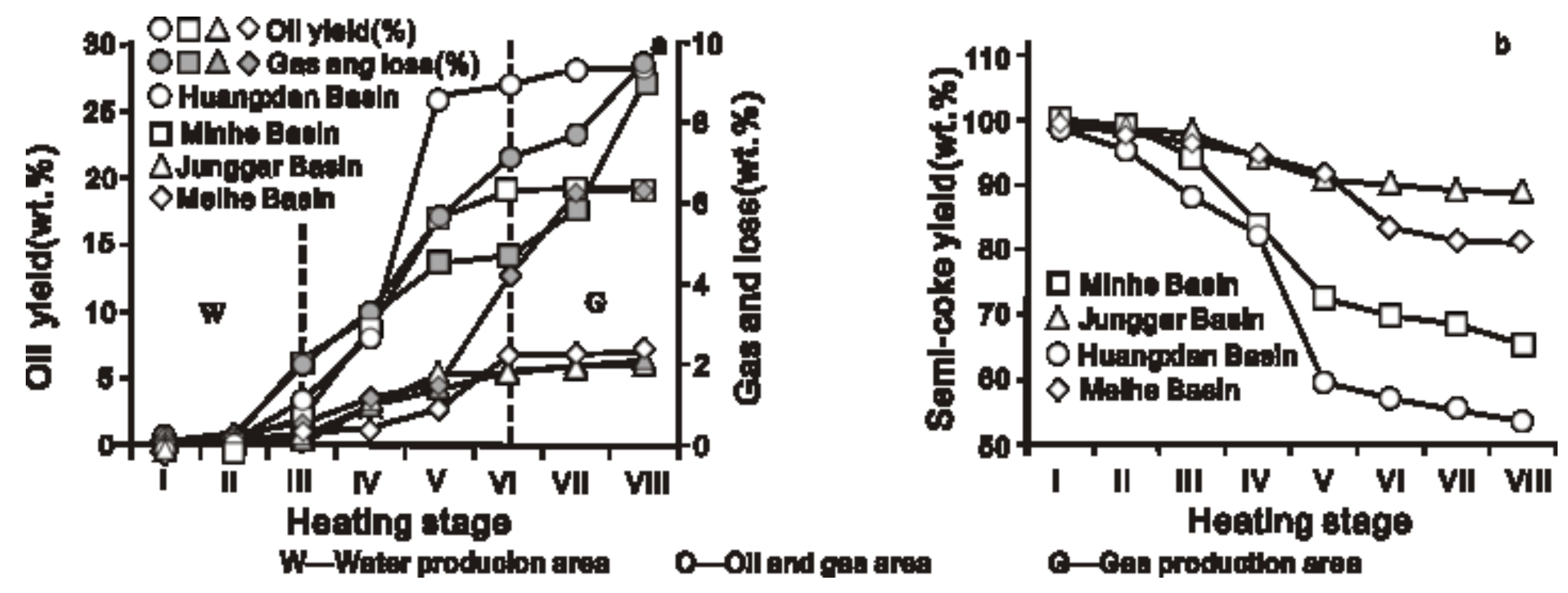

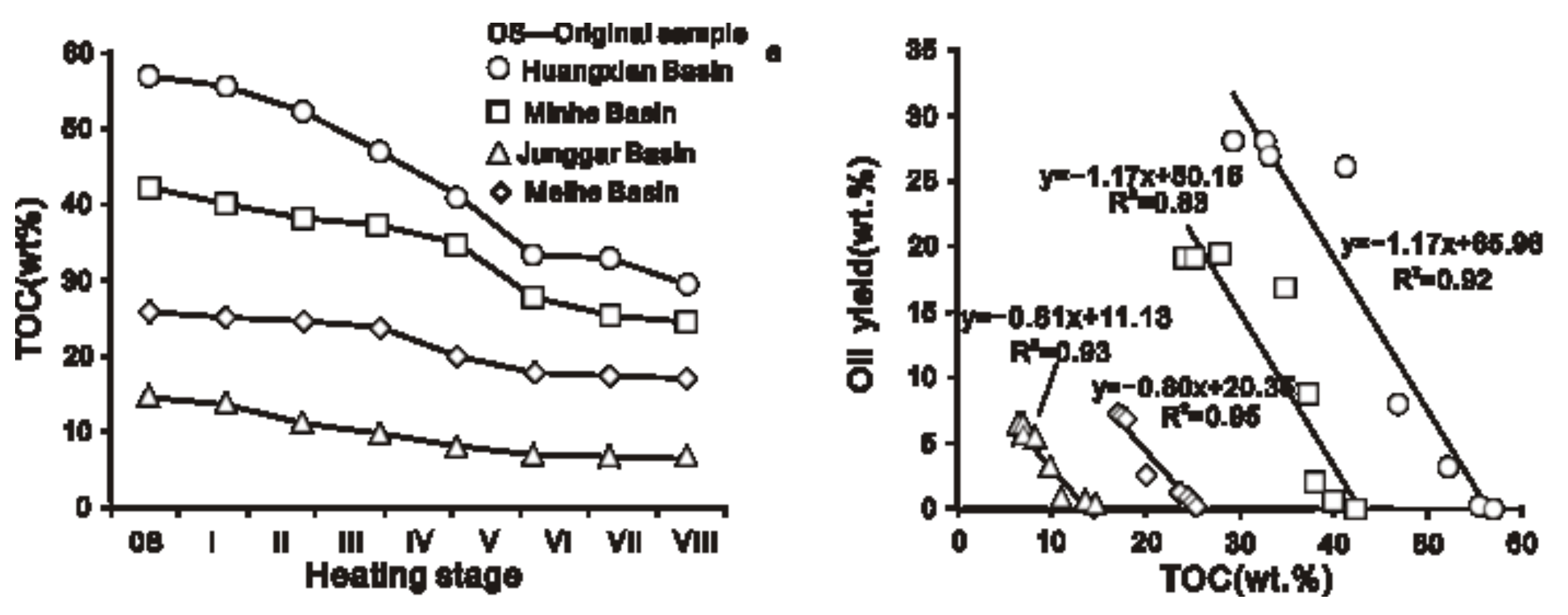


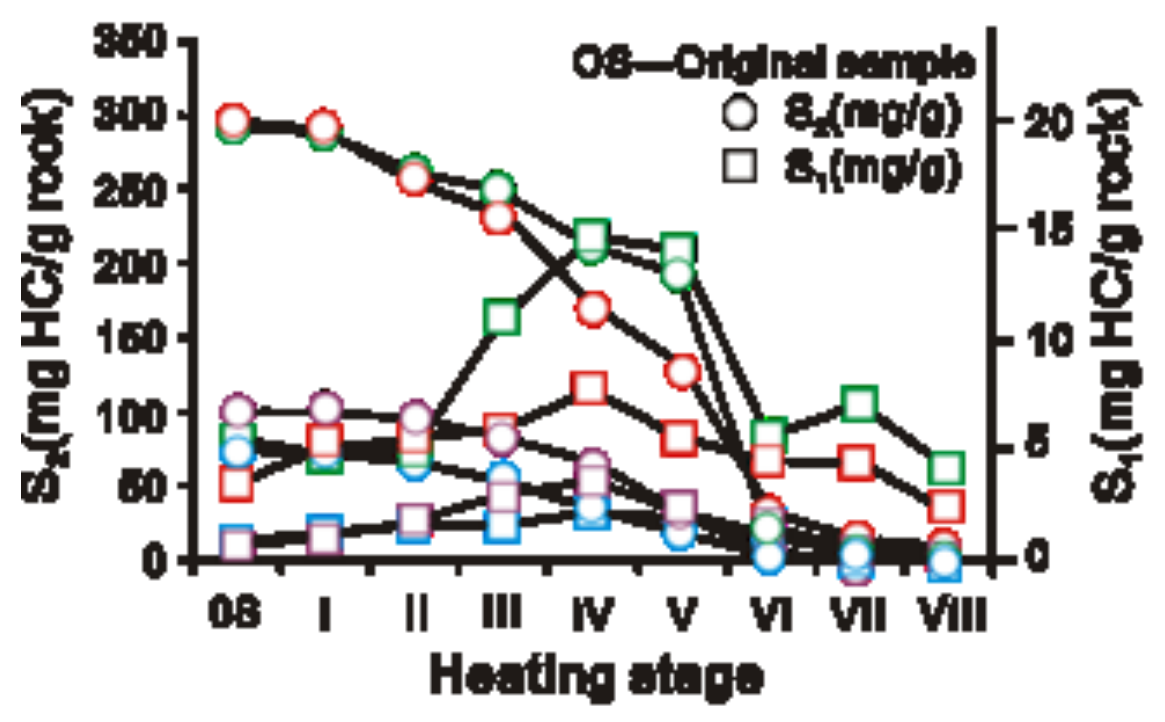

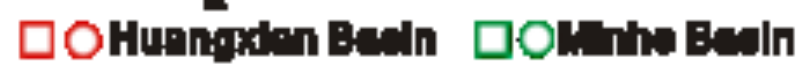

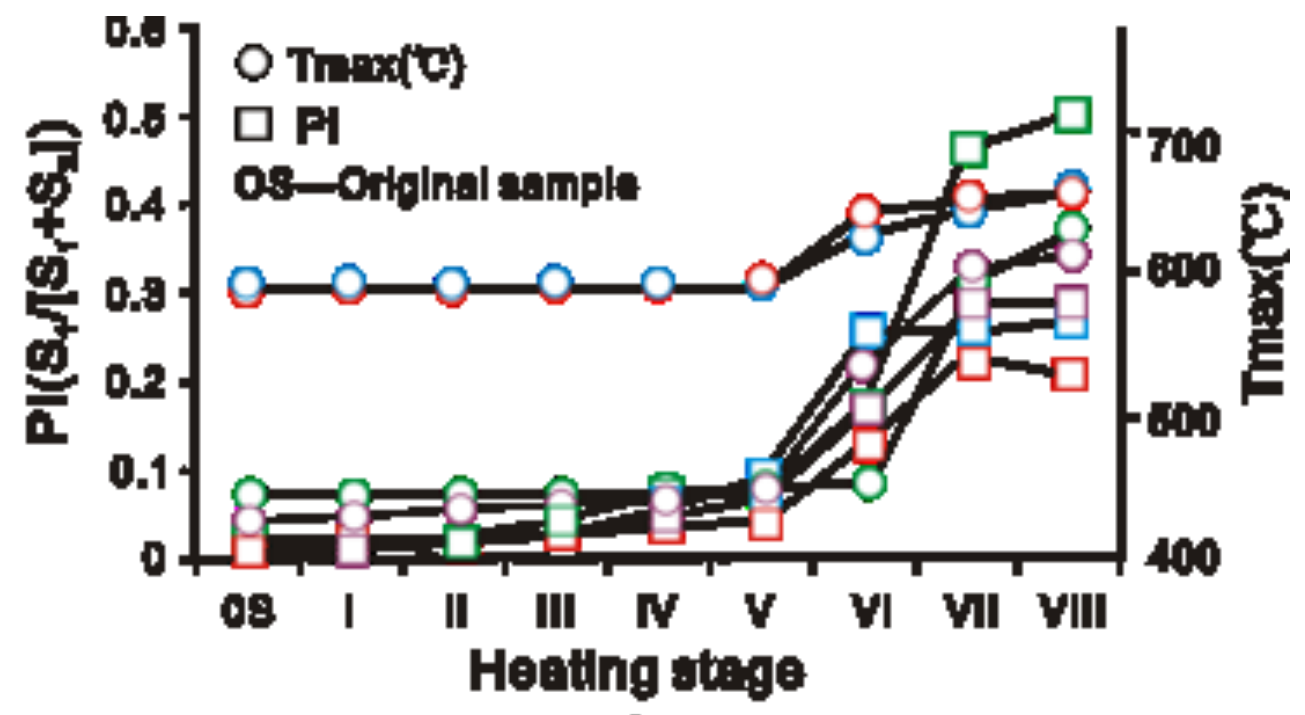

b

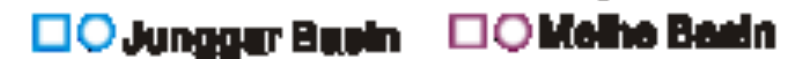




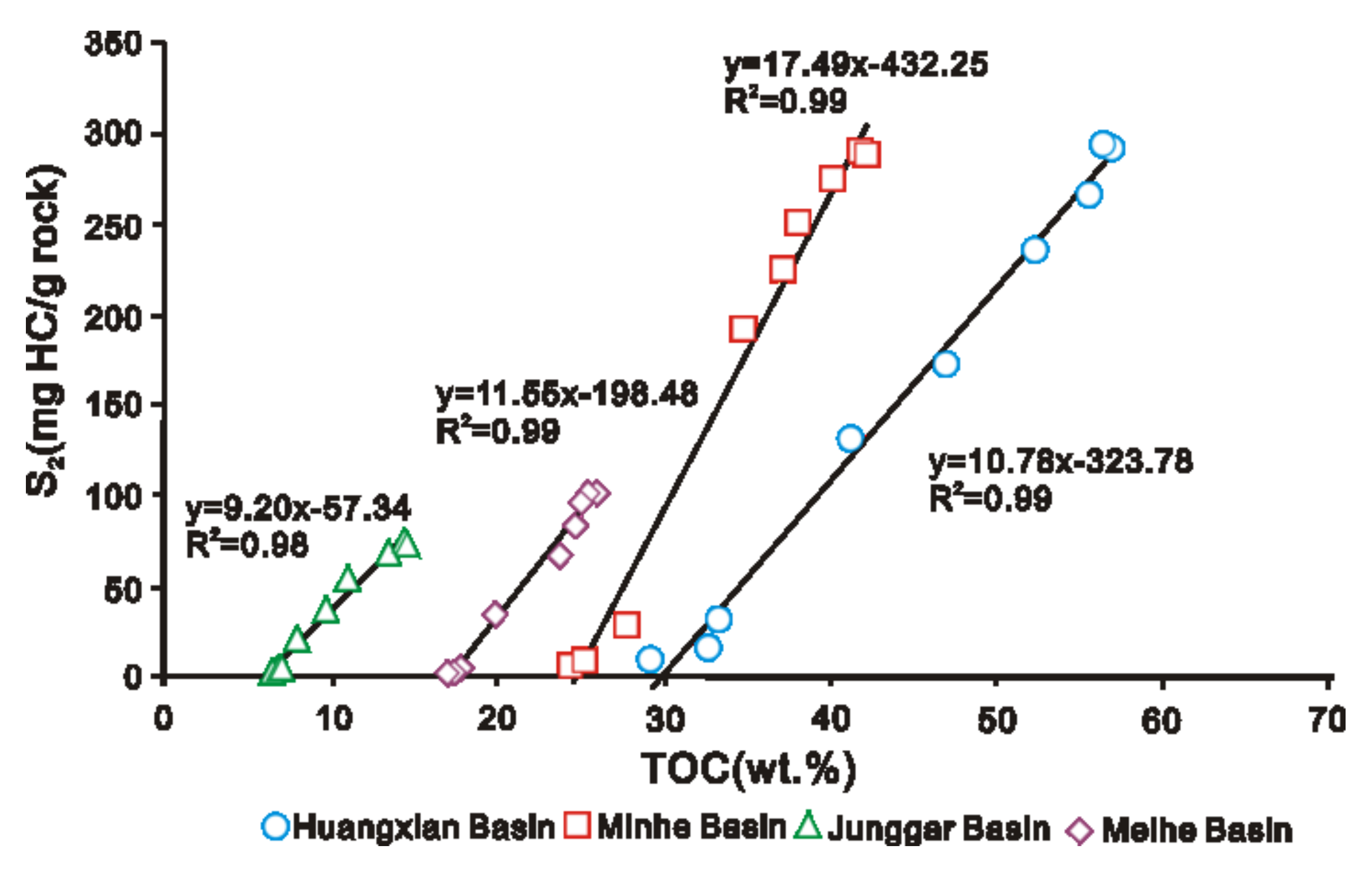

OHuangxlan Basin $\square$ MInhe Besin $\triangle$ Jungger Basin $\diamond$ Melhe Basin OHuangxlan Basin $\square$ MInhe Begin $\triangle$ Junggar Basin $\diamond$ Molho Basin 


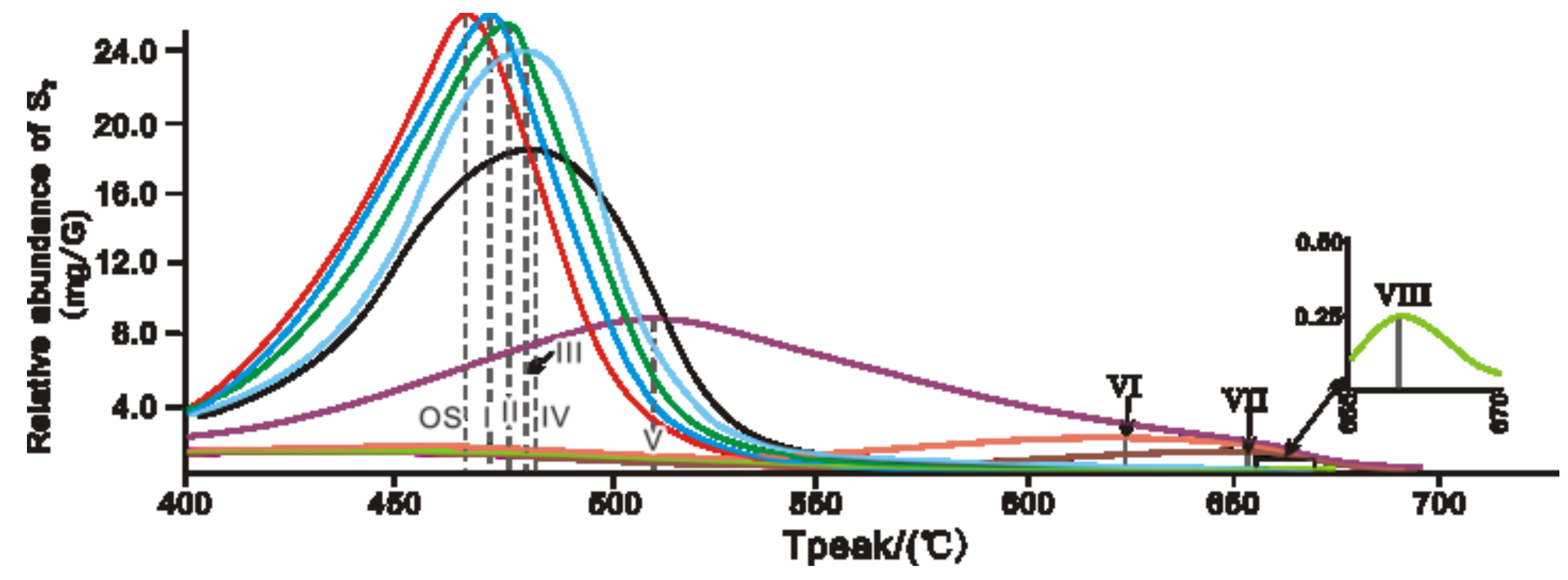


Figure8

Click here to download high resolution image

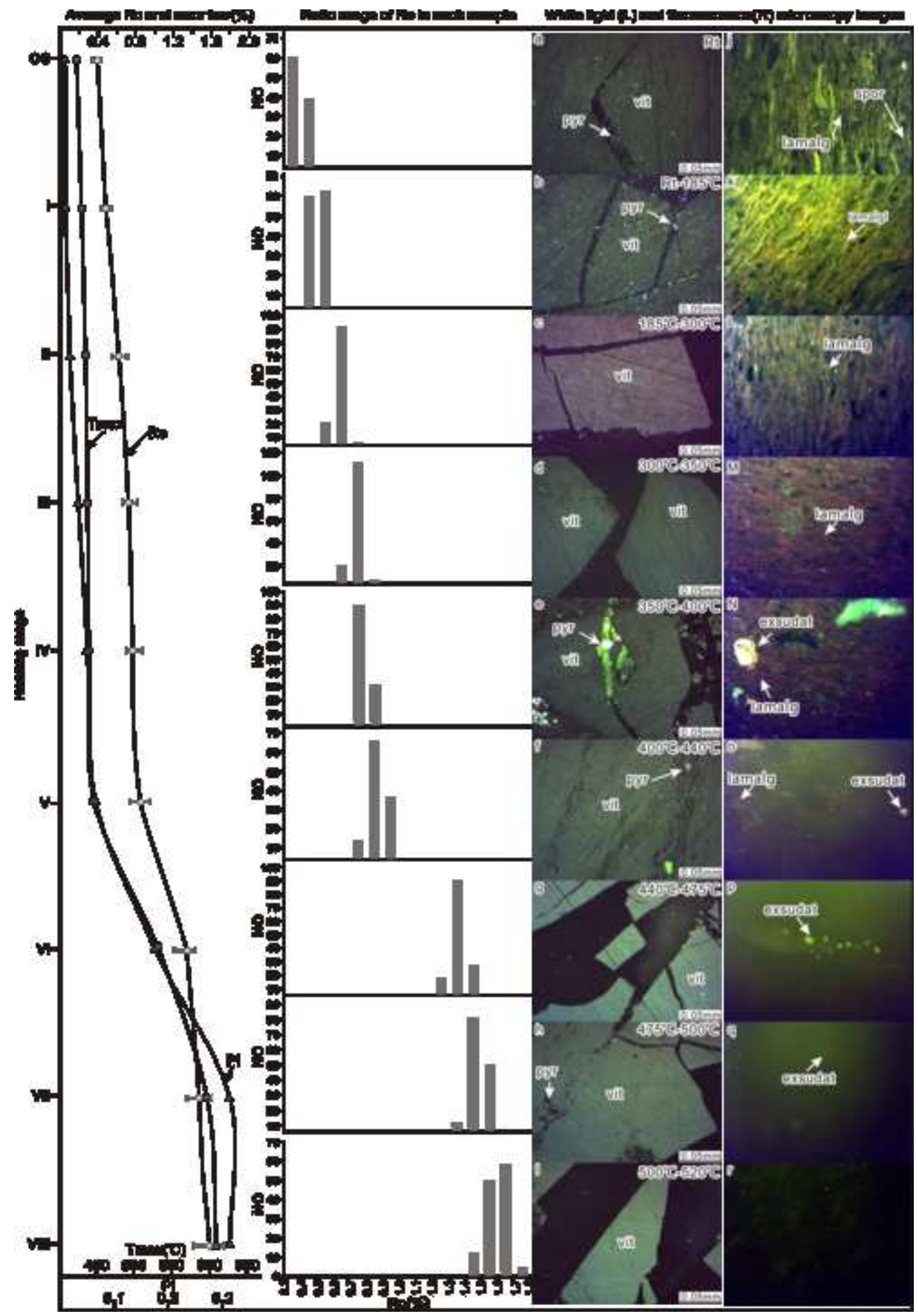



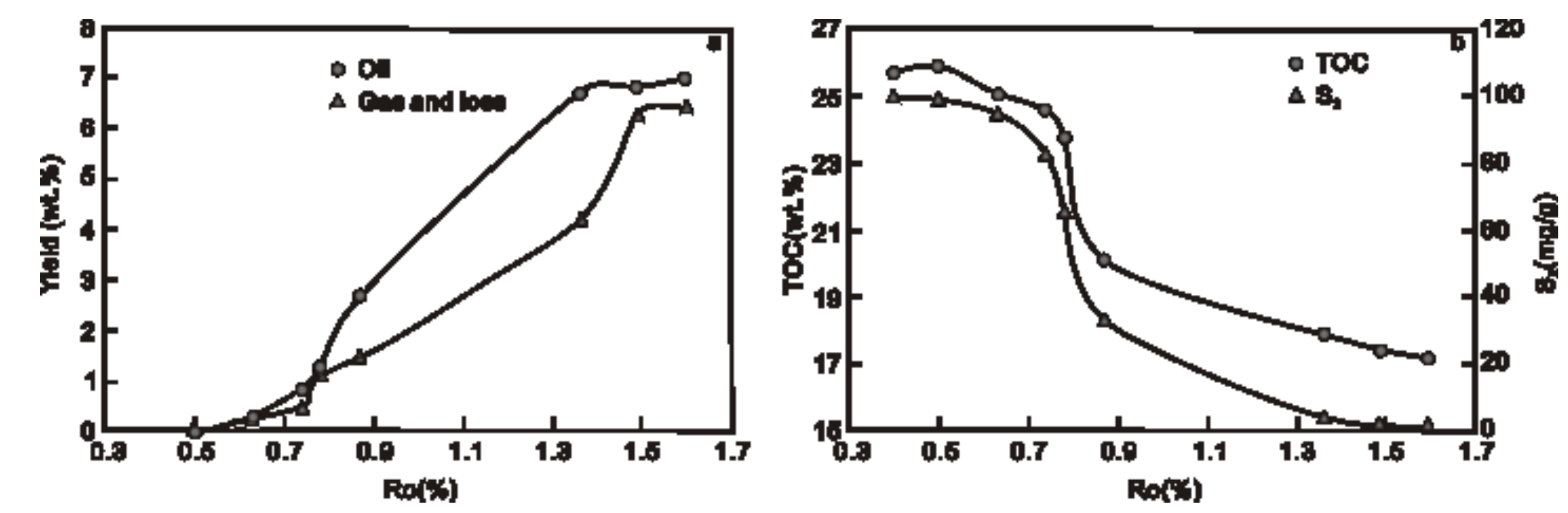

here to download high resolution image 


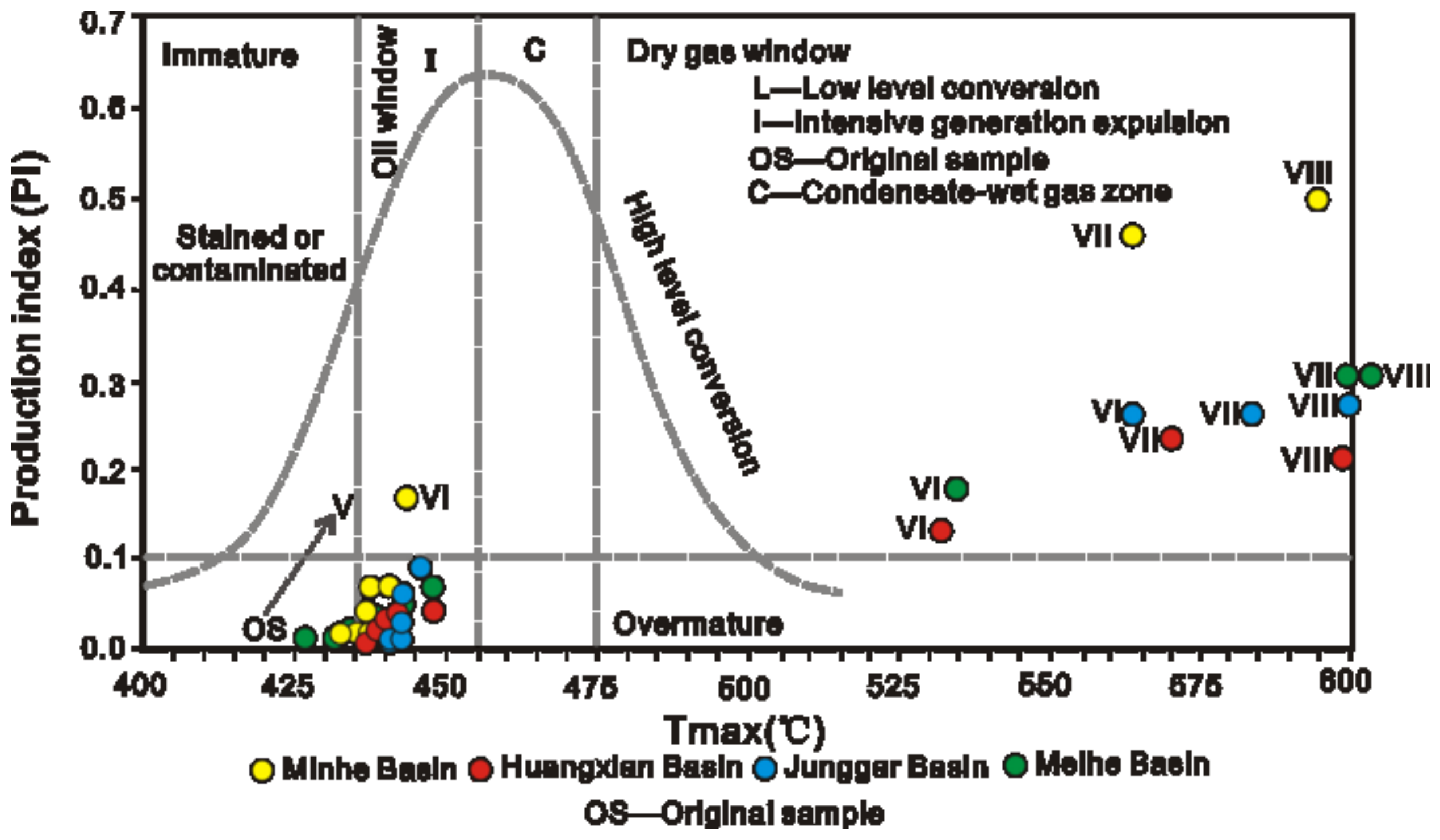




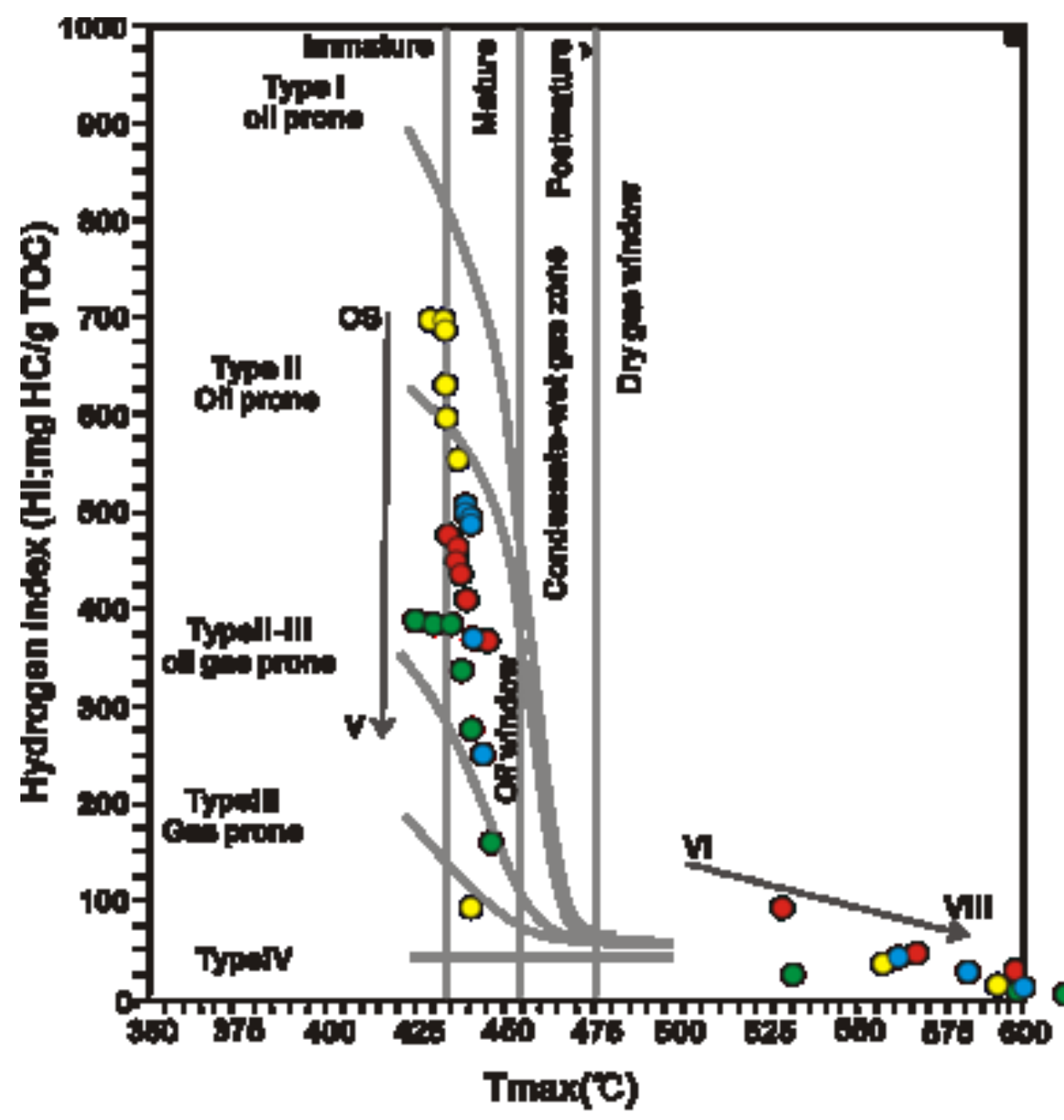

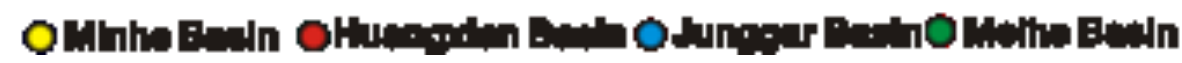

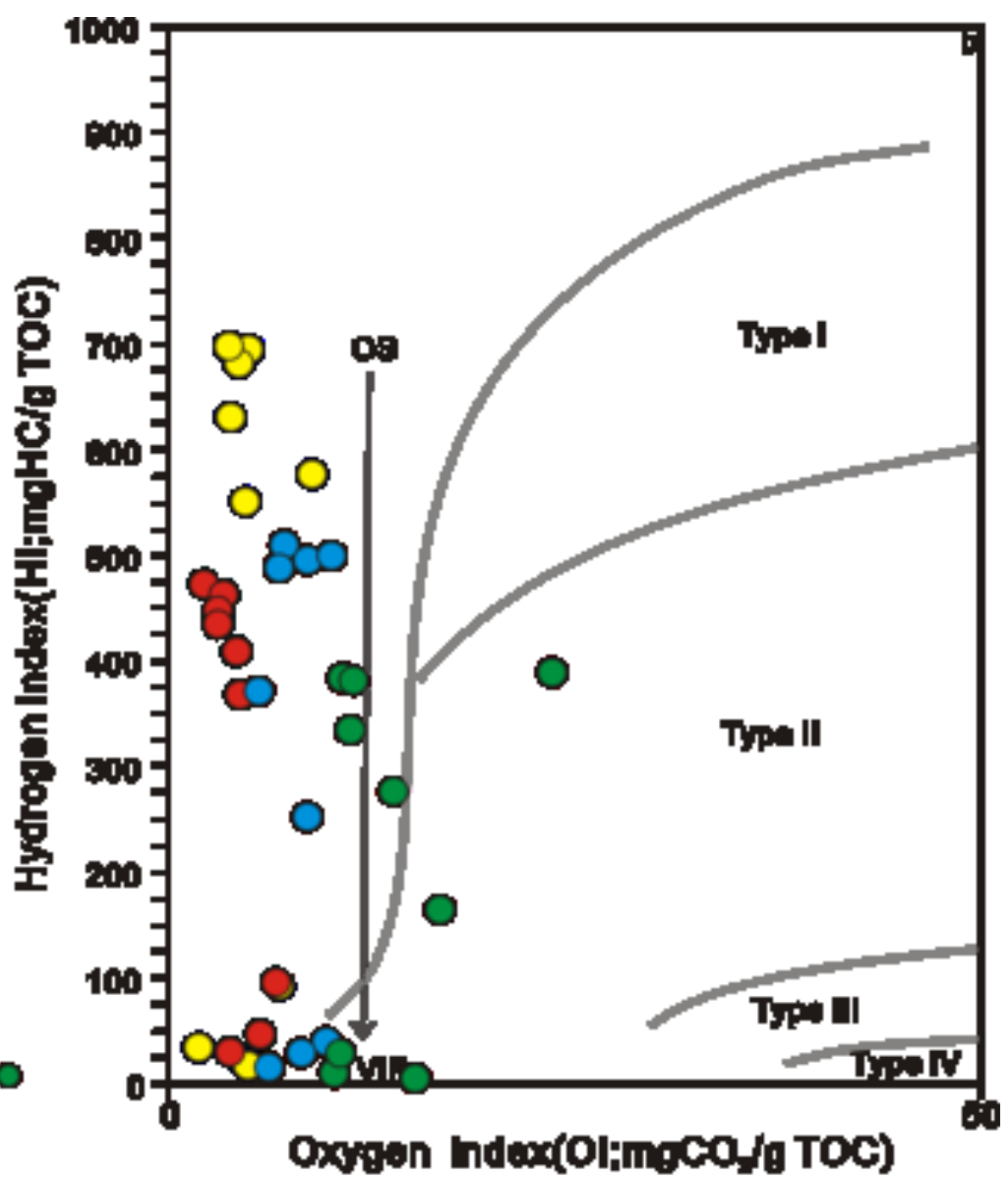

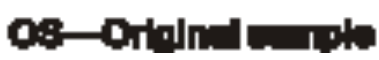



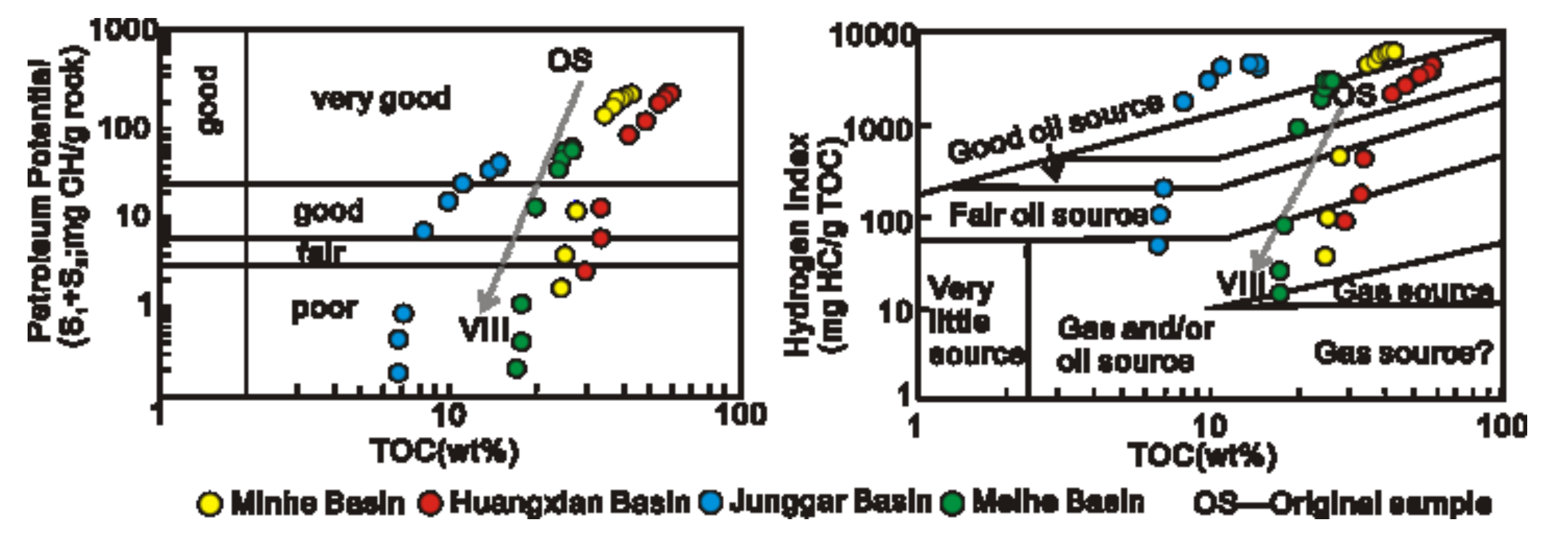

O Mlnhe Besin O Huangxan Basin O Junggar Basin O Melhe Baoln Os-Oripinel oumple

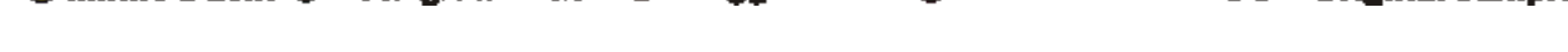

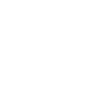


Proportion of generated/expuleed/retelned hydrocarbon

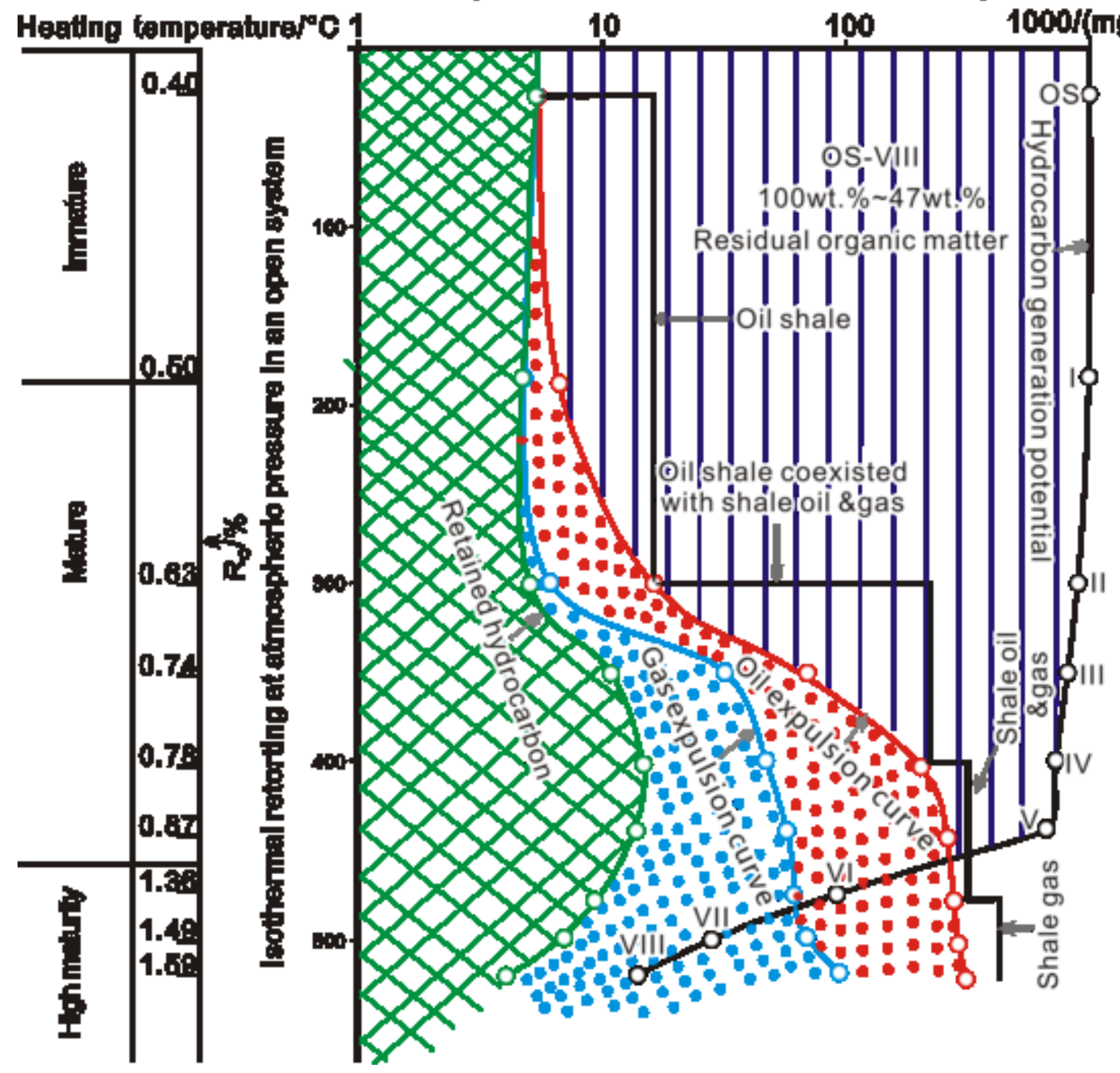

